Andrews University

Digital Commons @ Andrews University

\title{
"Our Families for God": a Family Worship Seminar for the Hamilton Mountain Seventh-day Adventist Church
}

Wesley Rocha Torres

Andrews University

Follow this and additional works at: https://digitalcommons.andrews.edu/dmin

Part of the Practical Theology Commons

\section{Recommended Citation}

Torres, Wesley Rocha, "'Our Families for God": a Family Worship Seminar for the Hamilton Mountain Seventh-day Adventist Church" (2007). Professional Dissertations DMin. 451.

https://dx.doi.org/10.32597/dmin/451

https://digitalcommons.andrews.edu/dmin/451

This Project Report is brought to you for free and open access by the Graduate Research at Digital Commons @ Andrews University. It has been accepted for inclusion in Professional Dissertations DMin by an authorized administrator of Digital Commons @ Andrews University. For more information, please contact repository@andrews.edu. 


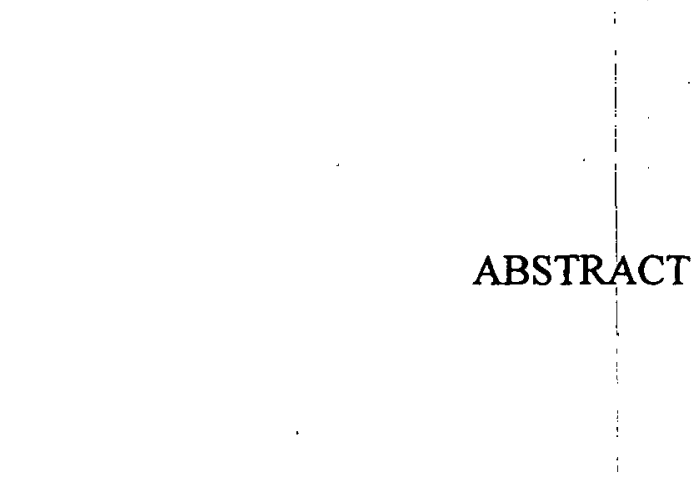

“OUR FAMILIES FOR GOD”-A FAMILY WORSHIP SEMINAR FOR THE HAMILTON MOUNTAIN SEVENTH-

DAY ADVENTIST CHURCH

by

Wesley Rocha Torres

Adviser: Alfonso Valenzuela 


\section{ABSTRACT OF GRADUATE STUDENT RESEARCH}

\section{Dissertation}

Andrews University

Seventh-day Adventist Theological Seminary

Title: "OUR FAMILIES FOR GOD"-A FAMILY WORSHIP SEMINAR FOR THE HAMILTON MOUNTAIN SEVENTH-DAY ADVENTIST CHURCH

Name of researcher: Wesley Rocha Torres

Faculty Advisor: Alfonso Valenzuela, Ph.D.

Date completed: July 2007

\section{Problem}

Family worship is highly esteemed by the members of the Hamilton Mountain Seventh-day Adventist Church, yet the quality and practice of this spiritual activity could still be improved among the church families. It was the researcher's presupposition that the design of a practical, creative, and attractive family worship seminar, incorporating new ideas and suggestions, could motivate and assist the church members to enhance their spiritual experience and fellowship with God, as well as within their family circles.

\section{Method}

The topic of family worship was brought to the church through a series of sermons and also the children's story segment of the Divine Service. Then, a 
questionnaire was developed in order to collect information from the active members of the church, in relation to their awareness and involvement with the practice of family worship. In that instrument, members were offered the opportunity to present their expectations, as well as make suggestions related to the family worship seminar which would be developed at a later stage of the research. This seminar would also be evaluated by the church members in order to measure its effectiveness. Aspects to be assessed would include both the content and presentation.

\section{Results}

One hundred and eighty two members returned the questionnaire, which provided a return rate of slightly over 60 percent of possible responses. Subsequently, the seminar was evaluated by 179 individuals, reaching a quotient of nearly 60 percent when compared to the number of those who were originally mailed the family worship questionnaire (301).. Overall, the evaluation form showed that the seminar attracted the interest of the members and made them aware about the importance of the practice of this spiritual activity in their families. It also reached the goal of introducing new and creative ideas for the practice of family worship. There was an increase of 40 active participants (179 responses) during the seminar, or nearly 29 percent, when compared with the initial number of members who initially indicated previous association with or participation in family worship (139).

\section{Conclusions}

The involvement and participation of the congregation during the different stages of this endeavor, which climaxed with the development and presentation of the family 
worship seminar, was one of the highlights of this project. It clearly demonstrated the interest of members and their families in the subject and that their level of awareness about the spiritual relevancy of the topic reached the proposed goal.

The seminar was ranked highly by appreciative church members when it was evaluated on its structure, language, content, creativity, new ideas and suggestions, challenge for parents, interest of children, etc. Conversely, the evaluation form also revealed some concerns regarding the length of the seminar. It appears that when this seminar is presented in the future, serious consideration should be given to spreading the presentation over more than one day. 
Andrews University

Seventh-day Adventist Theological Seminary

"OUR FAMILIES FOR GOD"-A FAMILY WORSHIP SEMINAR FOR THE HAMILTON MOUNTAIN SEVENTH-DAY

ADVENTIST CHURCH

\author{
A Dissertation \\ Presented in Partial Fulfillment \\ of the Requirements for the Degree \\ Doctor of Ministry
}

by

Wesley Rocha Torres

July 2007 

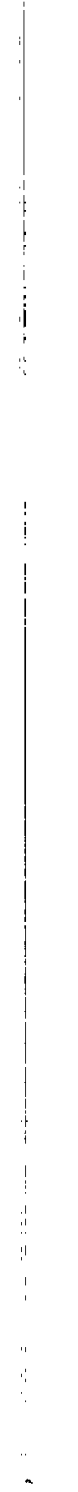


\title{
"OUR FAMILIES FOR GOD"-A FAMILY WORSHIP SEMINAR FOR THE HAMILTON MOUNTAIN SEVENTH-DAY \\ ADVENTIST CHURCH
}

\author{
A dissertation \\ presented in partial fulfillment \\ of the requirements for the degree \\ Doctor of Ministry
}

by

Wesley Rocha Torres

APPROVAL BY THE COMMITTEE:

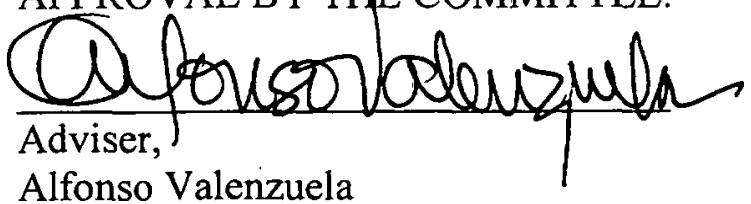

Alfonso Valenzuela

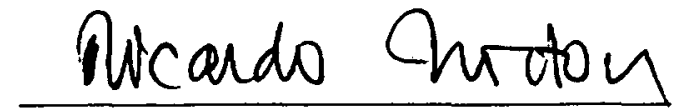

Ricardo Norton

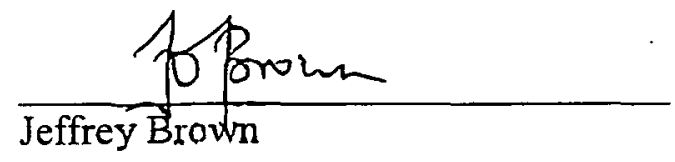

Director of D.Min. Program

Skip Bell

Penis toot:

Dean, SDA Theologica/ Seminary

Denis Fortin

June 29,2007

Date approved 


\section{TABLE OF CONTENTS}

LIST OF TABLES $\ldots \ldots \ldots \ldots \ldots \ldots \ldots \ldots \ldots \ldots \ldots \ldots \ldots \ldots \ldots \ldots \ldots \ldots$ vi

LIST OF FIGURES $\ldots \ldots \ldots \ldots \ldots \ldots \ldots \ldots \ldots \ldots \ldots \ldots \ldots \ldots \ldots \ldots \ldots \ldots$

ACKNOWLEDGMENTS $\ldots \ldots \ldots \ldots \ldots \ldots \ldots \ldots \ldots \ldots \ldots \ldots \ldots \ldots \ldots$ ix

Chapter

I. INTRODUCTION $\ldots \ldots \ldots \ldots \ldots \ldots \ldots \ldots \ldots \ldots \ldots \ldots \ldots \ldots \ldots \ldots$

Statement of the Problem $\ldots \ldots \ldots \ldots \ldots \ldots \ldots \ldots \ldots \ldots$

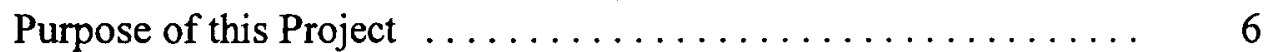

Theoretical Rationale ........................ 6

Importance of the Study $\ldots \ldots \ldots \ldots \ldots \ldots \ldots \ldots \ldots, 9$

Definitions of Terms ....................... 9

Assumption of the Study $\ldots \ldots \ldots \ldots \ldots \ldots \ldots \ldots \ldots, 11$

Delimitations and Limitations of the Study $\ldots \ldots \ldots \ldots \ldots \ldots .11$

General Overview of the Dissertation $\ldots \ldots \ldots \ldots \ldots \ldots \ldots .13$

II. FOUNDATIONS ON FAMILY WORSHIP $\ldots \ldots \ldots \ldots \ldots \ldots \ldots$

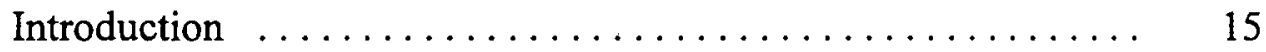

The Controversy about Worship $\ldots \ldots \ldots \ldots \ldots \ldots \ldots . \ldots \ldots$

Defining Worship .......................... 18

Worship Is a Celebration $\ldots \ldots \ldots \ldots \ldots \ldots \ldots \ldots . \quad 19$

Reason for Worship .................... 20

The Family and Worship $\ldots \ldots \ldots \ldots \ldots \ldots \ldots \ldots .21$

The Goal of the Christian Family ............... 22

The Battle over the Family ................. 25

Reason for Family Worship $\ldots \ldots \ldots \ldots \ldots \ldots \ldots \ldots .26$

Purposes of Family Worship $\ldots \ldots \ldots \ldots \ldots \ldots \ldots \ldots .28$

Family Worship in the Old Testament ............... 30

Family Worship in the New Testament $\ldots \ldots \ldots \ldots \ldots \ldots . \quad 35$

Family Worship in Christian Literature $\ldots \ldots \ldots \ldots \ldots \ldots . \quad 37$

The First Christian Centuries $\ldots \ldots \ldots \ldots \ldots \ldots \ldots . \ldots \ldots$

During the Middle Ages ...................... 39

During the Reformers' Time $\ldots \ldots \ldots \ldots \ldots \ldots \ldots \ldots, 41$

The Influence of Puritanism in the New World ........ 47

Family Worship in the Writings of Ellen G. White ......... 50 


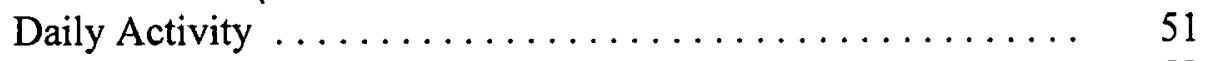

Structured Program ........................ 52

Parents' Responsibility ....................... $\quad 55$

The Father as a Priest $\ldots \ldots \ldots \ldots \ldots \ldots \ldots \ldots \ldots . \ldots \ldots$

Mother as the Queen of the Home ............. 57

The Role of the Church Pastor in Family Worship ......... 57

The Pastor as a Preacher in Relation to Family Worship ..... 58

The Pastor Needs to Preach about Family Worship ..... 58

Personal Testimonies .................. 59

Children's Story $\ldots \ldots \ldots \ldots \ldots \ldots \ldots \ldots \ldots .60$

Illustration ........................ 60

The Counselling Pastor and Family Worship $\ldots \ldots \ldots \ldots .61$

The Pastor as the Spiritual Leader ............... 62

Pastoral Visitation and Family Worship $\ldots \ldots \ldots \ldots \ldots .63$

The Ministry of Pastoral Visitation and Family Worship .... 63

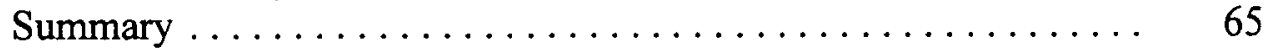

III. FAMILY WORSHIP AT THE HAMILTON MOUNTAIN

CHURCH $\ldots \ldots \ldots \ldots \ldots \ldots \ldots \ldots \ldots \ldots \ldots \ldots \ldots \ldots \ldots \ldots \ldots$

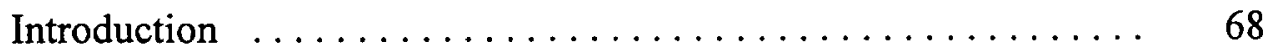

Demographics of the City of Hamilton $\ldots \ldots \ldots \ldots \ldots \ldots .68$

A History of the Hamilton Mountain SDA Church ....... 70

Population ................................ 74

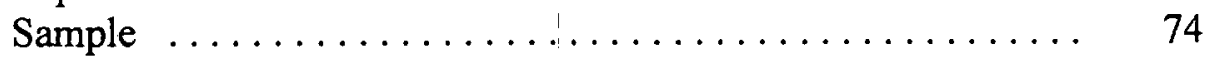

Instrument Development $\ldots \ldots \ldots \ldots \ldots \ldots \ldots \ldots \ldots$

Rationale of the Questionnaire and the Final Evaluation Survey . . 80

Methodology ........................... 83

Analysis of the Survey $\ldots \ldots \ldots \ldots \ldots \ldots \ldots \ldots \ldots$

IV. HAMILTON MOUNTAIN CHURCH FAMILY WORSHIP

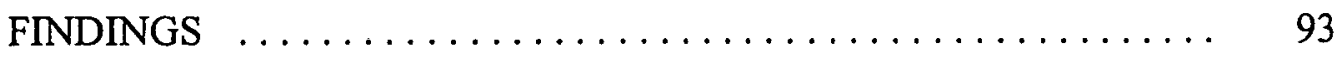

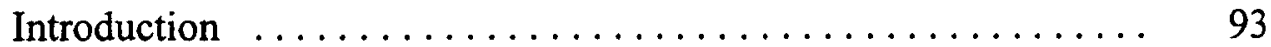

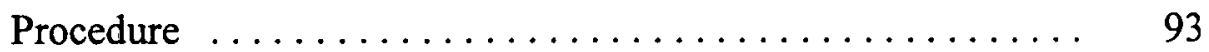

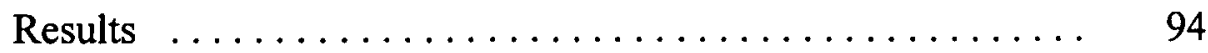

Family Worship with Children $\ldots \ldots \ldots \ldots \ldots \ldots \ldots, 111$

V. "OUR FAMILIES FOR GOD" SEMINAR $\ldots \ldots \ldots \ldots \ldots \ldots \ldots, 122$

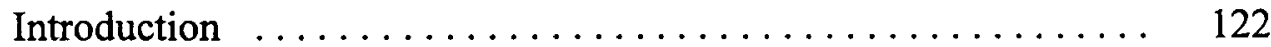

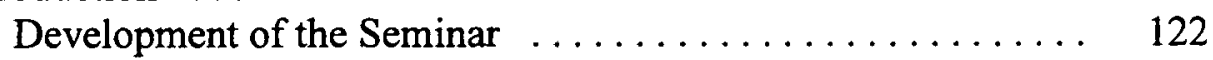

Description of the Seminar ................... 124

The First Session-The "Why" of Family Worship ..... 125

The Second Session-The "How" of Family Worship ... 125

The Third Session-The Benefits of Family Worship .... 126 
The Fourth Session-Family Worship with Children

(The When \& Where) $\ldots \ldots \ldots \ldots \ldots \ldots \ldots \ldots, 126$

Dialoguing with the Participants $\ldots \ldots \ldots \ldots \ldots \ldots \ldots . \ldots \ldots$

The Implementation of the Seminar . . . . . . . . . . . 127

Schedule of the Implementation Phase $\ldots \ldots \ldots \ldots \ldots, 128$

Length and Contents of the Seminar ............. 129

Schedule of the Sessions of the Seminar ........... 130

The Evaluation of the Seminar . . . . . . . . . . . . 130

Results of the Final Evaluation Survey $\ldots \ldots \ldots \ldots \ldots \quad 131$

VI. SUMMARY, CONCLUSIONS AND RECOMMENDATIONS ..... 139

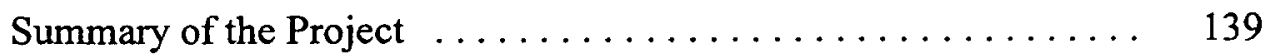

The Purpose of the Project $\ldots \ldots \ldots \ldots \ldots \ldots \ldots \ldots . \ldots \ldots$

The Problem ............................ 139

Review of Literature ...................... 140

Conclusion ........................... 142

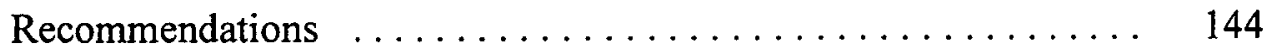

Appendix

A. Family Worship Questionnaire $\ldots \ldots \ldots \ldots \ldots \ldots \ldots \ldots \ldots \ldots$

B. Family Worship Seminar $\ldots \ldots \ldots \ldots \ldots \ldots \ldots \ldots \ldots \ldots \ldots \ldots$

C. Family Worship Seminar Work Sheet $\ldots \ldots \ldots \ldots \ldots \ldots \ldots \ldots 227$

BIBLIOGRAPHY ..................................... 248

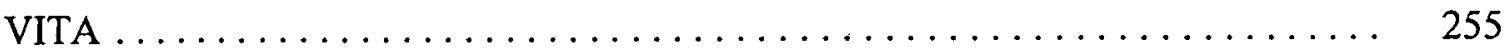




\section{LIST OF TABLES}

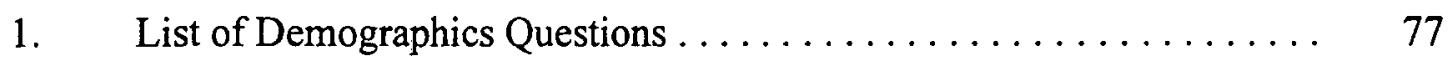

2. List of Questions Related to Family Worship Aims $\ldots \ldots \ldots \ldots \ldots .78$

3. List of Questions Related to Family Worship Attitudes .......... 79

4. List of Questions Related to Family Worship Methods .......... 80

5. Demographic Composition of the Sample $\ldots \ldots \ldots \ldots \ldots \ldots . . \ldots 5$

6. Practice of Family Worship $\ldots \ldots \ldots \ldots \ldots \ldots \ldots \ldots \ldots \ldots \ldots$

7. Adoption of Family Worship $\ldots \ldots \ldots \ldots \ldots \ldots \ldots \ldots \ldots . \ldots 9$

8. Most Relevant Factor of Family Worship $\ldots \ldots \ldots \ldots \ldots \ldots \ldots . \ldots$

9. Gender Vs. Length and Contents Factors of Family Worship ...... 109

10. Demographic Composition of Parents $\ldots \ldots \ldots \ldots \ldots \ldots \ldots \ldots, 112$

11. Children's Attitude to the Call for Family Worship .......... 112

12. Children's Enjoyment Vs. Length of Family Worship $\ldots \ldots \ldots \ldots \quad 113$

13. Children's Enjoyment Vs. Content and Length Factors ......... 114

14. Family Worship Weekly Preparation Time $\ldots \ldots \ldots \ldots \ldots \ldots . . \ldots$

15. Children's Involvement in Family Worship .............. 116

16. Active \& Inactive Children Vs. Family Worship Enjoyment $\ldots \ldots \quad 117$

17. Family Worship Preparation Time Vs. Children's Involvement .... 117 


\section{LIST OF FIGURES}

1. Formal Education Levels of the 139 Respondents $\ldots \ldots \ldots \ldots \ldots .98$

2. Set Time for Family Worship and Most Common Time for Family

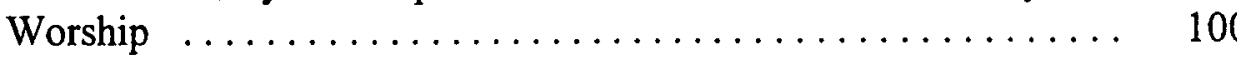

3. Family Worship and Personal Devotion $\ldots \ldots \ldots \ldots \ldots \ldots \ldots . \ldots 1$

4. Elements of Family Worship and Resources Used for Family

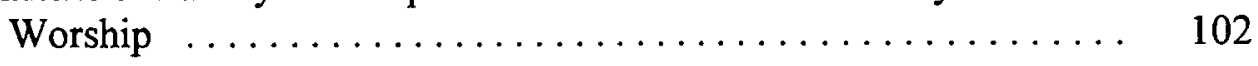

5. Members' Personal Evaluation of Their Family Worship $\ldots \ldots \ldots .103$

6. Members' Personal Evaluation-Presently Practicing Family

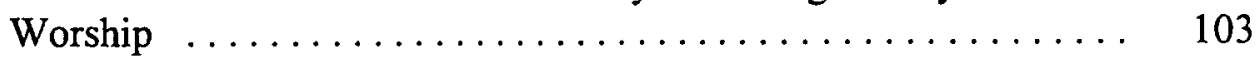

7. Members' Perceptions about How to Improve Their Family

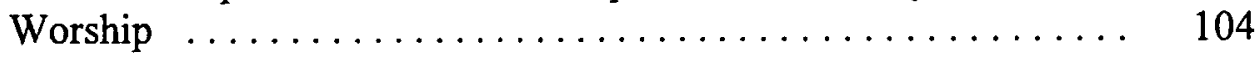

8. Most Important Elements of Family Worship as Judged by

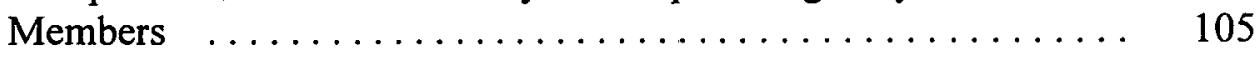

9. Members' Family Worship Average Length Percentage (\%) $\ldots \ldots .106$

10. Gender Comparison-30 Minute Length and 20 Minute Length Family Worship Percentage (\%) $\ldots \ldots \ldots \ldots \ldots \ldots \ldots .107$

11. Gender Comparison-10 Minute Length Family Worship Percentage (\%) ............................. 107

12. Members' Participation and Evaluation of the Family Worship

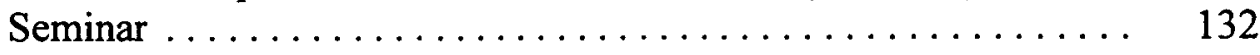

13. Gender Representation in the Evaluation of the Family Worship

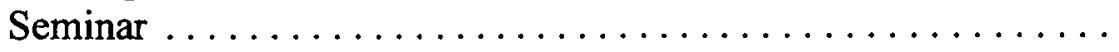

14. Age of the Participants in the Evaluation of the Family Worship

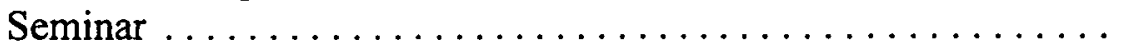


15. Members' Evaluation about the Length of the Family Worship

Seminar

16. General Practicality of the Family Worship Seminar and the Introduction and Practicality of New Ideas to Family Worship

17. Level of Interest of Children in the Family Worship Seminar

18. Level of Parents Who Felt Positively Challenged by the Family

Worship Seminar 


\section{ACKNOWLEDGMENTS}

First and foremost, to God be the glory! The journey has required faith, patience, perseverance, and hard work. I could have not accomplished it without God's comfort and strength. He is always present and has bestowed upon me the blessings of health, determination, and the desire to do something that could be beneficial to His beloved church.

Secondly, I owe my family a lot, especially my wife Angela, for the patience and encouragement given to me during my studies. I deprived my family of my company and many fun times, while I had to lock myself in my office and/or disappear in order to work in seclusion and advance my research and writings. They inspired and motivated me to remain on task, even during my absence from them, which was a big sacrifice for all of us because of my several trips from Australia and Canada to the United States to attend classes and conclude my dissertation. My children Kelly, Kevin, and Kenny had to share 'daddy' with his books, questionnaires, graphics, and the churches, while he was working, studying, and trying to be a father. I must also thank my mother Marly for her continuous prayers for me. God knows that her prayers are sweet and encouraging!

Thirdly, there are some people whom I will treasure in my heart for their attention, support, help, and prayers. Dr. Alfonso Valenzuela has been a very supportive adviser who urged me to keep focused on the topic by providing good ideas and suggestions, as well as his experience in the field of family matters. Mrs. Neroli Douglas 
from Sydney Adventist College in Australia, also sacrificed a good portion of her time editing of my dissertation. She was caring, friendly, and encouraging throughout this venture! Many times she was given limited time in which to review and edit my thoughts in a clearer and more professional way. We worked just fine over the net!

There are two other people whom I am indebted to. Dr. Ricardo Norton was a supporter and an encourager as he made things possible for me to attend the classes and be registered in the D.Min. program even while I was still working in Australia. I do recognize his kindness to me with much appreciation. Dr. Milton Afonso in Brazil was very generous and provided most of the financial resources to assist me in this 'venture of faith.' He has always been someone I could count on and I also owe him much for this accomplishment. Thank you from the bottom of my heart, my dear friend Dr. Afonso!

I am also grateful for the help received by two valuable friends and church members who are also 'computer wizards.' Gleuto Serafim in Sydney, Australia helped me greatly to get acquainted with the formatting of my initial papers and Horatio Stewart in Hamilton, Canada dedicated many hours of his time assisting me with the tabulation of the statistics and graphics of this research. In the same way, I thank Camille Clayton for helping me to finalize the format of the whole dissertation so that it could be according to Andrews University standards.

I cannot forget the support, participation, and words of encouragement from the Hamilton Mountain Church. The members of my congregation were thrilled with the topic and their involvement was vital for the conclusion of this project. I hope and pray that God blesses us all richly as we put into practice the lessons that we all learned during this endeavor. 


\section{CHAPTER I}

\section{INTRODUCTION}

Religious leaders in general perceive family worship as an important element in Christian homes. ${ }^{1}$ Because of its meaning and benefits accruing to Christian homes, family worship is usually referred to as the 'Family Altar.' It can be described as the corporate family spiritual activity that promotes and inspires religiosity and dependence on God among the family members. Youngberg and Youngberg provide an enlightened statement on this topic. They write, "The purpose of the 'family altar' is first and foremost to adore our Lord. It is next to renew the family covenant with God and one another." ${ }^{2}$ Consequently, the conclusion can be drawn that family worship is the specific occasion in which families gather together to honor and praise God as well as to fellowship with one another.

Seventh-day Adventists particularly have been enriched by a considerable amount of literature connecting family worship with the spiritual growth of families. All such books and counsel point out the importance and benefits that are acquired by those who practice family worship in their homes. Such writings provide valuable resources for

${ }^{1}$ Charles Crider and Robert C. Kristler, The Seventh-day Adventist Family: An Empirical Study (Berrien Springs, MI: Andrews University Press, 1979), 65.

${ }^{2}$ John Youngberg and Millie Youngberg, Heart Tuning: A Guide to a Better Family Worship (Hagerstown, MD: Review and Herald, 1985), 26. 
parents and anyone who might be interested in establishing a family worship program in their own home.

In spite of a great wealth of information, there is a decline in the practice of family worship within Seventh-day Adventist families. ${ }^{1}$ Although it would be interesting to discover the reason for such a trend, the main focus of this study is to develop a family worship seminar for the members of the Hamilton Mountain Seventh-day Adventist Church, and to later share it with other churches, too. The aim of the researcher, who is the pastor of the above-mentioned church, is to assist the members of his congregation in conducting practical, relevant, and interesting family worship activities with their respective families.

In order to achieve this goal, some steps need to be taken to lay the foundation of a sound biblical understanding of the meaning of worship. Included is a definition of the term, the origin of worship, and the reason for the ongoing controversy over the topic of worship. This study will also endeavor to give special attention to the meaning of family, which includes a definition of family, its origin and purpose, as well as God's ideal for the human family. Such information will then be linked with the discussion relating to the battle which has been fought over family and family issues, with the foreknowledge that satanic forces are constantly operating to destroy the human family.

For that reason, Jay Adams, writing about the importance of the family by mentioning that it existed long before the church or state, is led to conclude that "the family is foundational ... and that we must make every effort to preserve the family."2

${ }^{1}$ Crider and Kristler, 68.

${ }^{2}$ Jay E. Adams, Christian Living in the Home (Grand Rapids, MI: Baker, 1972), 44. 
Then, it becomes imperative to understand the effect of worship, which began in heaven, and the human family as God's first institution on earth. One of the reasons God created the human family was for the purpose of giving them the privilege of worshipping Him. After the entrance of sin in this world, worshipping God became a means of preserving the human race.

This study plans to introduce the topic of family worship from the perspective of the biblical reasons for its practice within the family circle, which includes the positive influence the church should exercise in promoting Christian values in the home, and that family worship facilitates communication and connection among the members of the family and ultimately with God.

A thorough research will attempt to show that once all of these biblical concepts are clearly understood, it becomes easier to evaluate the importance of family worship for God's children as a way of promoting their closer relationship with God and also with one another.

Despite the fact that the words 'family worship' are not mentioned in the Bible, nor is the modern concept of such practice as it is understood today, the example of some spiritual family gatherings in a number of Old and New Testament households ought to be examined. It will be interesting to note how those spiritual worship activities may possibly depict a form of worship in those family units, which may be compared to those practiced nowadays. These comparisons may reveal significant evidence about how family worship could have played a unique role in the lives of those Bible figures.

This project also proposes to conduct a survey of the available Christian literature dealing with the subject of family worship. The intent is to determine the connection 
between what this literature might have in common, on the topic of family worship, with those Bible examples that will be studied. Also, it will be relevant to consider the content of these writings in order to discover the probable natural development and formation of what is accepted as a family worship activity by contemporary Christian writers. Among these writers, special attention will be devoted to the writings of Ellen G. White, a prominent Adventist leader who has written extensively on this topic.

An extensive investigation of literature could lead to a learning experience about the development, progress, and form that this spiritual family activity took over the years. It will certainly reveal the challenges faced by earlier Christians in relation to family worship. These findings ought to be considered in the light of the problems modern Christians face as they strive to maintain this activity in their homes today.

One of the important sections of this study will be to ponder the role of parents in leading this activity at home with their children. Laurel Burton admonishes parents with remarkable insight: "Children learn about the world from their parents. They adopt many of their beliefs and are introduced to people they know through them." Furthermore, Robert Taylor adds that "a man who takes no interest in teaching his children the will of the Lord is not very interested in going to heaven himself." 2 This offers a clue as to what is expected from the leadership of parents as it relates to their role as the ones who should initiate and lead the family spiritual activities of the home. According to the Youngbergs, another important aspect of this activity, which certainly applies to parents too, is related

\footnotetext{
${ }^{1}$ Laurel Arthur Burton, ed., Religion and the Family: When God Helps (Bingham, NY: Haworth Pastoral Press, 1992), 147.

${ }^{2}$ Robert Taylor, Christ in the Home (Grand Rapids, MI: Baker, 1973), 140.
} 
to the frequency of family worship. "Regularity of this part of the daily routine [family worship] also creates an impression of the importance we attach to it." These points should be further explored and become a pertinent part of the seminar.

A further aspect the researcher aims to introduce is the role and responsibility of the church pastor in promoting family worship among his/her parishioners. This will be presented on a positive note, taking into consideration that the pastor as a spiritual leader should be interested in every aspect of the spiritual growth of his/her congregation.

These biblical, theological, and historical discoveries, as well as the data that the researcher will collect from his church members, through the means of a questionnaire regarding their perceptions and practice of family worship, will provide the necessary background to assist him in devising a family worship seminar that is relevant and practical for his congregation.

\section{Statement of the Problem}

As the pastor of the Hamilton Mountain Seventh-day Adventist Church in Hamilton, Ontario, Canada, the researcher has observed through his preliminary observations and involvement with his church members, during pastoral visits and other interactions with them, that there was a need to enrich the family worship activity in his congregation as a way of enhancing their spiritual growth and relationship with God. $\mathrm{He}$ is also aware of the fact that since sin entered this world, satanic forces are striving to block and destroy the relationship between God's children and their Creator. As a result,

\footnotetext{
${ }^{1}$ Youngberg and Youngberg, 90.
} 
it has brought serious consequences to Christian homes, ultimately tearing many families apart.

It is the firm belief of the researcher that the regular practice of creative, interesting, relevant, and practical family worship activities in Christian homes could assist families to enhance their spiritual experience with God and provide them with the necessary spiritual strength to face the opposition forces that conspire against their stability and happiness. He believes that the church should be the leading human agency in providing the opportunities for spiritual growth, as well as showing interest in addressing the spiritual needs of its members. Therefore, creative plans and ideas ought to be designed to assist Christian families to remain together in this sinful world and, through the grace of God, win the battle against the one who is pressing for their destruction.

\section{Purpose of this Project}

This project proposes to develop, describe, implement, and evaluate a creative, attractive, relevant, and practical family worship seminar for the members of the Hamilton Mountain Seventh-day Adventist Church as a means of assisting them to develop a daily, closer, intimate, and corporate relationship with God, as well with family members.

\section{Theoretical Rationale}

In the modern and fast-paced society of today, even Christians feel pressed to live a kind of religion that does not involve much more than attending the weekend service at church. This situation tends to suppress the time, creativity, and dedication to religious 
matters so long cherished and exemplified by early Christians. In most of the countries of our so called 'civilized world,' especially in the Western nations, to be a Christian does not involve running the risk of suffering persecution or being marginalized. It is sad to notice the reality that in some of these places Christianity has become lax and superficial.

Numerous Christian publishing companies have produced abundant Christian literature which is mainly focused on issues related to corporate religious activities, including the church service, or promoting a motivational personal relationship with God. This comes across through rich and inspiring material which presents valuable suggestions to enhance ministries in various departments of the church. They especially show how to enrich the church service and make it attractive and meaningful to members. Other writings reveal how to have a private and fulfilling relationship with God through prayer, the essential study of Scripture, and involvement in service to our fellow human beings, among other relevant things. This is indeed commendable and satisfying!

However, the unfortunate fact is that there is a gap between the personal, individual relationship with God and the one that takes place in the church. This space should be filled by an appropriate and fitting family worship activity or program. Most of the present Christian literature does not address this issue in practical ways, nor is it mentioned in personal devotional or corporate church disciplines.

There is an urgent need to change this pattern. Family worship ought to be promoted among Christian families and more practical materials need to be designed and made available to them. The elements of Christian corporate worship and the joys associated with that need to be first practiced at home. This will assist in the 
development of a God-fearing character in each family member, especially the impressionable children. Family worship at home will prepare the family for worship at church, where their cherished moral Christian values and blessings will reflect the intimate relationship, love, and respect within the family circle, as they associate with their fellow believers at church.

Families need to be inspired and motivated by family worship and the redemptive and fulfilling aspects of it, so that it becomes entrenched as part of their lifestyle. This will assist to bridge the gap between personal, private spiritual growth and the corporate worship of the church where faith and love for God are expressed. That is why personal devotion to God is crucial-it is the first step in a person's daily experience with God. In contrast, when the practice of personal devotion is non-existent, family worship does not happen either. ${ }^{1}$ Therefore, the natural and progressive spiritual growth of a Christian in his or her relationship with God should include a personal devotion plan, a family worship activity (for those who have family members with them, even if it is just the husband and wife), and participation in the church worship service. This three pronged 'system' of worship will provide a safeguard against the forces of evil and most of all, the joy and pleasure of wholehearted worship of the Creator God.

That is why this study involves addressing the issue of making family worship a joyful, creative, and practical experience in the lives of the members of the Hamilton Mountain Church.

${ }^{\mathrm{I} Y o u n g b e r g}$ and Youngberg, 62. 


\section{Importance of the Study}

After placing considerable value and emphasis on the importance of a regular and practical family worship activity, it is anticipated that this project of incorporating a family worship seminar will bring some specific benefits to the church members.

First of all, the expectation of the researcher is that this study, and especially the proposed seminar, will bring a better understanding of the topic to the members of his congregation. Second, he believes that the family worship seminar itself should help to address the need for more practical literature and studies about family worship. Third, this study will include the design and implementation of an instrument in the form of a questionnaire to measure the understanding and actual involvement of the congregation in family worship. Fourth, the seminar will be made available to other pastors with the purpose of assisting them in promoting this topic in their respective congregations.

He also anticipates that the seminar will produce a three-fold result among the members of his church. It should create a positive awareness about the topic in the church and introduce new ideas and methods which will serve to encourage the ones who are presently practicing this spiritual activity, providing them with fresh insights so they can make it even better. As well, it should instill a desire in the hearts of those who have not been engaged with family worship to adopt it and practice it with their families.

\section{Definition of Terms}

The following definitions of terms are presented, as used during the stages of this project:

Family Worship. During the whole process of this study, which includes the biblical and historical research on the topic of family worship, as well as the designing of 
a family worship seminar, this activity is defined as the spiritual gathering of family members in their own home environment in order to conduct a spiritual and religious activity among themselves. Especially for the members of the Seventh-day Adventist Church, this spiritual gathering typically includes the singing of religious songs, reading of the Bible or other devotional book, reciting of Bible verses or promises, the study of the Sabbath School lesson, and prayers.

Family Worship Questionnaire. The Family Worship Questionnaire is an instrument that was designed with the intention of collecting information about the perceptions, understanding, and practice of family worship among the members of the Hamilton Mountain Seventh-day Adventist Church.

Final Evaluation Survey. The Final Evaluation Survey is an instrument that was devised with the purpose of measuring the final perceptions, interest, and evaluation of the participants of the family worship seminar in regards to its content and presentation.

Hamilton Mountain Seventh-day Adventist Church. A multi-ethnic cultural Seventh-day Adventist Church located in the city of Hamilton, in the province of Ontario, Canada, comprised of members originating from various parts of the world.

Ontario Conference of Seventh-day Adventists. A regional legal religious organization that is responsible for the preaching of the gospel according to the beliefs of the Seventh-day Adventist Church and for administering the interests, funds, and placement of workers in the Seventh-day Adventist churches in the Province of Ontario.

Seventh-day Adventists. A worldwide religious organization of Christian believers who accept Jesus Christ as their personal Savior and believe in the literal return of Jesus at the end of this world to cease the human predicament of suffering that was 
caused by sin. Seventh-day Adventists distinguish themselves from mainstream Protestant beliefs by their acceptance of the seventh-day Sabbath as the sacred day of worship, the intercessory ministry of Christ in the heavenly sanctuary on behalf of the repentant sinners, and that eternal rewards come at the end of the world during the second coming of Jesus, rather than at the time of death of the human person.

\section{Assumption of the Study}

The major assumption of this project was that despite of many factors that conspire against the practice of family worship in the homes of the members of the Hamilton Mountain Church (e.g., time, lack of information, interest, materials, among others), they still value this Christian exercise and tradition and are willing to show interest in learning about the spiritual blessings associated with its practice. It was also assumed that a representative number of the persons responding to the family worship questionnaire would not be involved with the subject or practice family worship.

This study based its presumptions on the list of variables of aims, methods, and attitudes, related to the practice of family worship, that are mentioned in the questionnaire as elements and reactions to the family worship activity that happens in the home settings of the members. The analysis of the results of that instrument assisted the researcher in the preparation of the family worship seminar.

\section{Delimitations and Limitations of the Study}

This study and its final project, the family worship seminar, were delimited to the members of the Hamilton Mountain Seventh-day Adventist Church in the Ontario Conference. The final results cannot be generalized to any other group of believers or 
population. This study was also limited to the perceptions and performance of the members regarding their own family worship practice and experience.

During this study and project, every effort was made to offer the members who were targeted to participate in different stages of the process, either through the family worship questionnaire, family worship seminar, and final evaluation survey, both positive and negative information related to the practice of family worship. No attempt was made to exercise any control of the members' negative responses in the final result of this project.

The study did not endeavor to evaluate the definite spiritual impact caused by the practice of family worship in the homes of the members, although the questionnaire contained some questions related to the parents' perceptions of their children's attitudes, as a probable positive result of the spiritual influence exercised through the practice of family worship in their home setting.

It was not the intention of this study and project to measure the members' actual implementation of the family worship program which was suggested to them during the family worship seminar, although they were strongly encouraged to do so.

The literature reviewed was comprehensive but not an exhaustive investigation on the topic of family worship. It served the purpose of providing a biblical, theological, and historical backdrop for the limitation of this study and also to present the evidences of this Christian experience and tradition as a motivational factor for the selected population in this study.

The particular Seventh-day Adventist Church literature on the topic, mainly in the form of the writings of Ellen G. White, was presented with the intention of revealing the 
importance given to the subject in the religious context and expectations associated with this practice in the homes of believers. It was not the object of this study to explore the reasons and/or implications associated with the thoughts and mindset of the writers.

\section{General Overview of the Dissertation}

Chapter 2 presents a review of the biblical, theological, and historical literature related to the topic of family worship. This chapter also includes the development of the practice of family worship from biblical times, with Old and New Testament examples, until the recent Protestant approaches to the topic, with special emphasis on the view and expectations associated with the topic by Seventh-day Adventists.

Chapter 3 deals wholly with the demographics of the city of Hamilton, Ontario, Canada; a brief history of the Hamilton Mountain Seventh-day Adventist Church; the population and sample of this project; the development of the instruments, the Family Worship Questionnaire and the Final Evaluation Survey; as well as the rationale associated with these instruments. This chapter also introduces the explanation of the methodology utilized for the development and presentation of the family worship seminar and the analysis of the data collected from the church members through the instruments used in this project. The findings of the questionnaire assisted the researcher in the preparation of the family worship seminar, while the final evaluation survey helped him to make the conclusions and final recommendations associated with the family worship seminar.

Chapter 4 is devoted to reporting the procedures and findings of the family worship questionnaire, including tables and charts of the discoveries of the instrument used with the members of the Hamilton Mountain Church. It also includes the analysis 
and interpretation of the data collected as they relate to the perceptions, practices, and experience of the church members with the topic of family worship.

Chapter 5 introduces a theoretical, structured, and short version of the different phases of the seminar as they related to its development, description, implementation, and evaluation. The seminar itself, word by word is presented in the appendix of this project. Chapter 6 delivers the summary of the research and project and also the results of the final evaluation survey completed by the participants of the family worship seminar after its presentation. These data assisted in the draft of the conclusions and final recommendations and suggestions related to the seminar. 


\section{CHAPTER II \\ FOUNDATIONS ON FAMILY WORSHIP}

\section{Introduction}

In order to establish the foundations for family worship it is crucial to understand the meaning of worship. Anna Laura and Edward Gebhard claim that "the root of the word "worship" is "weorth-scipe"-worth-shape. Worshipping means literally shaping our worth or values." Richard Lentz adds that the act of worship "is perhaps the most profound and personal experience of the human soul.,"2 The sinful condition of our world has created a situation in which there is an ongoing controversy about worship, where two contenders are striving for the right to be worshipped. This is the focus of the discussion which follows.

The Controversy about Worship

Worship began in heaven. God the Creator and the supreme sovereign of the universe has been worshipped by heavenly beings since eternity. ${ }^{3}$ The angelic host could show their reverence and love to God in face-to-face relationship with Him. The

'Anna Laura and Edward Gebhard, Our Family Worships at Home (Nashville, TN: Abingdon, 1958), 11. 5.

${ }^{2}$ Richard E. Lentz, Christian Worship by Families (St. Louis, MO: Bethany Press, 1957),

${ }^{3}$ Ellen G. White, Patriarchs and Prophets (Mountain View, CA: Pacific Press, 1958), 37. 
heavenly beings took pleasure in paying homage to their Creator as they all lived in harmony and reflected His glory. ${ }^{1}$ The contemplation of His glory brought them a sense of awe ${ }^{2}$ and the worship of God set the tone for a perfect and joyful atmosphere. They were able to revere God in a setting which contributed to their perfection, holiness, and gratitude (Ps 96:6; Rev 5:11-12). ${ }^{3}$ Hence, surrendering to God was then, as it is today, the heart of worship ${ }^{4}$ since it reveals the love response of His creatures for their Creator.

Thus it is not difficult to envision worship as an activity which was conceived sometime in eternity with the divine purpose of adoration of God the Creator and keeping His creatures holy. Worship was designed in a perfect and safe place-heaven. The created beings were pure and holy with no trace of any malice. Worshipping God would protect their characters from such a possibility. In such conditions, sin was an unknown element and as long as the heavenly host worshipped God it would remain that way.

Worship was also God's first gift to the newly created human couple. He set aside a day of rest, a Sabbath day, to provide a special occasion on which they could adore Him as their Creator and remember their origin (Gen 2:1-3). Through Adam and Eve this day was to be one of rest and worship for all humanity. ${ }^{5}$ Thus, family and

${ }^{1}$ Ibid., 35. 1989), 169.

${ }^{2}$ Dennis Guernsey, Sometimes It's Hard to Love God (Downers Grove, IL: InterVarsity,

${ }^{3}$ Unless otherwise indicated all Bible references in this paper are from the New International Version.

${ }^{4}$ Rick Warren, The Purpose Driven Life (Grand Rapids, MI: Zondervan, 2002), 77.

${ }^{5}$ White, 48. 
Sabbath were created at the end of creation week for the benefit of the human race.

Today, these two institutions retain their original purpose and are signs of God's power.

Then, sometime in past eternity, sin entered the universe because some of the angelic host, led by Lucifer, did not want to recognize God as the sovereign ruler of the universe anymore. Lucifer challenged God concerning His right to be worshipped and desired to take His place, proclaiming himself as the new entity to be worshipped and praised (Isa 14:12-14). The holy atmosphere of heaven was changed into a battlefield and the enemies of peace were thrown out of heaven (Rev 12:7-9). From heaven, the enemy transferred his evil intentions to the newly created earth as he induced the first human beings to sin against God by not obeying His commands (Gen 3). Worship was at the crux of events which caused sin to come into existence, bringing with it terrible consequences (Rom 5:12;6:23). Both in heaven and on earth, rebellion revolved around not worshipping God correctly. On one side God is perceived as claiming His right to be worshipped. On the other, Satan cunningly strives to deceive humanity into offering God an improper worship, one that in reality is worship of self. ${ }^{1}$

Throughout the Bible this battle over worship is reiterated. This is evidenced in the Old Testament by the Israelite nation and their stories of uninterrupted tension between the true worship of God and the people's constant falling to the seductions of idolatry. ${ }^{2}$ In the New Testament, the last crisis of human existence is one of worship $(\operatorname{Rev} 13: 4,8,12,15 ; 14: 7)$.

${ }^{1}$ Ibid., 71-72.

${ }^{2}$ J. A. Motyer, "Idolatry," New Bible Dictionary, ed. James D. Douglas (Wheaton, IL: Tyndale, 1992), 503-505. 


\section{Defining Worship}

According to Bernard Schalm, worship "is man's joyful response to God's revelation." Thus, worship involves two main elements: God's self-initiated disclosure and human response to that revelation. The Bible shows that God's children offer worship only in response to divine self-revelation (1 John 4:8, 19). God, by His nature, defines worship as a response to the revelation of Himself (Exod 20:1-7). Worship is the only way humanity can know God, the transcendent being above and outside nature. God is the first reality in worship. Worship has no meaning if it does not acknowledge God's sovereignty and that He has revealed Himself. ${ }^{2}$

Worship is objective because it does not originate in inward experience and it responds to "reality and phenomena independent of man."3 God is the One who initiates the action and worship is the human response to God's revelation of Himself and man's desire to know the Creator. It cannot be conceived as the fulfillment of a human wish. It is because God reveals Himself that humans can draw closer to Him through the act of worship, since God designed humanity to worship Him. ${ }^{4}$ This revelation of God highlights His interest in a relationship with His worshippers, resulting in their understanding of God. Worshipping God is thus a sanctifying act (Ps 95:6-7; John 4:2224).

${ }^{1}$ Bernard Schalm, The Church at Worship (Grand Rapids, MI: Baker, 1962), 11.

${ }^{2}$ Ellen G. White, Great Controversy (Mountain View, CA: Pacific Press, 1950), 436-438.

${ }^{3}$ Paul Waitman Hoon, The Integrity of Worship: Ecumenical and Pastoral Studies in Liturgical Theology (New York, NY: Abingdon Press, 1971), 52-53.

${ }^{4}$ Warren, 82. 
Jack Hayford states that worship recovers all that Adam lost, being God's way for all humanity to restore dominion in their lives. ${ }^{1}$ The worship of God being an antidote to sin offers fallen and unworthy humans the opportunity to come before God "in the full expectation that His holy wholeness will answer our unwhole unholiness." ${ }^{2}$ Through worship, unmerited humanity is covered by God's available transforming power for those who come into His presence with humility and recognition of His love.

For Florence Lee, worship is the "feeling inside you that you belong to God and it is showing God you love Him and are glad He is your God."3 A sense of awe is felt when one comes into God's presence. Worship can be an individual or corporate experience with God but in any case, it should be "the most important, creative, and stabilizing experience of life." Robert Webber defines worship as "a means through which we can see, hear, smell, taste, feel, and come into contact with the infinite." 5

\section{Worship Is a Celebration}

Worship celebrates something special, as portrayed in the happenings of the Old and New Testaments. It is also a celebration of what God does for His children. ${ }^{6}$ In the Bible, worship is bound by acts performed by God for the benefit of His creatures.

'Jack W. Hayford, Worship His Majesty (Dallas, TX: Word Publishing, 1987), 38.

${ }^{2}$ Ibid., 177.

${ }^{3}$ Florence B. Lee, et al., When Children Worship (Chicago, IL: Judson Press, 1963), 5.

${ }^{4}$ Ibid., 11 .

${ }^{5}$ Robert E. Webber, Worship Is a Verb (Waco, TX: Word Books, 1985), 195.

${ }^{6}$ John C. A. Barnett, Family Worship (London: Epworth Press, 1982), 42. 
In the Old Testament the heavenly host revered God for being their Creator and sovereign God. ${ }^{1}$ Worship for the first human couple was also linked with their creation, as they worshipped God for being their Creator. ${ }^{2}$ The Israelites worshipped God for delivering them from their bondage in Egypt (Exod 14:31).

The New Testament presents Jesus as God's personal revelation and the worship of Him is instituted by His redemptive death on the cross of Calvary. Worship of Christ is a celebration of what He achieved for the salvation of humanity. Human worship is a response to these divine acts ${ }^{3}$ and a celebration of God's mighty deeds. Webber adds, "Biblical worship celebrates the event and makes it come alive again."

\section{Reason for Worship}

Once the meaning of worship is understood, it becomes easier to develop a comprehensive answer regarding the reason for worship. Because of the sin problem the battle for worship is one that will continue until the end of human history. The two parties involved in this conflict are targeting humanity for different reasons and objectives. The contenders in this strife are God and Satan. God exercises His rightful desire to continue to be worshipped, as $\mathrm{He}$ is the Creator and overseer of His creation. Satan, as a rebellious creature, wants to supplant this privilege which belongs to God alone. Satan proclaimed himself as the new ruler of this world after sin became a reality (Luke 4:6). The real question regarding worship is a matter of loyalty to one or the other.

\footnotetext{
${ }^{1}$ White, Patriarchs and Prophets, 36.

${ }^{2}$ Warren, 85 .

${ }^{3}$ Barnett, 38.

${ }^{4}$ Webber, 34 .
} 
For God it is a condition of preservation of His character before His creation, while for Satan it is a struggle to satisfy his ambition for power and self-adoration. ${ }^{1}$

God's creatures need a rational, sanctified will in order to truly worship Him (Rom 12:1-2), while those who follow Satan's way are dominated by a defiant attitude against God. Sanctified reason calls for worship of God but the sinful nature ventures to deny God's rights. Worshipping God results in eternal life (John 17:3), while those who follow Satan's path of sin will receive the death sentence (Rom 6:23). The attitude of those who worship God is one of devoted and joyful submission. By contrast, those who are followers of Satan exhibit unfaithfulness and rebellion. The heart of the matter concerning worship is for the Christian to attain to God's character as revealed in His law and to rely on His power to uphold it. ${ }^{2}$ Those who defy the true worship of God want to experience freedom from His law, which is ultimately a challenge to His sovereignty. ${ }^{3}$

\section{The Family and Worship}

God is the Creator of the family. Through holy union the family was the first institution created and blessed by God (Gen 1:27-28). God solemnized matrimony between the first human couple. Humanity was created when Adam was made according to God's image (Gen 1:27). It was God's plan that the new human couple should worship Him as their Creator ${ }^{4}$ and grow in number. Ever since, the family has been the

${ }^{1}$ White, Great Controversy, 494.

${ }^{2}$ Ibid., 493.

${ }^{3}$ Ellen G. White, Desire of Ages (Mountain View, CA: Pacific Press, 1940), 762-763.

${ }^{4}$ White, Patriarchs and Prophets, 47-48. 
smallest but the most important unit of society on earth. LaHaye claims that "there is no substitute for the family! It will never be replaced."

The Goal of the Christian Family

It is commonly accepted that family is an essential ingredient for the satisfaction and fulfillment of humans, bringing a sense of belonging and acceptance that is necessary for the well-being of a person. Family should be a place where people are welcome because of their relationship rather than performance and accepted and received with warmth, despite their faults and failures. ${ }^{2}$

According to Anderson, the family is a unit that provides a stable social order influencing society in such a way that its strength results in the strengthening of society. ${ }^{3}$ It is "the most potent moral, intellectual and political cell" and its "well-being is regarded as critical for society's survival." Family also has a spiritual relevance because it is "the unit for Christian nurture ${ }^{, 5}$ whose influences impact generations. The case of Abraham is a typical biblical example. Because of his loyalty and love for God, through him and his family the whole human family was blessed (Gen 12:3).

The family should function as a spiritual, social, emotional, and moral institution that assists the development of human beings in reaching their full potential. It is a

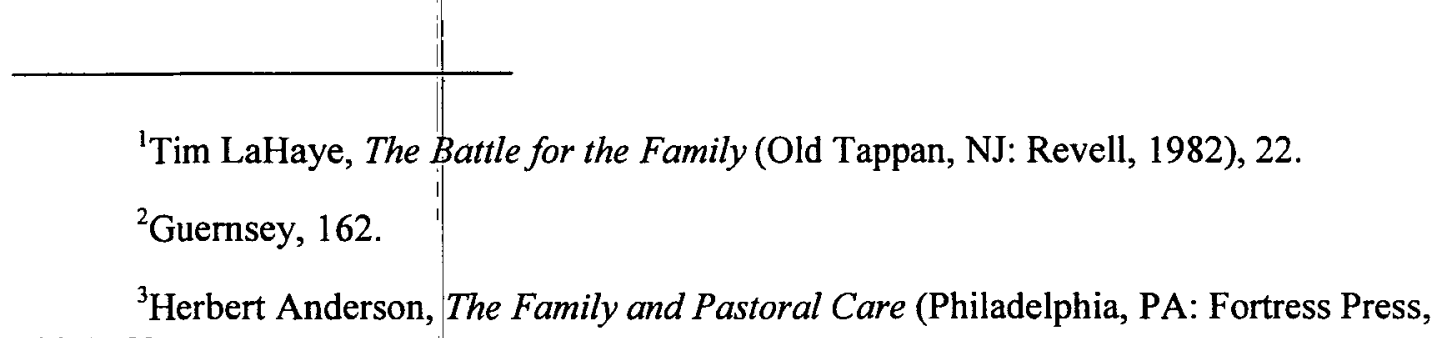
1984), 59.

${ }^{4}$ Ibid.

${ }^{5}$ Ralph Heynen, The Secret of Christian Living (Grand Rapids, MI: Baker, 1966), 26. 
catalyst that by its created purpose helps to ease the human predicament of suffering as a result of sin. The ultimate goal of the family is to return to God's original divine plan in Eden when He married the first couple, establishing an institution that promotes emotional and physical stability, as well as spiritual growth in its members. ${ }^{1}$

Ralph Heynen adds that the family "is still the most important unit in society, in the church, and in the line of God's way of working." Such a statement enhances the idea that family is the prime institution by which God wishes to accomplish His plans for the restoration of humanity. This message must be sent to the homes of God's people as they prepare their children to be influential in this world. The example of such homes causes an impact in the world that goes beyond human understanding. "The goal of Christian family life is not solely to create a family which functions in a healthy manner but also to help the world become a better place for the spirit of God to dwell.",

God's ideal for family goes back to creation. He designed His human creatures to come into existence through a family. God formed the first human family in Adam and Eve and $\mathrm{He}$ gave them the capability to increase in number and to be in charge of His creation (Gen 1:27-28). The theology of the family involves two purposes. The first is that it is a necessary component of creation as it guarantees the continuity of the human 1

${ }^{1}$ Ellen G. White, Adventist Home (Washington, DC: Review and Herald, 1952), 26-28.

${ }^{2}$ Heynen, 23.

${ }^{3}$ Ellen G. White, Child Guidance (Hagerstown, MD Review and Herald, 1997), 163.

${ }^{4}$ Joe Leonard, Family Ministry (London: Scripture Union, 1988), 9. 
species. The second, as taught by Christ, is that family cannot be an end in itself, as it needs to enlarge its boundaries for others to come and join as the family of God. ${ }^{1}$

Today, humanity remains as a witness of God's creative power. Humanity is the crowning work of God's creation ${ }^{2}$ and a kind of a revelation of God Himself through His creation. God designed family to be a place of love, affection, courtesy, and happiness. ${ }^{3}$

After sin was introduced, God's plan for the redemption of humanity included His faithful children and their families being given the opportunity to reach others by their witnessing to His salvation. "In both the Old and New Testaments, God's purpose in revealing Himself, in redeeming, and in bringing a people into existence was to create a worshipping community to be a sign of His redemptive work."

In the Bible the concept of serving God is to worship Him (Deut 10:12-13; Josh 24:15; 1 Sam 7:3; Rom 12:1; Heb 9:14; Rev 5:10). Warren says that the first responsibility of humans is to worship God. ${ }^{5}$ To worship God is to joyfully surrender to His authority, mercy, and love. ${ }^{6}$ Serving God passionately then becomes an act of worship, which will result in one's unselfish service to others, too. ${ }^{7}$

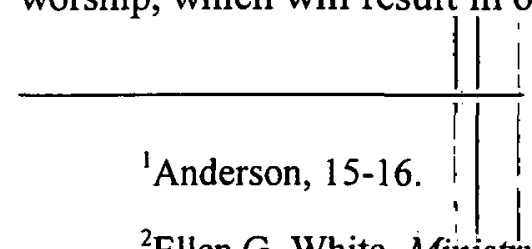

${ }^{2}$ Ellen G. White, Ministry of Healing (Mountain View, CA: Pacific Press, 1942), 415.

${ }^{3}$ Ellen G. White, Testimonies for the Church, 9 vols. (Mountain View, CA: Pacific Press, 1948), 4:621-622.

${ }^{4}$ Webber, 36 .

${ }^{5}$ Warren, 55.

${ }^{6}$ Ibid., 77.

${ }^{7}$ Ibid., 234-239. 


\section{The Battle over the Family}

The human family ${ }_{\mid}$was the first place in which Satan concentrated his efforts to bring destruction and grief, after he was expelled from heaven. He tempted Adam and Eve, leading them into sin against God. Since that time, the human family has never experienced a peace treaty with him. Not fully satisfied with this temporal triumph, Satan caused Cain to kill his brother Abel as the result of a worship contest (Gen 4:8), winning another battle in the war regarding worship that he had launched against God.

Satan knows the importance of the family as designed by God. In this Godordained unit he focuses his attacks in two fronts to distort the image and knowledge of God. ${ }^{1}$ First, he tries to destroy the family ties of relationship, trust, and dependence upon God. Such relationship could well be called communion. Second, he dedicates his time to turning the family against God. If he succeeds in his first objective, the second will be achieved because where God is not trusted and loved; He will be treated with indifference leading to rejection. ${ }^{2}$ Satan is aware of this reality and he knows "that the family is the world's most powerful agency." ${ }^{3}$ He wants to destroy the family to hurt God's children, bringing them sorrow and despair which will also defy and hurt God Himself. Thus, God will be portrayed as incapable of easing the suffering of humanity, thus leading His children to doubt His love for them (1 Kgs 19:4; Job 2:9; 6:4; Matt 11:1-3).

This is the reason Satan implements his demonic plan aimed at diminishing the importance of the worship relationship between the human family and God. In his war

\footnotetext{
${ }^{1}$ White, Desire of Ages, 24.

${ }^{2}$ White, Testimonies, 5:738.

${ }^{3}$ Heynen, 19.
} 
over worship, Satan is in constant work in the family ${ }^{1}$ trying to put himself in an advantageous position by weakening the family's interest in communion with God.

\section{Reason for Family Worship}

Family worship is ivital and should be given priority over other activities at home. ${ }^{2}$ The battle is fiercely fought in the family home, the very root of family existence. The contenders are investing their best efforts in this battle. God wishes to maintain and encourage a relationship with Him by recalling His plans for the family and the positive influence of a happy family in human society at large. ${ }^{3}$ Contesting God, Satan strives to destroy the family through intrigues, licentiousness, and by lowering its spiritual standards ${ }^{4}$ leading people to depart from God's original plan for the family. Ellen White states that Satan utilizes his best tactics to war against and destroy the purposes of God ${ }^{5}$ and especially to discourage the family relationship with God. ${ }^{6}$

Christian homes should be the ideal places in which worship is to be practiced as a meaningful experience with God and a celebration of His actions. The Old Testament portrays the example of Abraham who worshipped God with his household wherever he pitched his tent. ${ }^{7}$ In the New Testament most of the Christian churches were home

${ }^{1}$ White, Great Controversy, 585.

${ }^{2}$ Alfonso Valenzuela, Como Fortalecer La Familia (Pasadena, CA: Living Ministry, 205), 192.

${ }^{3}$ Ellen G. White, Christian Service (Washington, DC: Review and Herald, 1983), 208.

${ }^{4}$ White, Adventist Home, 326-327.

${ }^{5}$ White, Testimonies, 3:469.

${ }^{6}$ White, Testimonies, 5:738.

${ }^{7}$ White, Testimonies, 7:44. 
churches. ${ }^{1}$ The conclusion may be drawn that the homes of those who served the Lord were always associated with places of worship. The believers' homes are still the place where they can worship God and from there, God wants them to influence the world. ${ }^{2}$

The family was created by God to be "the world's most powerful agency." Unfortunately, the lowering of principles and values that concern the family has weakened the family institution and left consequences which threaten its existence. Every year an extensive number of 'orphan' children with live parents are thrown to the mercy of society, and the world's courts eventually determine the destiny of innocent children because of dysfunctional families. ${ }^{4}$ Such tragic events have a long and destructive effect on society in general, but even worse is the fact they are becoming common occurrences within the church. ${ }^{5}$ The church was established to be God's appointed agency for the salvation of all, ${ }^{6}$ and this includes the uplifting of family values. Yet, it is suffering from this common corrupt influence in society. The question then is how can the church possibly employ its positive influence in impacting the world?

Christian homes should be safe and happy places. ${ }^{7}$ All expressions of affection and activities should make it a proper place where characters are developed and members prepared to serve God and society. The home is the first school for the children and it is

${ }^{1}$ C. F. D. Moule, Worship in the New Testament (Richmond, VA: Johnn Knox, 1961), 266.

${ }^{2}$ White, Adventist Home, 318.

${ }^{3}$ LaHaye, 22.

${ }^{4}$ Leonard, 38-40.

${ }^{5}$ Ibid., 38.

${ }^{6}$ Ellen G. White, Acts of the Apostles (Mountain View, CA: Pacific Press, 1997), 600.

${ }^{7}$ White, Ministry of Healing, 394. 
the place where the first instructions for life are received. ${ }^{1}$ A special responsibility is laid upon parents to accompliṣh this ideal. ${ }^{2}$ They are God's human agents to raise a strong and noble family to be of service to God and society.

The Bible and Christian literature reveal the importance of family worship and why it should comprise part of the daily schedule of Christian families. ${ }^{3}$ It can be a blessing and a safeguard against the enemy. Thus, it is vital to expand on the purposes of worship and consider the family home as the primary venue for this activity.

\section{Purposes of Family Worship}

The first purpose of family worship is to worship God. ${ }^{4}$ The time spent together for this purpose is to be perceived as a rewarding investment for the family. Worship has been defined as "the wonder of the creature as he senses the presence of His Creator." When the family gathers together to worship God, it experiences the awe of His presence and the power of His love. There the family members can enjoy a private and personal communion with their God. These daily meetings with God develop strong, affectionate, and spiritual bonds in the family and with God, both as individuals and on a corporate basis. In the quietness of the home environment, His Spirit speaks softly to each person and brings His blessing.' 'If the Holy Spirit is pre-eminent in the home, He will give

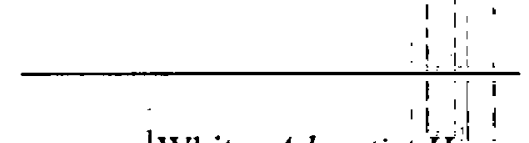

'White, Adventist Home, 181.

${ }^{2}$ Ibid., 44 .

${ }^{3}$ White, Child Guidance, 520.

${ }^{4}$ Mae C. Bradley, "The Happiest Hour of the Day," Review and Herald, December 13, 1945, 15.

${ }^{5}$ Youngberg and Youngberg, 28. 
overcoming grace to the members of the family in all the difficulties, sorrows, and struggles of life."1 God's Spirit works with grace and love at home.

Burton accepts that "religion is an important mechanism for providing the family with a means whereby it integrates its identity as a family unit ... preserving itself as a unit over time." ${ }^{2}$ Religion is a source of family strength. Its practice helps the family to maintain itself as a unit. Hence, religious families find themselves with a distinct advantage over those who do not follow religious practices.

Religious leaders agree that family worship forms an integral part of the Christian lifestyle. ${ }^{3}$ Family worship is an important activity in making the religious life of the family more practical and alive. It is the field of applied religion for the family because by its own nature it promotes a relationship with God and a stronger bond between the members. Ellen White compares the home where God is not worshipped to a ship without a pilot. ${ }^{4}$ Because family is so important to God, He has a great deal of interest in seeing this institution well preserved. He desires that family members live in peace and harmony. ${ }^{5}$ God wants His children to experience a heavenly atmosphere in their homes on earth because, "since the Garden of Eden the family has been the most important 120.

${ }^{1}$ Norman V. Williams, How to Have a Family Altar (Chicago, IL: Moody Press, 1951),

${ }^{2}$ Burton, 179.

${ }^{3}$ Crider and Kristler, 65.

${ }^{4}$ White, Adventist Home, 350.

${ }^{5}$ White, Testimonies, 5:547-548. 
educational agency on Earth." There, its members can practice the basic elements of the Christian life, sharing the blessing of a closer relationship with God and each other.

\section{Family Worship in the Old Testament}

In biblical times, patriarchs did not have a church in which to worship God. God was primarily worshipped at home. The words 'family worship' are not mentioned in the Old Testament, but there are indicators about the concept of family worship as it is understood today exemplified in the lives and homes of preeminent biblical figures. The Bible reveals expressions and symbols that have been assimilated in the practice of family worship.

In the Old Testament there are two distinct situations: First, Adam and Eve enjoyed a perfect relationship with God including the privilege of worshipping Him face to face ${ }^{2}$ before they sinned. 'Although the Bible does not specifically mention the first couple's worship of God, it is clearly implied that they took pleasure in this type of relationship with their Heavenly Father. The second situation involves the remainder of the Old Testament where sin was already a reality for the descendants of Adam and Eve.

The first time in the Bible that human beings are involved in a specific form of worship occurs in the story of Cain and Abel (Gen 4). Although it is difficult to establish

${ }^{1}$ Kenneth O. Gangel and Warren S. Benson, Christian Education: Its History and Philosophy (Chicago, IL: Moody Press, 1983), 21.

${ }^{2}$ White, Patriarchs and Prophets, 50. 
whether they were participating in a structured form of worship with their parents, the fact that they brought an offering to God reveals the practice of worship. ${ }^{1}$ Although sin already existed, they were still willing to present an offering as an act of worship to God. The story of Noah brings much light to the subject of family worship. The Bible mentions that after the flood, Noah and his family built an altar and they all worshipped God (Gen 8:18-20). In turn, the Lord promised the earth would never be destroyed again by water (Gen 9:11). He blessed Noah and his family, giving them the same authority over the animals He had given to Adam and Eve, including the capacity to reproduce and fill the earth again. God also blessed the earth itself because of Noah's faithfulness (Gen $8: 18-9: 2$ ). The building of the altar by Noah is relevant for the fact that it certainly expressed his gratitude to God and his faith in Him. ${ }^{2}$

Abraham's story shows how this patriarch lived a life of faith and dependence upon God (Heb 11:8-12) Abraham always built altars to worship God with his entire household wherever he pitched his tent, ${ }^{3}$ not only with his immediate family members but also with all of those who were with him on his journeys. This is a clear statement that expresses Abraham's faith and his desire to reach others as he worshipped God.

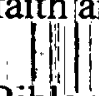

In Gen 46 the Bible mentions the story of Jacob on his way to Egypt to meet his son Joseph. After many years of grieving because he believed his son Joseph was dead, the news about his son being alive and ruling over the land of Egypt brought peace to Jacob and revived his spirit (Gen 45.27). He then left to travel to Egypt with all that Jacob and revived his spirit (Gen 45:27). He then left to travel to Egypt with all that

${ }^{2}$ White, Patriarchs and Prophets, 106.

${ }^{3}$ Ibid., 128. 
belonged to him. When "he reached Beersheba he offered sacrifices to the God of his father Isaac" (Gen 46:1). Beersheba was the place where Abraham (Gen 21:33) and Isaac (Gen 26:25) had erected altars to God. There Jacob also offered sacrifices to God and he "commended himself and his family to the care of God."

The habit of the patriarchs in building altars is an important element of the Old Testament concept of family worship. ${ }^{2}$ Considering that Jacob was accompanied by his entire household on his journey to Egypt, it implies that the whole family gathered around the altar to worship as Jacob offered sacrifices to God.

The family bond was very strong in Jewish culture and "the center of religious life has always been the home" ${ }^{9 !}$ although this concept of close connection in the family was compromised during slavery, in Egypt. The Jewish families always referred to their homes as their sanctuaries, ${ }^{4}$ as a place that had been set aside for special purposes like the worship of God, the learning of the Torah, and a place to serve community needs. The principle was that each home should reflect God's glory through prayer and praise. It should be a place where the father acted like a priest for his entire household as he ministered for his family. ${ }^{5}$ This describes the concept of family and the goals for the

l"Came to Beer-sheba," SDA Bible Commentary, ed. Francis D. Nichol (Washington, DC: Review and Herald, 1953-57), 1:466.

${ }^{2}$ Youngberg and Youngberg, 22-23.

${ }^{3}$ Marvin R. Wilson, Our Father Abraham (Grand Rapids, MI: Eerdmans, 1994), 216.

${ }^{4}$ Joseph H. Hertz, 'ed., A Book of Jewish Thoughts (New York: Oxford University Press, 1920), 11 .

${ }^{5}$ Wilson, 215. 
home, according to the Jewish mindset. The example of Abraham shows that he was the one responsible for leading the worship and interceding for his whole household. ${ }^{1}$

God requested Moses to build Him a sanctuary (Exod 25:8). This is the first time that a place for corporate worship is mentioned in the Bible. The fact that the nation leaving Egyptian bondage would have a place for corporate worship, does not necessarily mean that such practices of corporate worship would replace worship in the family.

Years after the tabernacle was built Moses also instructed the children of Israel regarding their responsibilities pertaining to the teaching of God's commandments. Parents needed to take heed of these sacred instructions themselves as well as treat them as a priority in the home with their children and wherever they went (Deut 6:6-9).

The sanctuary offered an audio-visual illustration of the plan of salvation through the sacrificial system, as the morning and evening sacrifices were clear acts of worship per se. The altar and the sacrifices were intimately connected with the lives of the people as they approached God, either individually, as a family, or in a corporate setting.

The story behind the birth of Samuel (1 Samuel) and his faithful service to the Lord leads to the conclusion that Hannah was diligent in teaching the religious principles to her son at home, before committing him to live and serve with the priest in the temple at Shiloh. ${ }^{2}$

\footnotetext{
${ }^{1}$ White, Patriarchs and Prophets, 141-142.

${ }^{2}$ Ibid., 570-572.
} 
Later on Samuel introduced the school of the prophets in Israel. The teachings of God's commands were taught at those schools as an aid to the home. ${ }^{1}$ They were not to replace the family home as the primary focal point for teaching religion to the children.

David himself expressed in Ps 78:5-6 that the children should always be taught about God's statutes and know Him as their God, throughout all generations. This fit perfectly with what Moses had counseled the Israelites in Deut 6.

The story of Job needs to be considered. The Bible states that he continually prayed for his family, offered sacrifices for them, and invited his household and "summoned his children to appear in his house, where some form of religious ceremony was conducted."2 Job's concern for his children and his love and respect for God led him to the practice of customary religious services. The emphasis in this text is Job's intercessory ministry for his children.

From the patriarchs' experiences it is possible to draw the important conclusion that they worshipped God with their families. The concepts of such worship include offering, bringing something to the Lord (Cain and Abel); gratitude and faith (Noah); faith and the desire to reach out for others (Abraham); togetherness with family (Jacob); diligent religious teaching of children (Hannah to Samuel); and concern for children, love and respect for God (Job). Of pivotal importance and prominence in the Old Testament is the idea of altar-building, creating a special place to worship God. ${ }^{3}$ These worship elements present in patriarchal forms of worship, together with their families, form a rich

${ }^{1}$ Ellen G. White, Education (Mountain View, CA: Pacific Press, 1952), 45-47.

2"Sanctified them," SDA Bible Commentary, ed. Francis D. Nichol (Washington, DC: Review and Herald, 1953-57), 3:500.

${ }^{3}$ Youngberg and Youngberg, 23. 
heritage of characteristics for Christian homes to emulate as they practice family worship today.

\section{Family Worship in the New Testament}

The New Testament does not provide a clear description of the practice of family worship. However, there are some indications that such practices were observed by the followers of Christ in this time of His church.

The first leaders of the Christian church were Jews and they all were familiar with the order of service and religious practices of the Synagogue, which certainly influenced the church. Adolf Harnack adds, "Moreover, we know that among the Gentile Christians the order of public worship and private and family discipline in matters of religion and morality, took form in accordance with the Jewish [Jewish Christian] models."1

The New Testament shows that the Christian church was born in the homes of the followers of Christ. ${ }^{2}$ In the believers' homes they prayed, studied the Scriptures, and praised God. Homes were the ideal places in which people could meet and worship the Lord. $^{3}$ Specific reasons are noted for this situation. The early Christian church was not an organized body. Christians lived in a hostile culture, and believers feared persecution. $^{4}$

${ }^{1}$ Adolf Harnack, Bible Reading in the Early Church, trans. J. R. Wilkinson (London: Williams \& Norgate, 1912), 32.

${ }^{2}$ Anna Laura and Edward W. Gebhard, Guideposts to Creative Family Worship (Nashville, TN: Abingdon Press, 1959), 13. 169-170.

${ }^{3}$ Gerhard Delling, Worship in the New Testament (Philadelphia, PA: Westminster, 1962),

${ }^{4}$ Robert E. Webber, ed., The Complete Library of Christian Worship (Peabody, MA: Hendrickson Publishers, 1993), 170. 
The early Christian church did not have any building for the believers to gather to worship. The buildings created for Christian worship appeared only after 313 A.D. when Christianity became officially accepted ${ }^{1}$ and buildings erected for the purpose of worship "multiplied after the cessation of persecution in the fore part of the fourth century."

Regardless of these conditions, the believers' homes were the central places where they could practice and develop their religious activities. ${ }^{3}$

In his writings, the apostle Paul addressed some believers who hosted a "church" in their homes. He mentions Priscilla and Aquila in Ephesus (Rom 16:5; 1 Cor 16:19); Nymphas in Laodicea (Col 4:15); and Philemon (Phlm 2). The New Bible Dictionary suggests, "Either that the household was regarded as a church in itself, or that the church in a given locality met within the scope of one household's hospitality." In addition to this reality, Paul mentions that a 'house' was also the place where corporate worship took place (2 Cor 5:1, 2) and he called the church of his time a "household of faith" (Gal $6: 10)$.

The example of Timothy is worth mentioning. Paul exhorts him to continue to pursue the learning of spiritual things and commends him as knowing the Scriptures since his infancy (II Tim 3:14-15). Both his grandmother Lois and mother Eunice are noted as

${ }^{1}$ Michael Collins and Matthew A. Price, The Story of Christianity (London: Dorling Kindersley, 1999), 40. $1: 204$.

${ }^{2}$ Kenneth Scott Latourette, A History of Christianity (New York, NY: Harper, 1953),

${ }^{3}$ Phillip Comfort, "Worship in the House Churches," in The Complete Library of Christian Worship, 2 vols., ed. Robert E. Webber (Peabody, MA: Hendrickson Publishers, 1993), 1:157-158.

${ }^{4}$ D. W. B. Robinson, "Family Household," New Bible Dictionary, ed. James D. Douglas (Wheaton, IL: Tyndale, 1992), 372. 
having exercised a great deal of influence on Timothy's spiritual life (II Tim 1:5) because they invested time studying the Scriptures with him since his childhood. ${ }^{1}$ This illustrates that meticulous religious instruction was present in their home.

The New Testament believers also followed the practice of "breaking bread from house to house" (Acts 2:46) in their daily religious activities. All of these suggest that both the family and the home were the core of religious activity for the early Christians.

\section{Family Worship in Christian Literature}

The amount of existing literature that deals with the practice of family worship or home spiritual instruction during the first fifteen centuries of the Christian church is extremely limited. ${ }^{2}$ One possible reason is that printing would become reality only centuries later and books were expensive. Literacy levels were low but some individuals and families had copies of the Scriptures that were translated into the vernacular. Bible reading by individuals or groups was encouraged, due to the attitude of the church in those days. ${ }^{3}$ Therefore, some available writings show how this practice must have been kept alive in Christian households and played a special role in their lives.

${ }^{1}$ White, Acts of the Apositles, 203-204.

${ }^{2}$ L. Edgel Phillips, An Explanatory Study of the Aims and Methods of Family Worship in the Seventh-day Adventist Church (Ph.D. dissertation, Andrews University, 1992), 24.

${ }^{3}$ Latourette, 1:210-211. 


\section{The First Christian Centuries}

The Didache, composed in Syria late in the first century and which was accepted as the "Teachings of the Twelve Apostles," played a major role among the early Christian believers, influencing their Christian ceremonies and their religious life at home. ${ }^{1}$

According to Latourette ${ }^{2}$ the writings ascribed to Dionysius the Areopagite, a convert of Paul mentioned in Acts 17:34, helped to create an atmosphere for contemplation and prayer which was chiefly promoted by family and private reading of religious materials, including portions of the Scriptures. All of these were very prominent in the fourth and fifth centuries. Conversely, these writings of the 'Pseudo' Dionysius were closely associated with mysticism and became very influential in Christian thought, mainly because the supposed author was closely associated with the apostle Paul. They exercised an effect even on Thomas Aquinas many centuries later.

During this time, many other works of a devotional nature continued to be written and were circulated. Augustine's Confessions, written in the fourth century, have been read extensively over the centuries. ${ }^{3}$ They have created an impact in the lives of those who adopted the Christian religion as their own. They are mentioned as a source of inspiration and private devotion, leading Julianus Pomerius to write The Contemplative $\mathrm{Life}^{4}$ either late in the fifth or early in the sixth century.

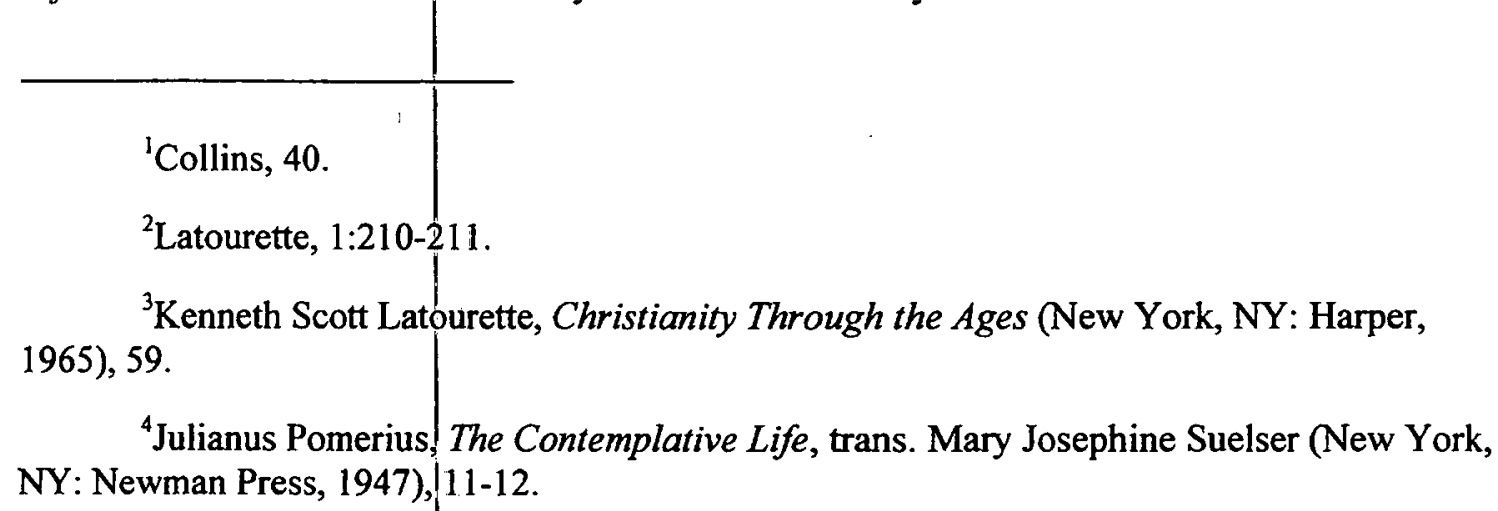
1965), 59.

${ }^{4}$ Julianus Pomerius, The Contemplative Life, trans. Mary Josephine Suelser (New York, NY: Newman Press, 1947), 11-12. 
There is some literature that focuses on both individual and corporate worship during this period of time, but does not necessarily address the subject of family worship. One can suppose that the vigorous faith of the Christians of this period would surely indicate such a practice'in their family circles. Family was still pre-eminent as a basis of society. For Christians, the well-being of their families was essential in order to preserve them from the influences of worldly society and for instruction in spiritual beliefs.

One of the accomplishments of this time was the translation of the Bible into the Latin language. The Vulgate by Jerome, late in the fourth century, was made the standard version of the Bible by the Roman Catholic Church and the only true and acceptable translation of the Scriptures.

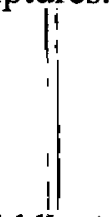

During the Middle Ages

During the Middle Ages at the Council of Trent in 1547-1548 the Jerome Vulgate translation was enforcediby the Roman Catholic Church and declared authentic. It was "ordered that no one should presume to interpret the Bible contrary to the sense authorized by the Church.,2 Such an attitude led to the prohibition of private Bible reading. ${ }^{3}$ Harnack adds that in the bull "Unigenitus" in the year 1713, private Bible reading by lay members was again discouraged by the Church, because the Church 'Harnack, 4.

${ }^{2}$ Latourette, $A$ History of Christianity, 2:868.

${ }^{3}$ J. M. Cramp, A Text Book of Popery: A Brief History of the Council of Trent (London: Houston and Stoneman, 1851), 85. 
claimed it was the only institution having the right to "regulate the use of the Bible by laity-that is, to limit and to forbid it."1

During this dark period, the priests were placed in the position of organizing worship, which was transferred from the family sphere to the setting of the church. Increased importance was given to the altar and the sacraments, especially the Eucharist or the Mass, at the expense of the preaching of the Word. The authority of the priest was emphasized and he was placed in charge of all religious activity. He also acted as an intercessor between humanity and God. ${ }^{2}$ These decisions undermined the "priesthood of all believers," as preached and held high by the Reformers. ${ }^{3}$ Pourrat claims, "The priest is powerful, for he brings down from heaven divine grace upon the sacrifice by invoking the Holy Spirit; by baptismal regeneration he remits sins and cleanses souls; and by his prayers he makes God propitious not only to the living, but also to the dead."4

The Waldenses of Piedmont were persecuted because of their reluctance to accept changes in the form of pure Bible teachings regarding worship that were gradually taking place in the twelfth century. However they remained faithful to the task of educating their children and teaching them to read from the Bible. "The purpose was to transmit faith, but in so doing, the rudiments of literacy were passed on too."5 They also regarded

${ }^{1}$ Harnack, 5.

${ }^{2}$ Latourette, A History of Christianity, 1:529.

${ }^{3}$ Ibid., 2:869-871.

${ }^{4}$ P. Pourrat, Christian Spirituality, 4 vols., trans. W. H. Mitchell and S. P. Jacques (New York, NY: P. J. Kennedy and Sons, 1922), 1:106.

${ }^{5}$ Prescott Stevens, The Waldensian Story: A Study in Faith, Intolerance and Survival (Lewes, Sussex: The Book Guild, 1998), 73. 
the preaching of the Word as "a solemn duty." The Waldensian families owned a Bible or a devotional book and made strong efforts "to instill the faith in children and in new converts."

The Waldenses valued the importance of a close relationship between the home, church, and school, especially in religious matters. The rule was that each of their churches was supposed to have a school attached to it, with the main purpose of teaching religious knowledge to the children. ${ }^{3}$ The important period for private worship was at the time of the evening meal. The father prayed for the food and the family read from Scripture, then they would say the Lord's Prayer together. Immediately after eating, they would stand holding hands and recite $\operatorname{Rev} 7: 12 .^{4}$

\section{During the Reformers' Time}

Luther valued the importance of the family. His marriage to Katherine von Bora provided them both with a stable home where several children were born. Luther had a concern for the spiritual well-being of the children. He wrote a Small Catechism designed for children and he also motivated others to write religious materials for children, too. ${ }^{5}$

${ }^{1}$ Ibid., 84.

${ }^{2}$ Ibid., 80 .

${ }^{3}$ Ibid., 165.

${ }^{4}$ Giorgio Tourn, The Waldensians: The First 800 Years (1174-1974), trans Camilo P. Merlino (Torino, Italy: Claudiana Beatrice, 1980), 39.

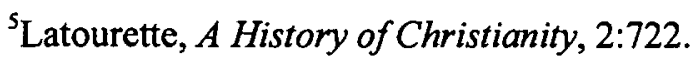


Luther emphasized education in the family, with special attention to religious education. ${ }^{1}$ Cecil Myers cites Martin Luther as saying, "The home is the God-ordained place for training in Christian character." $\mathrm{He}$ also promoted the production of religious literature for children. Luther's "Table Talk" with his family during meal time also attracted the attention of some of his students. ${ }^{3}$ Prayers for morning and evening meals were customary, ${ }^{4}$ and were, in a sense, a form of family worship. Luther strongly believed in the "priesthood of all believers," (1 Pet 2:5, 9; Rev 1:6; 5:10; 20:6) allowing freedom to study the Bible and to worship, although this was not tolerated by the dominant church of the day.

Calvin, in the sixteenth century, emphasized the importance of religious instruction for children. He was responsible for the religious transformation that occurred in Geneva, with the founding of a Christian school. This later became the University of Geneva, ${ }^{5}$ providing a Christian environment and education for children. ${ }^{6}$ Calvin encouraged "parents and family heads leading their households in worship."7 His prayers were compiled and formatted as a family devotional liturgy by Jean Rivery in

${ }^{1}$ Gangel, 139-140.

${ }^{2}$ T. Cecil Myers, Happiness Is Still Home Made (Waco, TX: Word Books, 1976), 19.

${ }^{3}$ Latourette, A History of Christianity, 2:722.

${ }^{4}$ Ibid.

${ }^{5}$ Ibid., 758.

${ }^{6}$ Peter Y. DeJong, "Calvin's Contribution to Christian Education," Calvin Theological Journal (November 1967): 200.

${ }^{7}$ Elsie Anne McKee, trans. and ed., John Calvin Writings on Pastoral Piety (New York, NY: Paulist Press, 2001), 210. 
1561 , and were supposed to be used during the morning and evening worship periods. ${ }^{1}$ In his catechism Calvin included prayers with words for children, adults, and the family in their devotional life. ${ }^{2}$

During the time of the Reformation another movement arose named the Anabaptists. They believed in a second baptism, as they opposed infant baptism. ${ }^{3}$ For this reason they were persecuted by the Catholics and Protestants. ${ }^{4}$ They devoted time to study of the Bible, had a simple form of worship, held high standards of morality based on their desire to resemble the teachings of the Sermon of the Mount, and opposed war and military service. ${ }^{5}$ The Anabaptists did not believe in salvation by works, they adopted temperance as a lifestyle, were zealous missionaries, and have been noted as being honest and peaceful. ${ }^{6}$ They exercised great influence among the Independents and Baptists in the eighteenth to twentieth centuries. ${ }^{7}$ Fierce persecution forced them to worship in hiding. Death sentences pronounced on them were usually carried out by drowning, beheading, or burning. ${ }^{8}$ The largest group of Anabaptists who resisted persecution was the Mennonites, who were named after their leader Menno Simons.

'Ibid.

${ }^{2}$ Ibid., 30 .

${ }^{3}$ Latourette, A History of Christianity, 2:779.

${ }^{4}$ Collins, 138.

${ }^{5}$ Latourette, A History of Christianity, 2:779.

${ }^{6} \mathrm{Ibid}$.

${ }^{7}$ Ibid., 779-780.

${ }^{8}$ Ibid., 782. 
For the Anabaptists, religion was a personal matter. They held secret meetings in private houses day and night. There they studied the Bible, had exhortations and testimonies, sang hymns, mostly of their own composition, and aimed to restore Christianity as more of an individual responsibility. ${ }^{1}$ Religion was carefully taught at home and they made this a matter of spiritual growth for their children. ${ }^{2}$

A movement called the Puritans emerged early in the seventeenth century with the desire to "purify" the Church of England from its corrupt connections with Roman Catholicism. ${ }^{3}$ They also believed in the "priesthood of all believers" and upheld the importance of the laws of God and that Scriptures reveal that through obedience, God's promises could be imparted to humanity. ${ }^{4}$ This inspired Tyndale to dedicate himself to translating the Bible, so that people would be enabled to read it and know God's law, making its reading easier so that even "a boy that driveth the plough" could understand it. $^{5}$

Puritans emphasized Bible reading and held religious services in their homes. ${ }^{6}$ One of the greatest achievements of this period was the King James Version of the Bible,

'C. Henry Smith, The Story of the Mennonites (Newton, KS: Mennonite Publication Office, 1957), 20-21.

${ }^{2}$ Ibid., 318.

${ }^{3}$ Latourette, $A$ History of Christianity, 2:813.

${ }^{4}$ Ibid., 814.

${ }^{5}$ Collins, 142.

${ }^{6}$ Latourette, A History of Christianity, 2:817. 
ordered by James I. The aim was for it to become the standard Bible version for church services as well as use in the homes of the people and by private individuals. ${ }^{1}$

William Maxwell notes that the importance of family worship was given priority in the Church of Scotland from 1640 onwards. Families were encouraged to hold family worship in the form of prayers and psalms in the morning and evening. Those who were responsible for the church s pulpit were supposed to present the importance of such family practices. Increased value was placed on religious activity in the homes of believers. ${ }^{2}$ Henderson notes that family worship became a custom for the church members. ${ }^{3}$ People were given access to books that were distributed for the promotion of family worship. These consisted of Bible readings and psalms for singing. The Privy Council endorsed the Book of Common Prayer for family worship in $1680 .^{4}$

It is interesting to note the remarks of Marsden in regard to the devotion of the original Puritans, "They read the Scriptures and books of piety and remembered to keep the Sabbath day. They prayed in their families, and they prayed alone."5

In the eighteenth century the world saw the rise of Methodism, mainly inspired by the dedicated and inspiring work of Susanna Wesley. She instructed her family well in the Lord and gave her children the best possible Christian and religious education. She

${ }^{1}$ Ibid.

${ }^{2}$ William D. Maxwell, A History of Worship in the Church of Scotland (London: Oxford University Press, 1955), 107-108.

${ }^{3}$ G. D. Henderson, Religious Life in the Seventeenth-Century Scotland (London: Cambridge University Press, 1937), 8-12.

${ }^{4}$ Ibid., 124.

${ }^{5}$ J. B. Marsden, The History of the Early Puritans from the Reformation to the Civil War in 1642 (London: Hamilton, Addams, and Sons, 1850), 340. 
motivated her children and John and Charles Wesley became prominent preachers. Susanna Wesley has been rightly called the mother of Methodism. ${ }^{1}$ Anna Laura and Edward Gebhard attest to 'this fact, adding that "Methodism's founder was born in the Epworth rectory, where an inspired mother hid the leaven of spiritual truth in the minds of her children." 2

The influence received at home inspired the ministry of John Wesley to value the importance of religious education for children. He admonished parents to "have some time every day for reading, meditation and prayers. ... Neither should any day pass without family prayers."3 Phillips affirms that Wesley emphasized the need for prayer and participation in family worship as he also encouraged the training of children to pray. $^{4}$

Late in the seventeenth century in Germany, Philip Jakob Spener and August Hermann Francke began a movement called Pietism. They focused on a more relational Christian experience with God, turning away from rigid orthodoxy and liturgy. They influenced the Moravian Church and Count Zinzendorf in the eighteenth century. ${ }^{5}$ Zinzendorf established his church on his property and founded the village of Herrnhut. There he led a devoted community in practical Christianity. He formed cells

\footnotetext{
${ }^{1}$ Richard Morgan Cameron, The Rise of Methodism (New York, NY: Philosophical Library, 1954), 17.

${ }^{2}$ Gebhard, Guideposts to Creative Family Worship, 14. 203-207.

${ }^{3}$ The Works of John Wesley, 32 vols. (London: Wesley-Methodist Book Room, n.d.), 20:

${ }^{4}$ Phillips, 31 .

${ }^{5}$ Kenneth O. Gangel and James C. Wilhoit, The Christian Educator's Handbook on Spiritual Formation (Grand Rapids, MI: Baker, 1994), 297.
} 
for prayer and focused on personal devotion to God. ${ }^{1}$ Zinzendorf emphasized religious education because he loved and admired children. He wrote a catechism for children entitled The Pure Milk of the Doctrine of Jesus ${ }^{2}$ and the Moravian Text Book which was a manual for individual and family daily devotions. These inspired not only the Moravians, but "many thousands of Christians of all persuasions"3 as well.

The Influence of Puritanism in the New World

Fleeing from religious persecution in Europe, ${ }^{4}$ Protestant groups of Anabaptists, Moravian, Pietists, and Puritans who had settled in the new colonies brought with them the passion to worship God according to their conscience. They caused the "First Great Awakening" in America. The writings and sermons of Jonathan Edwards stirred peoples' and preachers' hearts, promoting the spread of the Gospel in New England. ${ }^{5}$

The practice of family worship is evident since the arrival of Puritanism in New England in the seventeen century. John Eliot and Cotton Mather had a major influence in the religious life of the people. The New Englanders' devotional life included the reading of the Bible and other spiritual books, meditation, prayer, psalm singing, 1962), 65 .

${ }^{1}$ A. J. Lewis, Zinzendorf: The Ecumenical Pioneer (Philadelphia, PA: Westminster Press,

${ }^{2}$ Ibid., 172 .

${ }^{3}$ Ibid., 178.

${ }^{4}$ Collins, 169.

${ }^{5}$ Ibid., 168. 
thanksgiving at meals, and even the keeping of a diary or other forms of spiritual records. For them the family was a "little church" and the father was a priest to his flock. ${ }^{1}$

Even with all these family religious practices, devout New Englanders complained that people were not praying "morning and evening" or reading the Scripture daily in their private spiritual devotions. This caused the calling of a Reforming Synod in 1679 , with the purpose of improving the spirituality of the people. ${ }^{2}$

The Presbyterians launched an effort to promote family worship among their members through the publication of the book Thoughts on Family Worship in 1847 . In this book, family devotions were emphasized and seen as a means of promoting salvation for the entire family. ${ }^{3}$

According to Louis Weeks, by the end of the nineteenth century Presbyterian homes in the United States were places where family members were involved in regular nightly study of the Bible, prayer, and thanksgiving before meals. ${ }^{4}$ Mackay adds that Presbyterian families had a regular morning and evening time set aside to read the Bible, and that parents and children prayed together. At home, the father acted as the priest of the household, reading the Bible and offering intercessory prayers for his family. ${ }^{5}$

${ }^{1}$ Charles E. Hambrick-Stowe, The Practice of Piety: Puritan Devotional Disciplines in Seventeenth Century New England (Chapel Hill, NC: University of North Carolina Press, 1982), 136-150.

${ }^{2}$ Ibid., 136.

${ }^{3}$ James W. Alexander, Thoughts on Family Worship (Philadelphia, PA: Presbyterian Board of Education, 1847), 236.

${ }^{4}$ Loius B. Weeks, To Be a Presbyterian (Atlanta, GA: John Knox Press, 1983), 88.

${ }^{5}$ John A. Mackay, The Presbyterian Way of Life (Englewood Cliffs, NJ: Prentice-Hall, 1960), 160. 
Walter Lingle notes that since 1862 the Presbyterian Church has stressed the importance of developing an effective children's ministry. Families have been instructed about the need for mutual cooperation between home and church in order to train their children about religion. ${ }^{1}$

Later in that century, a "Family Altar" program was designed to promote family worship, in which family members were encouraged to formally report their piety. This seems to have caused the weakening of the enthusiasm for family devotions among Presbyterians. $^{2}$

Southern Baptists encourage their members to teach religion to their children and to practice family worship. Norman Cox sees the home and family "as the primary source of religious character growth." $\mathrm{He}$ further adds, "No church, nation, or civilization ever rises higher than the spirit of religious reverence and worship that prevails in the home life of its people."4 J. David Prewitt agrees that home should be the first Christian educator where the Bible is read, prayers offered, and participation in church activities promoted, but none of these exclude the parents' responsibility to teach religion to their children by their own example. ${ }^{5}$

\footnotetext{
${ }^{1}$ Walter E. Lingle, Presbyterians: Their History and Beliefs, rev. ed. (Richmond, VA: John Knox Press, 1960), 103.

${ }^{2}$ Weeks, 88 .

${ }^{3}$ Norman Cox, “Why Have Family Worship?” Home Life, May 1947, 21.

${ }^{4}$ Ibid.

${ }^{5}$ J. David Prewitt, "The Role of the Home in Christian Education," Church Training, December 1971, 22.
} 
Baptists have emphasized family worship by encouraging families to erect family altars as "specific gatherings of the family for prayer and Bible study."

The importance of religious instruction in the home for Episcopalians is stated in the 1892 Episcopal Pastoral Letter. It states, "The hearth of the home is the sacred altar, at least, of all religion, all law, and all order." ${ }^{2}$ The Episcopal Church has always encouraged the use of the Book of Common Prayer for its members as part of their private devotions at home or at church, which includes special prayers in the homes. ${ }^{3}$

The Mormons have written a curriculum entitled Family Hole Evening which is published annually in different forms by the Corporation of the President of the Church of Jesus Christ of Latter-day Saints. It gives ideas and promotes family worship. ${ }^{4}$ The views and beliefs of Seventh-day Adventists concerning family worship are best described in the writings of Ellen G. White, who was a prominent leader and co-founder of the Seventh-day Adventist Church. Her views are presented in the next section.

\section{Family Worship in the Writings of Ellen G. White}

Ellen White writes extensively about family worship. She says that the time set aside by Christian families for family worship "should be the sweetest and most helpful

'Bill J. Leonard, "Southern Baptist: Family as Witness of Grace in the Community," in Faith Traditions \& the Family, ed. Phyllis D. Airhart and Margareth Lamberts Bendroth (Louisville, KY: Westminster John Knox Press, 1996), 13.

${ }^{2}$ Joanna Bowen Gillespie, "Episcopal: Family as the Nursery of Church and Society," in Faith Traditions \& the Family, ed. Phyllis D. Airhart and Margareth Lamberts Bendroth (Louisville, KY: Westminster John Knox Press, 1996), 144.

${ }^{3}$ Marion J. Hatchett, Commentary on the American Prayer Book (New York, NY: Seabury Press, 1980), 147-148.

${ }^{4}$ David Leslie Dickerman, Family Worship in the Free-Church Tradition (D.Min. dissertation, Hartford Seminary, 1979), 81. 
of the day." She also refers to this time as "the most precious, most sacred, and the happiest hour of the day." The purpose of this section is to present her views and suggestions about family worship.

\section{Daily Activity}

Ellen White points out the fact that God intended the home to be the first school for children. Parents are the first instructors in preparing their children to be of service at home, in society, and also in the church. ${ }^{3}$ In the home setting, children should be educated about discipline, respect, secular knowledge, and especially about the importance of religion. ${ }^{4}$

White counsels that family worship should be a consistent activity as part of the family daily Christian experience. "In every family there should be a fixed time for morning and evening worship. How appropriate it is for the parents to gather their children about them before the fast is broken, to thank the heavenly Father for His protection during the night, and to ask Him for His help and guidance during the day!",5

Such times should be invitations for God's angels ${ }^{6}$ to join in holy adoration with the family and to witness His grace and love bestowed upon the worshippers. 1930), 341.

${ }^{1}$ Ellen G. White, Messages to Young People (Washington, DC: Review and Herald,

${ }^{2}$ Ibid., 342.

${ }^{3}$ White, Child Guidance, 480-481.

${ }^{4}$ White, Testimonies, 5:424.

${ }^{5}$ Ibid., 7:43.

${ }^{6}$ White, Education, 186. 
Family worship should be conducted faithfully as a regular daily activity in the home. Parents ought not to allow the problems and challenges of their busy work schedules to interfere with this spiritual time with their children. ${ }^{1}$

\section{Structured Program}

Family worship needs to follow a structure and it should be designed to involve all participants. It needs to be meaningful for every age group so that it can even be interesting for the children. ${ }^{2}$ This requires the parents to plan and prepare to make it "brief and full of life." God is dishonored when it is made dry and irksome. ${ }^{4}$ One of the purposes of this spiritual activity in the home is to teach object lessons to children about worshipping God. ${ }^{5}$ It should present the message in a clearer way to the family, involving the participation of all family members, including the children. ${ }^{6}$

The reading of the Scriptures must have a special place in the family worship program. The selection of the scripture needs to be well chosen and simple. ${ }^{7}$ Its contents need to be applicable to family life and be interesting, practical, and easily understood by the participants. It should provide a lesson that can motivate love for the Word of God

${ }^{1}$ White, Ministry of Healing, 393.

${ }^{2}$ White, Testimonies, 7:43.

${ }^{3}$ White, Messages to Young People, 341 .

${ }^{4}$ White, Testimonies, 7:43

${ }^{5}$ White, Testimonies, 6:354.

${ }^{6}$ White, Education, 186.

${ }^{7}$ White, Christian Service, 210. 
and inspire the family during the day, ${ }^{1}$ impressing the minds and hearts of the participants about the love and protection of the Heavenly Father:

Children should be given the opportunity to participate in selecting ${ }^{2}$ and reading the Scriptures. ${ }^{3}$ This will cause them to be involved in the family service and feel valued as they learn to respect and appreciate God's promises to His people. It also allows them to make a personal application of the Scriptures to their lives. The selected texts should provoke questions from the children and the parents can answer them by making practical applications, thus drawing the young minds closer to God. ${ }^{4}$

Ellen White mentions the importance of teaching children the law of God during family worship. Children are encouraged to learn and creatively repeat God's law, allowing them to retain the message in their minds even in the later stages of their lives. ${ }^{5}$

Prayer has a special place in family worship. Prayer is the life of the human soul ${ }^{6}$ and "is communion with God, the Fountain of wisdom, the Source of strength, and peace, and happiness." 7 Ellen White says that every Christian home should be a place of prayer. "In every Christian home God should be honored by morning and evening sacrifices of

'White, Child Guidance, 522.

${ }^{2}$ Ibid.

${ }^{3}$ White, Testimonies, 7:43.

${ }^{4}$ White, Child Guidance, 522.

${ }^{5}$ Ellen G. White, Evangelism (Washington, DC: Review and Herald, 1974), 499-500.

${ }^{6}$ Ellen G. White, Steps to Christ (Mountain View, CA: Pacific Press, 1956), 98.

${ }^{7}$ White, Testimonies, 7:42. 
prayer and praise." Parents are reminded that their prayers for their family, offered to God in family worship, are like sweet incense carried by the heavenly angels to His throne of grace and returned to the family in the form of blessings. ${ }^{2}$

The home is the most suitable place to pray for the family. ${ }^{3}$ Our joys and concerns are shared in the family circle. Prayer needs to be part of family worship and it should be short and right to the point. ${ }^{4}$ Parents are encouraged to pray with their children and to teach their children how to pray, ${ }^{5}$ by allowing them to pray in family worship. ${ }^{6}$

Ellen White says that the name of God is exalted through songs of praise and "singing is a part of the worship of God."7 She mentions music as an act of praise and "one of the most effective means of impressing the heart with spiritual truth.... As part of a religious service, singing is as much an act of worship as is prayer." ${ }^{, 8}$ Music is an important element in the family worship program and children should join in the singing as a part of their adoration to God in the family setting. ${ }^{1}$

Ellen White encourages the use of musical instruments during family worship. During this part special attention ought to be given to God's law, as the children can learn

${ }^{1}$ Ellen G. White, Counsels to Parents, Teachers, and Students (Mountain View, CA: Pacific Press, 1943), 110.

${ }^{2}$ Ellen G. White, Selected Messages, 3 vols. (Washington, DC: Review and Herald, 1958), 2:440.

${ }^{3}$ White, Testimonies, 1:145-46.

${ }^{4}$ White, Christian Service, 210.

${ }^{5}$ White, Adventist Home, 317.

${ }^{6}$ White, Messages to Young People, 341.

${ }^{7}$ White, Evangelism, 506.

${ }^{8}$ White, Child Guidance, 523. 
it by singing, just like Moses taught the children of Israel. ${ }^{2}$ She adds that parents should use their creativity to make music and singing an attractive part of their family worship. "Let us do everything in our power to make music in our homes, so that God may come in."3

\section{Parents' Responsibility}

Ellen White makes clear the fact that parents are responsible before God for making provision for teaching religion and building their children's characters at home. ${ }^{4}$ They are to present God's goodness and greatness to their children through the teaching of the law and also through songs, prayer, and spiritual lessons from the Word of God. ${ }^{5}$

Parents need to realize that home is their first missionary field in the proper training of their children. ${ }^{6}$ The influence exercised by the activities and teachings of the home on their children's lives is a lasting one. ${ }^{7}$ The Bible attests to this fact, as God says, "These commandments that I give you today are to be upon your hearts. Impress them on your children" (Deut 6:6-7).

\footnotetext{
'White, Testimonies, 4:314.

${ }^{2}$ White, Evangelism, 499-500.

${ }^{3}$ Ibid., 500.

${ }^{4}$ White, Adventist Home, 318-319.

${ }^{5}$ Ellen G. White, Fundamentals of Christian Education (Nashville, TN: Southern

${ }^{6}$ White, Testimonies, 6:429.

${ }^{7}$ White, Counsels to Parents, Teachers, and Students, 131.
} Publishing Assn., 1923), 442. 
God desired that His law and statutes should be taught at home first where the children should learn how to love and respect Him as their God. ${ }^{1}$ Ellen White refers to the worship hour as the most appropriate time for children to learn to love the Word of God. ${ }^{2}$ She also asserts that the whole family should be gathered together to take part in family worship. She calls it the "family altar" and "altar of prayer."

Parents should be aware that the heavenly universe beholds those families who practice family worship, because heaven is interested in the spiritual well-being of the family. ${ }^{4}$ Parents should make this activity a daily priority in their homes, with their entire household. They should not leave home to work or enter into a night of sleep without this sacred moment of worship with their family. ${ }^{5}$

\section{The Father as a Priest}

Ellen White says that the father is entrusted to be the priest of his family. He is the one who is responsible before the Lord for bringing his entire family to God's altar, making provision for their spiritual health and growth. ${ }^{6}$ He should lead the family to develop a personal knowledge of God and make intercession by confessing his and their sins. His position in the home is to represent the "Divine Lawgiver," laboring together

\footnotetext{
${ }^{1}$ White, Patriarchs and Prophets, 143.

${ }^{2}$ White, Education, 186.

${ }^{3}$ White, Selected Messages, 2:440.

"'Incense Represents Blood of Atonement," SDA Bible Commentary, ed. Francis D. Nichol (Washington, DC: Review and Herald, 1953-57), 7:971.

${ }^{5}$ White, Patriarchs and Prophets, 143-144.

${ }^{6}$ White, Ministry of Healing, 392-393.
} 


\section{Mother as the Queen of the Home}

Ellen White mentions the mother as a co-worker with the father in raising their children to reach their highest potential and be of service in this world. ${ }^{1}$ She calls her the 'queen of her household' and the children her subjects, by whom she can bless the world ${ }^{2}$ and that the angels do not have a higher position than that of a mother in her home. ${ }^{3}$ In the absence of the father, the mother needs to lead the family in worshipping God. ${ }^{4} \mathrm{Her}$ labor in training her children for Christ is compared to the minister's work in the pulpit. ${ }^{5}$

\section{The Role of the Church Pastor in Family Worship}

Church members regard their pastor as a caregiver, a helper, and their spiritual leader. ${ }^{6}$ The church pastor's divine calling to serve in a congregation involves providing spiritual nourishment for the people. This challenges him or her to discover the needs of the people and to help cater for their physical, emotional, and spiritual necessities. The church pastor, as the spiritual leader of a congregation, must be intimately involved in the worship life of the church. Kemp suggests that "worship creates a sense of community, of fellowship, of belonging."7 Because of that, the minister should be

\footnotetext{
${ }^{1}$ Ibid., 235-36.

${ }^{2}$ Ibid., 232-234.

${ }^{3}$ Ibid., 231.

${ }^{4}$ White, Testimonies, 1:397.

${ }^{5}$ White, Christ's Object Lessons, 359.

${ }^{6}$ Bradford Lyle, Building Relationships Through Pastoral Visitation (Valley Forge, PA:
} Judson Press, 1984), 43.

${ }^{7}$ Charles F. Kemp, The Caring Pastor (Nashville, TN: Abingdon, 1985), 136. 
foremost in promoting and supporting this spiritual activity, both in the church as a corporate practice and privately in the homes of the parishioners.

\section{The Pastor as a Preacher in Relation to Family Worship}

The pastor is responsible for leading the church members in worship regularly, week after week. This "is one of the most significant tasks pastors can do." However, the corporate worship of the church does not exclude the pastor's duty in promoting, motivating, instructing, and supporting the church's families in regard to the regular practice of family worship in their homes. The pastor needs to use his or her preaching as a powerful tool to ensure that members are aware of the blessings of family worship.

\section{The Pastor Needs to Preach about Family Worship}

The sermon is one the pastor's most efficient channels to speak to the hearts of the members and it gives the minister a golden opportunity to magnify Christ and bring people closer to Him. ${ }^{2}$ Preaching is both a powerful tool and resource that is unique to the pastor in his or her role as a spiritual leader. ${ }^{3}$ The pastor ought to be cognizant of the fact that when preaching he or she becomes the voice of God to the people. ${ }^{4}$ Knowing this, the pastor should preach about family worship in a practical way, in order to present the message more attractively. 1980), 136.

${ }^{1}$ Donald Capps, Pastoral Counseling and Preaching (Philadelphia, PA: Westminster,

${ }^{2}$ White, Testimonies, 4:314.

${ }^{3}$ Kemp, 131.

${ }^{4}$ Ellen G. White, Gospel Workers (Washington, DC: Review and Herald, 1915), 147. 
The sermon may contain some practical illustrations extracted from the minister's own family worship, instructing the congregation that every Christian family should practice family worship. ${ }^{1}$ The minister might introduce this concept by preaching or sometimes promoting it creatively from the pulpit. The pastor ought to know that the sermon needs to address people's daily needs in order to be relevant. Donald Capps suggests, "We need more sermons that attempt to address people's real problems, meet their difficulties, and answer their questions."2

Personal Testimonies

The minister's sermon "needs to reflect the insights the pastor gains from involvement in the lives of parishioners." ${ }^{.3}$ This means that the pastor ought to know his or her flock and be acquainted with them. ${ }^{4}$ Also, the pastor's family unity and religious life experience should allow the minister to "preach an effectual sermon on practical godliness." $"$ This will offer the pastor an opportunity to present to the congregation a testimony about the blessings received through his or her family worship. The pastor could introduce his or her family's testimonies in a practical way to convey this message.

\footnotetext{
'White, Child Guidance, 517.

${ }^{2}$ Capps, 14 .

${ }^{3}$ Ibid., 25.

${ }^{4}$ White, Evangelism, 346-347.

${ }^{5}$ Ellen G. White, Gospel Workers (Washington, DC: Review and Herald, 1915), 204-205.
} 


\section{Children's Story}

The children's segment of the worship service is a potential time for the pastor to introduce in a simple and attractive way, the subject of family worship. This will catch the interest of the children and also challenge the parents to practice family worship. The minister or another skillful person may model a brief family worship with the children during this time, giving them the occasion to participate and view it in a practical manner. Church members can be shown that family worship should be brief and full of life. ${ }^{1}$

\section{Illustration}

“An appropriate illustration can be extremely helpful. Illustrations can explain concepts, highlight comparative statistics and they reflect the fact that reading and understanding information is more than a matter of words." illustration as a very effective strategy in His teaching. ${ }^{3}$ The pastor could offer subtle instruction to the congregation about methods of family worship through sermon illustrations or print a story of a faith hero which relates to the topic in the church bulletin. Also, a member could share his or her experience with family worship during the service as a form of illustration. These could be ways of promoting family worship.

${ }^{1}$ White, Education, 186.

${ }^{2}$ Ashgate Publishing, "Why a Picture Isn't Always Worth a Thousand Years," 2007, www.ashgate.com/subject_area/downloads/illustrations_guide.pdf (May 21, 2007).

${ }^{3}$ White, Christ's Object Lessons, 21. 
The Counselling Pastor and Family Worship

The congregation identifies its minister as a caregiver, and members still turn to their minister in times of difficulty and crisis. "Pastors above all will know that they are at most midwives of God's grace." In situations like these, the pastor becomes a counsellor and is placed in a privileged position where people tend to be more receptive to his or her words because people facing crises need caring persons around them. ${ }^{3}$ In dealing with individuals in crisis, the pastor should communicate openness and concern for them ${ }^{4}$ since he or she should be interested in the spiritual well-being of his members. This is probably one of the reasons for which people report appreciation. They value the pastor's "ability to provide comfort, advice, and reassurance."

The pastor is in a position to initiate dialogue with members ${ }^{6}$ when he or she can talk to them openly, directly, and in private. The minister should capitalize on such situations, utilizing his or her spiritual influence to promote the concept of family worship with people facing crises or difficulties in their lives.

${ }^{1}$ Kemp, 27.

${ }^{2}$ John B. Cobb, Jr., Theology and Pastoral Care (Philadelphia, PA: Fortress, 1977), 52.

${ }^{3}$ Howard W. Stone, Crisis Counseling (Minneapolis, MN: Fortress, 1993), 31.

${ }^{4} \mathrm{Cobb}, 7$.

${ }^{5}$ Howard J. Clinebell, ed. Pastor and Parish: A Systems Approach (Philadelphia, PA: Fortress, 1977), 80.

${ }^{6}$ Lyle, 16. 


\section{The Pastor as the Spiritual Leader}

Church members expect their minister to exercise leadership in the parish, ${ }^{1}$ working closely with them to promote spiritual growth and also "to be a pastor to every member," ${ }^{2}$ catering especially to their spiritual needs. The call to ministry involves becoming such a spiritual leader that, by God's grace, the members can trust their leader and be inspired to follow the perfect example of Christ. ${ }^{3}$

People also tend to follow the example of their pastor when they sense he or she is a leader who provides inspiration, creates stability, and improves the spirituality of the congregation. ${ }^{4}$ When members perceive their pastor to be a trustworthy spiritual leader, the way is opened for effective counselling as the situation requires. In such circumstances, the pastor will listen attentively and talk about the problems or crises, while noting the spiritual condition of those being counselled. Then, if appropriate, the pastor can suggest the necessity of personal devotions and/or family worship as part of the solution to the problem. Likewise, if a family is struggling with a relationship problem, the minister might remind them of their need of a relationship with God and the importance of family worship. As Clinebell suggests, "People who play, pray, and work together, stay together." ${ }^{5}$ The influence of a good spiritual leader can be a blessing to all.

${ }^{1}$ Lyle Schaller, The Pastor and the People (Nashville, TN: Abingdon, 1986), 49.

${ }^{2}$ Ibid., 47.

${ }^{3}$ Ellen G. White, Spiritual Gifts, 4 vols. (Washington, DC: Review and Herald, 1945), 3:123. 1996), 49.

${ }^{4}$ Robert H. Pierson, So You Want to be a Leader (Hagerstown, MD: Review and Herald, ${ }^{5}$ Clinebell, 21. 


\section{Pastoral Visitation and Family Worship}

Lyle believes that pastors "cannot minister to people if we do not know them ... pastoral visitation is one of the most effective ways of knowing the parishioners." Nancy Gorsuch adds that when pastoral visitation is conducted with "the purpose of nurturing relationships and fostering faithfulness, it is in my opinion, one of the most caring acts of contemporary pastoral ministry."2

Pastors have commonly received criticism from church members for not investing enough time in pastoral visitation, ${ }^{3}$ as members expect their pastor to call around more often. However, it is also a fact that there may be misconceptions concerning pastoral availability ${ }^{4}$ to initiate a relationship with members, because of the members' perception of immediacy. It can be risky for them to think that their pastor is always available.

There is an expectation from church members that their pastor should provide one pastoral visit for every family of the church per year. ${ }^{5}$ A conscientious and organized pastor will make plans to cater for such an expectation without allowing the members to create any perception that he or she is not a busy person.

The Ministry of Pastoral Visitation and Family Worship

The pastor is in a privileged position in the matter of home pastoral visitation as he or she comes into contact with people in a variety of situations and settings. As part of

${ }^{1}$ Lyle, 10.

${ }^{2}$ Nancy J. Gorsuch, Pastoral Visitation (Minneapolis, MN: Fortress, 1999), 11.

${ }^{3}$ Schaller, 162.

${ }^{4}$ Stone, 15.

${ }^{5}$ Gorsuch, 8. 
his or her work, the minister engages in pastoral conversation with church members as a form of ministry to them. ${ }^{1}$ This allows the pastor to become more acquainted with their spiritual condition, in the intimate and familiar setting of the members' homes. Because of this, the pastor can effectively minister and help them also in the issue of family worship.

The church members' homes are probably the most appropriate places for the minister to discuss, counsel, and approach them to talk about spiritual matters. When the minister has gained member's confidence, they will open themselves to him or her and talk about their problems. Lyle suggests that people "tend to feel more at ease in their own homes and usually welcome such a time with the pastor." ${ }^{2}$ He also explains that the "home visit gives people an opportunity to ask questions about the church, scriptures, or theology that they had not felt able to voice in the church settings."

Prayer should be part of every pastoral visit. ${ }^{4}$ The pastor needs to know that "a short prayer, offered in fervor and faith, will soften the hearts of the hearers", as he or she assures the people that "to every sincere prayer an answer will come."

Praying for people when visiting them offers the minister an occasion to make them conscious of God's interest in their well-being. The pastor should introduce the topic of family worship, allowing them to sense that its practice will help them come into

${ }^{1}$ Ibid., 2.

${ }^{2}$ Lyle, 42 .

${ }^{3}$ Ibid., 43.

${ }^{4}$ Gorsuch, 18.

${ }^{5}$ White, Gospel Workers, 179.

${ }^{6}$ Ibid., 258. 
closer contact with God and that family worship aims to be the family altar where the members approach God's presence in adoration and prayer. ${ }^{1}$ People need to be instructed and realize that "the presence of God creates prayer; the absence of prayer necessitates prayer." 2

\section{Summary}

This chapter has shown that God has been worshipped from eternity by the angelic host, and that such activity was one of satisfaction and happiness for the created beings as they revered their Creator in a perfect face-to-face relationship. Sin originated in Lucifer's heart because of his intention to usurp the worship rights that belonged to God alone. Such an attitude disrupted the happy bond between God and the angels who decided to follow Lucifer. As a consequence, they were expelled from heaven and the battle over worship was bought to earth, where they managed to deceive the first human couple, thus introducing sin to the human family. Because of this, the ongoing worship contest between God and Satan will continue until sin and false worship are finally destroyed.

The concept of family worship as it is presently accepted by Christians today is not mentioned in the Bible. However, the Old Testament provides evidence that family worship was practiced by the patriarchs, mainly through the symbolism of erecting altars and gathering the family around them to worship God. The New Testament provides an example of family worship mainly through the fact that Timothy is referred to as one who

\footnotetext{
${ }^{1}$ White, Testimonies, 5:424.

${ }^{2}$ Wayne E. Oates, The Presence of God in Pastoral Counseling (Waco, TX: Word, 1986), 121.
} 
received religious instruction in the home by his Christian mother Eunice and grandmother Lois. It is also mentioned that some New Testament believers hosted church worship in their houses.

It was pointed out in this chapter that there are limited resources showing the practice of family worship during the first fifteen centuries of the Christian era, which does not reflect the zeal and faith of the believers who served God and worshipped Him with their families, even when facing difficult times and persecution. In contrast, there is an abundance of literature dealing with the topic of family worship after that period.

During the period of the last eight centuries more has been written concerning family worship. In Europe, during the Dark Ages, the Waldenses took seriously the religious teaching of their children. During reformation times, Luther and Zinzendorf in Germany; Calvin in Switzerland; the Anabaptists in Switzerland, Germany, and Austria; the Moravians, the Puritans, and the Wesley movement in England and the Church of Scotland, all stressed the need of religious instruction for children in the home.

The influence of the Protestant families who migrated to America, starting in the sixteenth century, caused the first American spiritual awakening and specially influenced the spiritual life of families. It is worth noting the spiritual influence exercised in the lives of people by John Eliot, Cotton Mather, and Jonathan Edwards in New England in the seventeenth and eighteenth centuries. As a result of this awakening, different churches developed strategies and plans to motivate their members to practice communion with God, with their families, at home. This continues to this day.

Special emphasis was given in the writings of Ellen G. White, the most prominent pioneer of the Seventh-day Adventist Church, regarding the topic of family worship. Her 
views really express what Christian families should do to make family worship a daily, interesting, and sacred meeting of Christian families with God.

The last part of this chapter highlighted the important role the church pastor can play in helping the members develop and implement relevant family worship at home. The roles of the pastor as preacher, counsellor, and also in the ministry of home visitation were mentioned as specific areas of ministry that the church pastor can use as powerful tools in promoting family worship for the congregation. 


\section{CHAPTER III}

\section{FAMILY WORSHIP AT THE HAMILTON MOUNTAIN CHURCH}

\section{Introduction}

This section presents the demographics of the city of Hamilton in Ontario, Canada and of the Hamilton Mountain Seventh-day Adventist Church. It contains a brief history of the church; the rationale for the questionnaire and final evaluation survey used in the seminar; and the methodology used to design and apply those instruments. It also gives an overview of what is intended to improve the practice of family worship among the church members, assisting them to make family worship an evangelistic tool in their Christian witnessing.

\section{Demographics of the City of Hamilton}

The Hamilton Mountain Church is located in the city of Hamilton, Ontario, Canada. In 2001 the city's population was 490,268, and when combined with the metropolitan area it reached 662,401 , making Hamilton the tenth largest city in Canada. It occupies an area of 1,117.11 square kilometres. Hamilton is located in the southern part of the Ontario Province, on the western end of the Niagara Peninsula and Lake Ontario. 
According to the mid-2001 census, the city's population ethnicity was as follows: 90.7 percent Whites, 2.1 percent Asian, 1.6 percent Blacks, 1.2 percent Chinese, and 1.0 percent Mixed race. It also revealed that the gender of the population was comprised of 48.8 percent males and 51.2 percent females. Children under 5 years accounted for 5.8 percent of the reported population for that year's census.

Religious affiliation was reported in the following way: 37 percent Protestant, 35.4 percent Catholic, and 5.0 percent Other Christian. The adherents of Islam and Buddhism accounted for 1.9 percent and 0.6 percent respectively. The census did not state the religious affiliation of the remaining 20.1 percent of the population.

The history of Hamilton goes back to the $1800 \mathrm{~s},{ }^{1}$ a time when European settlers arrived after the United Empire Loyalists had come to the area, following the American Revolution and the War of 1812. In the last conflict the British defeated the Americans in the Battle of Stoney Creek, in the place now called Hamilton. In 1815, George Hamilton laid out a town site in Barton Township that eventually outstripped close rivals. Hamilton was incorporated as a Police village in 1833 and later as a city in 1846.

In the latter part of the 1800 s, Hamilton became a heavy industrial site $^{2}$ and an ambitious city, referring to itself as the Birmingham of Canada. The city workers were involved in labor activism, which in 1872 resulted in the Nine Hour Movement, urging the limitation of nine hours of work per day.

${ }^{1}$ Unless otherwise stated all historical facts and statistical information about the city of Hamilton in this section were taken from Wikipedia, "Hamilton, Ontario," 17 May 2007, http://en.wikipedia.org/wiki/Hamilton,_Ontario (February 20, 2006).

${ }^{2}$ Canada's Digital Collections, "Industrial Hamilton: A Trail to the Future," 2000, http://epe.lac-bac.gc.ca/100/205/301/ic/cdc/industrial/intro.htm (February 20, 2006). 
Natural factors like the easy access to limestone, coal deposits in Appalachia, iron ore mined from the Canadian Shield, and export markets through the Great Lakes-St. Lawrence system contributed to Hamilton growing into a hub for iron and steel production. These factors, and the amalgamation of steel enterprises, created the Steel Company of Canada in 1910 (Stelco) and Dominion Steel Casting (Dofasco) in 1912.

Hamilton was known for many years as Canada's steel city, because of its giant steel companies of Stelco and Dofasco. However, in recent years, education (McMaster University in 1930 and the foundation of its medical school in the 1960s, as well as Mohawk College in 1967), government, services, and technology sectors have made great progress in diversifying the city's economy. Today, health care has become the region's primary employer and the city receives immigrants from different parts of the world.

\section{A History of the Hamilton Mountain SDA Church}

Nearly 110 years ago, Elder E. J. Dryer and his wife came to Hamilton in 1897. Assisted by Miss Carrie Irwin and Miss Bertha Orchard, they conducted Bible studies, established a lively Sabbath School, and encouraged people to study the Word of God. ${ }^{1}$

In 1889, Elders E. J. Dryer and P. M. Howe held public campaigns on James Street South. The Lord blessed those meetings and their dedication by adding many converts to the church.

On October 15, 1899 Elder F. D. Star, the first president of Ontario Conference, organized the Hamilton Seventh-day Adventist Church with fifteen members.

${ }^{1}$ Unless otherwise stated all references to the history of the Hamilton Mountain Seventhday Adventist Church were taken from 100 Years of Adventism in Ontario, ed. Dirk Zinner (Ottawa, ON: Tri-Co Printing Inc., 1999). 
In the beginning, meetings were held in private homes, but later members met in halls. In 1913, they started to worship in a church building that was purchased from the Church of Jesus Christ of Latter-day Saints and this was dedicated on September 20, 1913.' By 1919, the church's membership had reached 119. The members sold that building and moved into Templar Hall, located in downtown Hamilton.

During 1931 to 1933, Elder O. D. Cardey held two public campaigns and fiftyseven new members were added to the church. By 1934 the church had reached 208 members. $^{2}$

On September 17, 1948, Elder Philip Moores and five church members inspected a lot on Concession Street and the church bought that lot and another next to it at once. To this day, the church remains on this property and the adjacent block of land is used for parking. ${ }^{3}$ On January 6, 1950, Mayor Jackson broke the sod for the new church.

It was under the leadership of Elder M. H. Philbrick that the church was finally built. The members of the congregation did a large share of the construction work. ${ }^{4}$

The inauguration service of the Hamilton church occurred on June 16, 1951 and it involved representatives from the Conference, Union, and General Conference levels of Seventh-day Adventists. ${ }^{5}$ The church was dedicated debt-free on December 5, $1953{ }^{6}$

${ }^{1}$ Louise Prouty, Marion Case, and Nellie Ritchie, eds. Hamilton Mountain Seventh-day Adventist Church Memories, $100^{\text {th }}$ Anniversary 1889-1999, (photocopy), 7.

${ }^{2}$ Zinner, 154.

${ }^{3}$ Prouty, 14.

${ }^{4}$ Zinner, 154.

${ }^{5}$ Prouty, 30.

${ }^{6}$ Ibid., 24. 
The first Adventist school in Hamilton opened in 1915 with Amy Gosnay as the teacher. The school operated until 1921, then it re-opened from 1931-1934, and later from 1946-1947. The school was relocated to the new church facility in September 1951.

After the inauguration of the new church, the members felt motivated to fill its empty pews with new converts through evangelism. Evangelist C. A. Reeves and Pastor Carl Wessman came to Hamilton and during 1953 fifty-nine people were baptized.'

On October 25, 1966, a new Welfare Center was officially opened by the city's Mayor Victor Copps, in a separate house on the church property. It had the goal of service to the community at large and the opening made news in a local newspaper Hamilton Spectator. ${ }^{2}$

A second church was organized on December 30, 1972 when thirty-eight people left the Hamilton church to form the Hamilton East Seventh-day Adventist Church. ${ }^{3}$ They moved into their newly built church on Bell Avenue on February 26, $1983 .{ }^{4}$

In 1973 the evangelistic meetings in Burlington resulted in the formation of a new church in the area. On October 30,1976, the Burlington group was organized into a church, becoming the second church to have branched out from the 'mother' church.

Later on, the Burlington church would join with the Oakville church to form the current Bronte Church, which is located half-way between the former two churches. ${ }^{5}$

\footnotetext{
${ }^{1}$ Ibid., 25.

${ }^{2}$ Hamilton Spectator (Hamilton, Ontario), October 4, 1966.

${ }^{3}$ Prouty, 46.

${ }^{4}$ Ibid.

${ }^{5}$ Ibid., 53.
} 
The Hamilton Mountain Church, under the leadership of Elder Eric Juriansz, who was the longest serving pastor for the church, ${ }^{1}$ was responsible for the acquisition and relocation of the school to its own building on Highway 6 South. Also during his term, a senior center and a nursing home were established for the Adventist community in Stoney Creek. This health care complex cost $\$ 4,500,000.00$ and was officially opened on November $1,1982 .^{2}$

In March 1985, the Hamilton Mountain Church said fare-well to twenty-four of its members who moved to start a new group in Grassie. A year later they were organized into the Lincoln Pioneer Church, the 'third daughter' of the Hamilton Mountain Church. ${ }^{3}$

On February 7, 1987, twenty-eight members left the Hamilton Mountain church to form a group in the health care institution in Stoney Creek. ${ }^{4}$ Then, on October 7, 1989 the Heritage Green Church, the 'fourth daughter' moved into their newly built church. ${ }^{5}$

The Hamilton Mountain Church celebrated its one hundredth anniversary in $1999^{6}$ and the Living Word Christian Fellowship group was formed in January 2001. It was organized as a church on January 24, 2004, as Hamilton Mountain's 'fifth daughter.'

${ }^{1}$ Ibid., 74.

${ }^{2}$ Charles Wilkinson, "Adventists Open Seniors' Centre," Hamilton Spectator (Hamilton, Ontario), August 28, 1982.

${ }^{3}$ Prouty, 62.

${ }^{4}$ Ibid., 63.

${ }^{5}$ Ibid., 64.

${ }^{6}$ Ibid., 71. 
After nearly 108 years since its organization, the Hamilton Mountain Church remains committed to the spiritual nurture of its members and to serving the residents of the city of Hamilton. Its plans involve playing an effective role in the spiritual lives of people and focusing on preaching the gospel of Jesus Christ, in order to prepare the whole community for His soon return.

\section{Population}

The data from the questionnaire and final evaluation survey which constitute part of this project were collected from the members of the Hamilton Mountain Seventh-day Adventist Church. The church is part of the Ontario Conference of Seventh-day Adventists, which comprises the whole Province of Ontario in Canada.

The Hamilton Mountain Church membership totaled 398 in December 31, 2005. It is a very diverse church, in culture and ethnicity. Its members come from thirty-four different nations from North, Central, and South America, Europe, Asia, Africa, Australia, and the Caribbean Islands. This multi-ethnic and cultural factor presented a positive indicator as to the importance of this project. It endeavored to address the particular needs of a church which is rich in heritage and Adventist traditions, passed down from various different backgrounds. The universal and relevant topic of family worship was introduced in the form of a seminar.

\section{Sample}

The people represented in the sample were all members of the Hamilton Mountain Church. Their addresses were collected from the church clerk's records and an attempt was made to reach those attending members of the congregation aged twelve years or 
older. Special attention was devoted to members who had children. Therefore, the church pastor hand-delivered the questionnaire to parents, as their input would help accomplish the aim of designing attractive and relevant family worships for children. Consequently, the survey was mailed to 301 people.

There was a discrepancy between the church membership of 398, and 301 surveys mailed out. This refers to the fact that although 398 people are still listed as members on the church roll, only 301 people fitted into the category of twelve years or older, and/or are attending members of the church.

The church's records show that many members have moved to or are attending other churches in the area that have branched out from the Hamilton Mountain Church, but have kept their names on the records of the 'mother' church. There is also a list of people whose membership is held at the Hamilton Mountain church, but their whereabouts could not be traced. Due to these situations, no attempt was made to reach those who were 'non-attending' members of the Hamilton Mountain church.

In order to achieve a reliable result that would reflect the positive participation of church members in this project, it was considered necessary to have a return rate of at least 60 percent of the mailed surveys. This created an anticipation of 180 returned surveys.

\section{Instrument Development}

The design of the questionnaire intended to identify the acquaintance of church members with the topic of family worship and determine their level of participation in this activity. The instrument explored the relationship between the members' aims and attitudes concerning the subject and the methods related to the practice of family worship. 
The questions were divided into four general categories, which included the demographic information, responses to the aims, responses to the attitudes, and responses to the methods that were associated with the family worship activity.

The demographic information asked for the gender, age, and level of education of each respondent. Considering that the researcher expected people from twelve years of age to answer the questionnaire, the questions in the first part of the instrument (thirty questions) were not age-related, allowing every participant to answer, based on their involvement and knowledge, as well as their interest in the subject of family worship.

In order to continue answering the questionnaire, all respondents had to answer 'Yes' to question four, "Have you ever practiced family worship in your life?" The reason for that was that the respondents were required to have practical experience with the subject which could only be assessed by their previous participation in a family worship activity. Those who answered 'No' were thanked for their participation, but asked to return the questionnaire without completing any other question.

The sixty questions of the instrument were sélected by the researcher, in close consultation with his adviser and a pre-test committee, which was comprised of eight members of the church. These members represented the gender, ethnicity, cultural, and educational levels, as well as people from one and two parent families of the church.

This pre-test committee not only counseled the researcher in regards to the questions, but they also completed the questionnaire in a private session. This exercise aimed to provide information as to whether the questions were clear and people would be able to answer them properly. During this practice some changes were made in order to enrich the clarity of the instrument before it was mailed out to the church members. 
The questions were formulated focusing on the concept and practice of family worship from a Christian perspective. They were divided into ten demographic questions, twenty questions related to the aims, seven questions related to the attitude, nineteen questions related to the methods, and four open-ended questions.

Table 1

LIST OF DEMOGRAPHICS QUESTIONS

\section{Questions}

Gender

Age

Education level

Past or present practice of family worship

Present practice of family worship

Members' adoption of family worship

Number of children in the household

Ages of the children

Weekly time spent in preparation for family worship

The way members became Seventh-day Adventists

There were five demographic questions in each part of the questionnaire. In the second part, they also tried to determine how parents adopted family worship and became Adventists, as well as the weekly time involved in planning for this activity. 
Table 2

\section{LIST OF QUESTIONS RELATED TO FAMILY WORSHIP AIMS}

Questions

Best motivation to practice family worship

Family worship gives the sense that Jesus is real in the life

Family worship promotes the religious heritage of the family

Family worship strengthens hope in the second coming of Jesus

Family worship improves appreciation for the Sabbath day

Family worship helps to claim the merits of Jesus' blood for the pardon of sins

Family worship is a time when God blesses the family

Family worship encourages family members to pray

Family worship brings family members closer to each other

Family worship sponsors respect and reverence for God's Word

Family worship promotes spiritual growth for the family

Family worship activities that create positive influence on children

Parents' perceptions of family worship most important goals for children

Parents' perceptions of positive influences of family worship on their children

Family worship develops in the children a spiritual awareness of God

Parents' wish for their children to practice family worship with their future families

Sabbath School lesson helps in the spiritual development of the children

Family worship assists in preparing children for Sabbath School

Sabbath School programs at church motivates children's participation in family worship Children's Sabbath School teachers' contribution to the spiritual growth of the children

These questions dealing with the aims of family worship attempted to achieve two purposes. First, they intended to discover the perceptions of the respondents regarding the spiritual benefits they acknowledged receiving from the practice of this spiritual activity. Second, it allowed members to reflect on whether their participation in family worship had helped them to grow individually and collectively (as a family) in their personal conviction of some specific biblical doctrines closely associated to their faith. 
Table 3

LIST OF QUESTIONS RELATED TO FAMILY WORSHIP ATTITUDES

Questions

Children's first reaction when family worship is announced

Children's attitude during family worship

Children's response at the end of family worship

Parents' evaluation about the influence of family worship in the lives of their children

Parents' observation of their children's behavior as an influence of family worship

Parents' perceived attitudes of their children caused by the influence of family worship

Influence of previous family worship that has influenced parents to have it in their homes

These questions interacted with the attitudes of participants during family worship, targeting particularly those who have children at home. They queried how parents have observed their children behaving during worship time and the influence of such a practice in the lives of their children, in relationship to God, their parents, and other children. 
Table 4

\section{LIST OF QUESTIONS RELATED TO FAMILY WORSHIP METHODS}

Questions

The frequency of family worship

Any set time for family worship

The time of the day family worship is practiced

The practice of personal devotion besides family worship

Most common place for family worship

The elements of family worship

Personal evaluation of family worship

Main reasons that sometimes affect the practice of family worship

Actions needed to improve the level and frequency of family worship

The most important parts of family worship

The length of family worship

Length or content as the most relevant factor for family worship

The individual responsible for taking initiative for family worship

Segment of family worship most appreciated by children

Segment of family worship least appreciated by children

Children active part in family worship

Activities the children are most often involved in family worship

Children leadership in family worship

Frequency of children's leadership in family worship

These questions related to the methods of family worship, inquired the

participants about the way they have conducted this activity. The questions included information about their worship program, the main person who leads it, the involvement

of the children, and the respondents' personal yearning for improving its practice.

\section{Rationale of the Questionnaire and the Final Evaluation Survey}

The questionnaire used in this project was designed with the assumption that family worship is vital as a means of promoting spiritual growth in the family, as is clearly stated in the available Christian literature. 
The questionnaire had two parts. The first part dealt with collecting general information about the subject of family worship. It specifically targeted the perception of members as to its importance. Some questions helped to measure the frequency of family worship, level of participation in the homes of members, the possible relation between private devotions and the practice of family worship, the main elements of this activity, and the reasons and motivations behind the practice of family worship.

The goal of this section was to discover the probable connection between the literacy level of the respondents and the practice of family worship. It also offered the participants the opportunity to mention some hindrances they are challenged with that may inhibit the daily practice of family worship at home. Another aim was to assess the possible relation between the ages of the participants and the practice of family worship.

The second part of the questionnaire focused on family worship with children and only those parents whose children are still living at home were requested to answer it. The main reason for this section was to discover the reactions of the children to their family worships and also the possible benefits to them. The questions dealt with the potential relationship between the amount of time parents spend in preparing the worship activity for their children and the length of the program itself. This was compared with the level of interest shown by the children both during and at the end of their family worship activity.

In this section, parents were requested to list the elements that comprise family worship with their children. It included questions regarding the level of involvement of the children in this activity. The purpose of these questions was to determine the possible connection between the extent of participation and interest of the children. Would their 
direct involvement in family worship, through being given occasional leadership, correlate with the segments of family worship which are most appreciated by children?

This part also aimed to assess the positive effects of family worship in the lives of children. Parents were asked to report their perceptions of such influences in their children's lives, as demonstrated in the attitudes their children show as they relate with other children or other people in different settings. The purpose of these questions about attitude was to ascertain the children's spiritual growth experience as a direct result of family worship. This brought enlightenment about the importance of family worship as an affirmative spiritual activity for children in their homes.

A small section of the questionnaire dealt with the Sabbath School and helped the researcher to link the influence of family worship in preparing children to be more interested and better participants in the Sabbath School program.

Furthermore, in the final section of the second part of the questionnaire, all participants were granted the opportunity to answer some questions that would assist them in evaluating the present condition of their family worship and how they could enhance it in order to make it more relevant and interesting for their families.

These answers provided the researcher with valuable information about how to address the needs and perceptions disclosed in the questionnaire. It also allowed him to capitalize on developing plausible solutions to the identified problems while he prepared the family worship seminar. He took advantage of particular suggestions presented and tried to focus on the areas that could offer participants the necessary information for dealing their own family worship programs. 
A second instrument was used after the final presentation of the "Our Families for God" seminar. It was very specific in its design. It intended to give the participants a chance to appraise the material and the way in which it was presented to them. It included opportunity to offer their own opinions on the positive and negative aspects of the seminar, as well as their general observations.

\section{Methodology}

The researcher used the exploratory method for the preparation of the seminar. He constructed his project and presented answers, based on the information collected through the questionnaire, as well as a review of literature on the subject rather than utilizing "statistical analysis to confirm some claim or assumption made about the data."

The seminar "Our Families for God" was designed to accomplish two goals for the members of the Hamilton Mountain Church. First, it proposed to bring awareness to church members of the importance of family worship. Second, it aimed to improve the practice of family worship among the members, making it a pleasant and significant activity for them, to the extent that it became a tool in their witnessing.

In order to achieve these objectives, "Our Families for God" focused on three main areas. First, it addressed the needs and challenges confronted by members in their experience with family worship. Second, it assisted families who were not practicing family worship to start observing this activity, while the third area dealt with the improvement of this activity, for those who have already been involved with it at home.

'Mario F. Triola, Elementary Statistics, $6^{\text {th }}$ ed. (Reading, MA: Addison-Wesley Publishing Co., 1994), 100. 
The topic of family worship was introduced to the church members through a series of two sermons. The sermons served the dual purpose of introducing the topic of family worship to the church and arousing the interest of the members, so they would participate in the whole project, starting with the questionnaire. These sermons were offered to the church on two consecutive Sabbaths.

The first sermon was presented by the church pastor, who is the researcher, on March 4, 2006. The second sermon was delivered by the Family Ministries director for the Ontario Conference, Mrs. Donna Jackson, on March 11, 2006. The intent of having the sermons preached by two people of different genders was to allow two distinctive approaches. The church pastor deliberated on the general purposes and benefits of family worship for the whole family, but also expanded on the role and responsibility of the father in leading family worship at home. The Family Ministries director presented the message about the importance of family worship from a mother's perspective and experience. She explored the spiritual influence of family worship in the lives of children, too. Both preachers expanded their specific themes, blending with them their own personal experiences with their families and also focusing on how the father and mother can make such an activity interesting and spiritual for their children. This approach allowed the church to obtain the information and motivation about the topic of family worship through two messages that exposed them to the theme from two different angles.

The questionnaire was mailed on March 15,2006to all attending members of the church during the week following the second sermon. Members were requested to answer and return it in the self-addressed stamped envelope provided, within two weeks 
of receiving it. Thus, it offered them the benefit of completing the questionnaire while the motivation created by the two recent sermons was still fresh in their minds.

Families and parents with small children received their survey from the hands of the church pastor, in a previously scheduled pastoral visit, which occurred after the sermons. The intention was to appeal to those families and parents to take part in the questionnaire, because their contribution would be crucial in assisting the researcher in the preparation of a section of the seminar which would address the need for a regular, appropriate, and attractive family worship for children. The self-addressed and stamped envelopes for the parents' responses were not marked and they were exactly the same as those sent to all members. This procedure was intended to preserve the privacy of the families, as well as to give them the freedom to make their comments without the possibility of being identified.

The involvement and participation of the members through the questionnaire was a positive factor in this study. First, it allowed them to freely express their views on the topic and make an evaluation of their family worship experience. Second, it gave them a sense of ownership in this project, as some of their ideas and suggestions were applied. Their responses certainly facilitated the seminar in becoming viable and interesting for church members.

The seminar was developed in PowerPoint format and prepared in four distinctive one hour sections, which included a fifteen minute period for questions and answers at the end of each presentation, except for the first presentation at the eleven o'clock service hour. Those sections introduced the topic of family worship in a creative way and its 
didactics included the why, how, when, and where of family worship. These presentations took place at the church on November 25, 2006.

The seminar was conducted during a specially designated Sabbath that was dedicated to church families. It started in the morning with the Divine Service hour and it continued during the afternoon. The church members were made aware of this event in advance and it was promoted in such a way they that could come and spend the day in fellowship, dedicating those hours to the study of this subject. A potluck lunch was organized for the occasion and a light supper was served at the end of the program.

A second instrument, in the form of an evaluation survey, was given to all participants of the seminar after the presentation of its four sections and of an overall evaluation segment. These forms were deposited by the participants, after the conclusion of the seminar, in a designated box which was specially prepared for this purpose. Detailed precautions were taken to avoid any possible identification of the respondents of this second survey.

This survey intended to allow all participants of the "Our Families for God" seminar to make their personal evaluation and comments regarding the presentations. It also aimed to measure the effectiveness and impact of the seminar in the lives of the church members who participated. The results of this evaluation survey aimed to help the researcher in his conclusions and recommendations. It also acted as an assessment of the seminar.

\section{Analysis of the Survey}

The questionnaire was in quantitative format with sixty questions. This design permitted the respondents to be more specific with their answers, choosing the best 
option that applied to their knowledge, practice, and involvement with the subject of family worship.

The first part of the questionnaire, with thirty questions, included general personal information about the gender, age, and education level of the respondents. They formed the background data to assist the researcher in discovering interesting characteristics of the family worship activity, as seen and practiced by each particular group in the church.

These particulars were relevant in helping the researcher to verify which gender and age groups were more involved and interested in this spiritual activity and also whether educational factors played a significant role in determining a person's participation in family worship. These data were used to ascertain the frequency of family worship, establish the connection between personal devotional time and the practice of family worship, and the elements of family worship.

These general questions about family worship provided the respondents with the occasion to describe the main reasons that conspire against their practice of family worship. They were also invited to reveal their best motivation to practice family worship. The idea behind these questions was to help them weigh the factors that prevent them from regularity in this activity against their best description of what motivates them to conduct the family worship activity. In replying to these questions, they could choose one of the suggested answers or construct their response using their own chosen words. This method provided them with opportunity to be creative and specific in their comments.

The second part of the questionnaire was also comprised of thirty questions that dealt specifically with the topic of family worship with children. Only those who still 
have children living at home were supposed to answer this section. They were asked about the number and ages of the children in their household. This information allowed the researcher to be exposed to the number of members and the ages (especially of the children) represented in each family responding to the survey. It also assisted him to focus on the responses given by each family regarding their perceptions and experiences with family worship, in the context of their own family. In addition, these questions helped the researcher to measure, from the parents' responses, whether the family worship activity for each individual family was appropriate for the children in their respective homes, and be aware of the type of spiritual provision the parents were making for their children.

The question regarding the main figure at home leading family worship was relevant in the light of what Christian literature has to say. The reactions of the children regarding the call for worship at home and their attitude towards it both during family worship time and at its conclusion, were to be compared with the length and components of family worship, as well as the time parents invested in preparing this spiritual activity for their children. The connection between these questions was valuable in discovering if each family's worship was appealing to the children.

The parents' opinions reported in the first part of the survey, as to whether the content or the length of family worship was the most relevant factor, provided the researcher with an indication about the mindset of the parents regarding the topic and the connection between the enjoyment and/or boredom of the children in relation to this activity. The link between the components of family worship that are the most and least appreciated by the children gave evidence about the active involvement and participation 
of the children in the program, including whether they were occasionally allowed by their parents to lead the family worship activity or not.

The general questions concerning the influence of family worship in the lives of the children, aimed to allow the parents to evaluate what they had seen and perceived in the form of attitudes their children displayed towards other people, and especially in their relationship with God as a direct result of what they (children) have spiritually benefited from in their family worship. In this section of questions, the parents were given the chance to indicate their expectations regarding what this spiritual activity might teach their children in the building of their character, as they relate to other people and to God.

The connection between the parents' hopes and whether they (the parents) desired their children to practice family worship with their future families or not, was established to show the weight of importance they (parents) placed in this activity. All of the answers in this portion of the survey allowed the researcher to identify the spiritual expectations of the parents as they conduct family worship with their children.

The segment of the survey that dealt with the influence of the Sabbath School program and its teachers on the children, alluded to the importance of a program that allows for the participation of children. It helped to establish the connection between a participative family worship for the children at home and in the Sabbath School program at church. It also highlighted the significance of a visible spiritual leader for the children, father or mother at home and the Sabbath School teacher at church.

The answer to the question "How did you become a Seventh-day Adventist?" tried to assess the stage of the church members' lives when they came into the church. It also helped to establish the possible correlation between the people who became 
Adventists and had the spiritual support of their families, by either being born into an Adventist home or accepting the message together with their families while they were children or adults, and the proportion of those who practiced family worship. In order to make such a connection, this question was linked with the inquiry in the first part of the questionnaire that asked them how they adopted the practice of family worship. The answers to those questions by this group of people were compared to the replies of those who became part of the church by themselves, but were not encouraged and/or supported in their new faith by their families when they joined the church. This helped the researcher to evaluate the influence of family worship, in comparison with the first group.

The last part of the questionnaire offered the parents the occasion to express themselves in regards to their family worship activities. First, they were asked to make an evaluation of their own family worship and the way they could improve this spiritual activity for their children. They were also requested to state their perceptions concerning their greatest need in order to make family worship attractive and relevant to their families.

Finally, the questionnaire offered the freedom for the church members' personal suggestions in relation to what they would consider to be a successful family worship. Lastly, they were requested to list their expectations in relation to the family worship seminar that would be designed and presented for the church members at a later stage. These last two questions of the questionnaire allowed the researcher to detect the members' level of interest in the topic of family worship, and also in the seminar to follow. 
This questionnaire provided essential information for the researcher to identify the current situation in regards to the practice of family worship in his church, at that point in time. It also assisted him in preparing a seminar that would be appropriate in addressing the needs of his congregation.

The second instrument was actually an evaluation survey that was handed out to all attendees of the seminar. This assessment exercise was conducted at the end of the four sections of the seminar and the debriefing and evaluation period that followed the last segment of the seminar. Each participant was requested to answer this form individually.

The evaluation survey had general and specific questions regarding the seminar. First, participants were asked to indicate their gender and age, which allowed the researcher to measure the efficiency of the seminar by gender and age. Then, specific questions were presented in the format of short statements related to the seminar. They had to indicate their opinion by choosing whether they agreed or disagreed with ten statements that evaluated the seminar in specific areas. Those statements were about the organization and structure of the seminar; the clarity of the language used in the seminar; relevancy of the subject; content and length of the seminar, as well as its practicality as a whole; whether it introduced new ideas about family worship, and if so, the practicality of those ideas; whether the seminar was interesting for the children and challenging for the parents or not. They were asked to evaluate these areas of the seminar by a simple Yes or No answer to the statements. These statements tried to verify the standard of the information the participants received and also their interest in the seminar itself. 
The evaluation of the seminar was also measured by the participants' responses to the open-ended questions related to the benefits they gained from the seminar or areas they felt that it failed to address, as well as their overall remarks about the seminar. These questions provided them with the opportunity to make their personal observations about the seminar in which they had participated.

The evaluation survey assisted the researcher in preparing his conclusions about the effectiveness of the seminar. It also exposed him to the most important areas that needed to be considered and given special attention in preparation for dynamic and relevant family worships. All of these allowed him to make specific recommendations on the topic. 


\section{CHAPTER IV}

\section{HAMILTON MOUNTAIN CHURCH FAMILY WORSHIP FINDINGS}

\section{Introduction}

This chapter presents the results of the family worship questionnaire completed by the members of the Hamilton Mountain Seventh-day Adventist Church as part of the implementation process of the Family Worship Seminar. It describes the procedure for making the questionnaire available to the church members as well as divulging the findings, along with comments related to each part.

\section{Procedure}

A total of 301 questionnaires were mailed to the church members on March 15, 2006. This only happened after the preaching of two sermons on the topic of family worship, by Pastor Wesley Torres who is also the researcher, and Mrs. Donna Jackson, Ontario Conference Family Ministries Director on March 4 and 11 respectively. The children's story segment of the Divine Service on Sabbath March 18 was about the benefits of family worship for children and it intentionally served as a reminder to church members about the questionnaire. Parents of young children received their questionnaires directly from the researcher during previously scheduled pastoral visits. These procedures were also outlined and thoroughly explained in the methodology section of this project. 
Every questionnaire had a cover letter explaining the project itself to members and requesting their participation by answering the attached instrument. The cover letter also stated that the results and findings of the questionnaire would assist the researcher in the preparation of a family worship seminar to be presented to the church at a later stage. Each questionnaire contained a self-addressed stamped envelope, assuring the participants that their answers would be treated as private and confidential. Samples of the questionnaire and letter are shown in the appendices.

Church members were requested to answer and return the questionnaire by March 31. The rationale behind the date was to induce them to answer the questions while all the motivation and inspiration of the recent sermons were still fresh in their minds. The researcher, who is the church pastor, reminded them verbally about it from the pulpit for the following two Sabbaths (March 18 and 25). This reminder was also printed in the church bulletin.

Many members mailed their questionnaires back within the time frame, but the researcher decided to extend the deadline for four more weeks (April 25), and this was announced in church and printed in the church bulletin. This decision made it possible for more people to participate in this study.

\section{Results}

The researcher received 182 questionnaires, which represented 60.46 percent of the questionnaires distributed to church members. This percentage met the researcher's expectation of receiving at least 60 percent of the distributed questionnaires in order to have a figure that would represent a reliable picture of the practice of family worship in the church. 
According to the answers given by the respondents in the questionnaire, the demographic information regarding the gender, age, and educational levels is shown in table 5 below.

Table 5

DEMOGRAPHIC COMPOSITION OF THE SAMPLE

\begin{tabular}{lrl}
\hline $\begin{array}{l}\text { Demographic } \\
\text { Questions }\end{array}$ & $\mathrm{N}$ & $\begin{array}{l}\text { Response } \\
\text { Percentage }\end{array}$ \\
\hline Gender & & \\
Male & 65 & 35.7 \\
Female & 102 & 56.0 \\
Not identified & 15 & 8.3 \\
& 182 & 100 \\
Totals & & \\
& & \\
Age & 9 & 4.9 \\
12-16 & 12 & 6.6 \\
$17-20$ & 30 & 16.5 \\
$21-30$ & 32 & 17.6 \\
$31-45$ & 33 & 18.1 \\
$46-60$ & 66 & 36.3 \\
Over 65 & & \\
& 182 & 100 \\
Totals & & \\
& 5 & 2.7 \\
Education & 17 & 9.4 \\
Primary incomplete & 27 & 14.8 \\
Primary complete & 42 & 47.3 \\
Secondary incomplete & 86 & 2.7 \\
Secondary complete & 5 & 100 \\
College or higher & 182 & \\
Not identified & & \\
Totals & & \\
& &
\end{tabular}


Question 4 in the questionnaire asked whether the individual had ever practiced family worship or not. Only those who answered "yes" to this question were supposed to continue to answer the remainder of the questionnaire. If the respondent answered "no," the person was requested to stop answering the questionnaire right there and mail it back to the researcher. Their participation was still encouraged, as they were instructed to return the questionnaire with their answers up to that question.

The rationale for this procedure was based on the fact that people needed to have had some sort of experience with the practice of family worship in order to be able to provide adequate answers to the subsequent questions of the questionnaire, as it would deal specifically with this family spiritual activity. Table 6 shows the results of this question.

Table 6

PRACTICE OF FAMILY WORSHIP

\begin{tabular}{lll}
\hline \hline Have Practiced & $\mathrm{N}$ & Percentage \\
\hline Yes & 139 & 76.4 \\
Gender & & \\
$\quad$ Male & 41 & 29.5 \\
$\quad$ Female & 83 & 59.7 \\
$\quad$ Not identified & 15 & 10.8 \\
Totals & 139 & 100 \\
No & 43 & 23.6 \\
Gender & & \\
$\quad$ Male & 24 & 55.8 \\
Female & 19 & 44.2 \\
Totals & 43 & 100 \\
\hline
\end{tabular}


A group of 139 people who answered "yes," revealing that they have practiced family worship at one or more stages in their lives, represented 76.4 percent of the initial number of 182 responses. This provided a reasonable percentage to continue the study. It also gave the researcher assurance that the responses of those people could provide him with a positive contribution to this study.

Out of the 139 people who have practiced family worship, 109 of them, (78.4\%) being 66 females, 31 males, and 12 people with no gender identification, are presently practicing this spiritual activity. Twenty-nine are not currently having family worship $(20.9 \%)$, while 1 person $(0.7 \%)$ did not answer the question.

The educational levels of those who are presently practicing family worship, as compared to the literacy levels of all the initial 182 respondents, were as follows: 5 out of 5 respondents $(100 \%)$ with primary education incomplete; 13 out of 17 people $(76 \%)$ with primary education complete; 20 out of 27 people (74\%) with secondary education incomplete; 28 out of 42 people (67\%) had a complete secondary education; 68 out of 86 people $(79 \%)$ with college education or higher; while all 5 people $(100 \%)$ who did not indicate their education level are practicing family worship. 


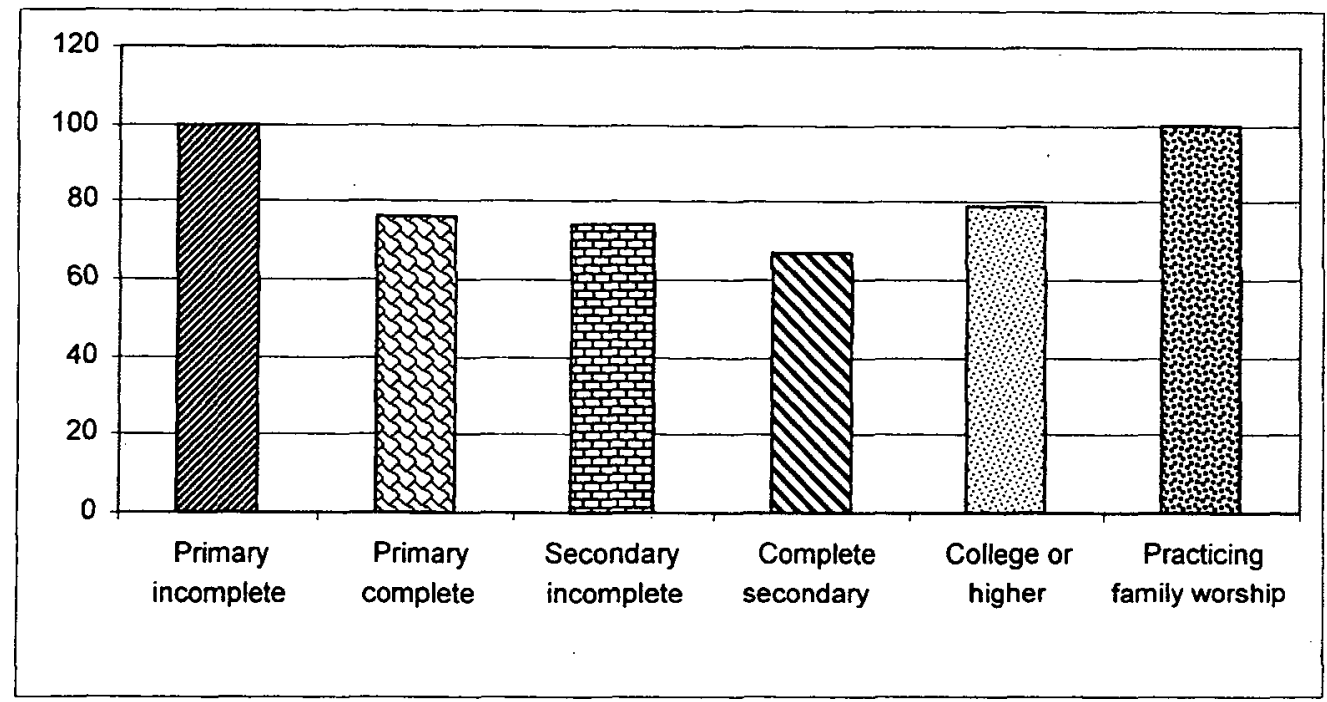

Figure 1: Formal education levels of the 139 respondents.

This showed that those with an incomplete primary education are more involved with the practice of family worship than the people in the other formal education levels. It also revealed that there is a balanced distribution among the other groups that ranked $76 \%$ with primary education complete; $74 \%$ with secondary education incomplete; $67 \%$ with secondary education complete, and $79 \%$ with college or higher levels.

The frequency of family worship for those 139 people who have practiced this spiritual activity revealed that $37.5 \%$ practiced it daily; $21 \%$ frequently; $37.5 \%$ occasionally and the remaining $4 \%$ answered either rarely or did not answer this question.

One of the amazing discoveries was related to the way members adopted family worship. This discovery is presented in table 7 below, which shows all of the answers provided by the 139 respondents, except for 2 people who did not answer this question. It also includes a combination of more than one answer by 13 of the respondents. 
Table 7

\section{ADOPTION OF FAMILY WORSHIP}

\begin{tabular}{|c|c|c|c|}
\hline Questions & $\mathrm{N}$ & Percentage & Total N \\
\hline Grew up practicing $F W$ & 82 & 59.0 & \\
\hline Adopted FW after marriage & & & \\
\hline $\begin{array}{l}\text { or birth of a child } \\
\text { Influenced by friends or }\end{array}$ & 30 & 21.6 & \\
\hline church family & 16 & 11.5 & \\
\hline Influenced by FW messages & 22 & 15.8 & \\
\hline Other & - & - & $150^{*}$ \\
\hline
\end{tabular}

This is a clear message for all Christian homes, especially parents, revealing that the influence of a home that practices family worship will impact their children positively to continue observing this spiritual activity in the future.

Also, $55 \%$ of the 139 respondents declared that they have a specific time for their family worship activity, while $45 \%$ indicated that they do not. When the comparison is done with those who are presently practicing family worship, $61.5 \%$ have a set time while $38.5 \%$ do not. The most common time for family worship is in the evening (48.62\%), followed by morning (21.10\%), and morning and evening (18.36\%). Those who have family worship only on weekends amount to $6.42 \%$ while $5.5 \%$ of those who answered the questionnaire did not respond this question. 

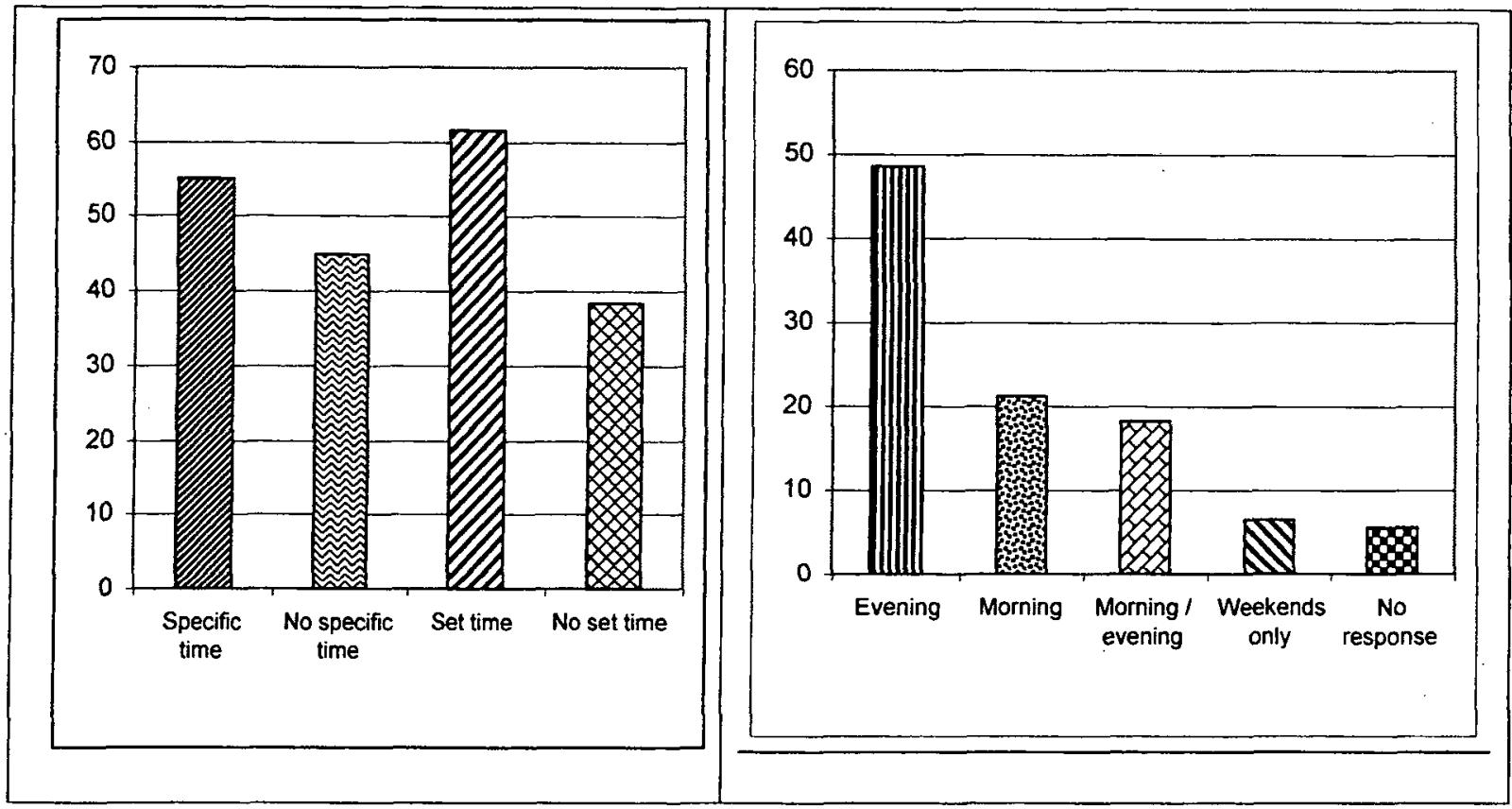

Figure 2: Set time for family worship and most common time for family worship.

Another remarkable discovery was that $84.89 \%$ of those who have ever practiced family worship also had a personal devotion time besides their family spiritual activity. The percentage among those who are presently practicing family worship is $83.49 \%$. This certainly confirms that there is a close connection between the practice of personal devotion and family worship which is confirmed in the available Christian literature dealing with the subject. 


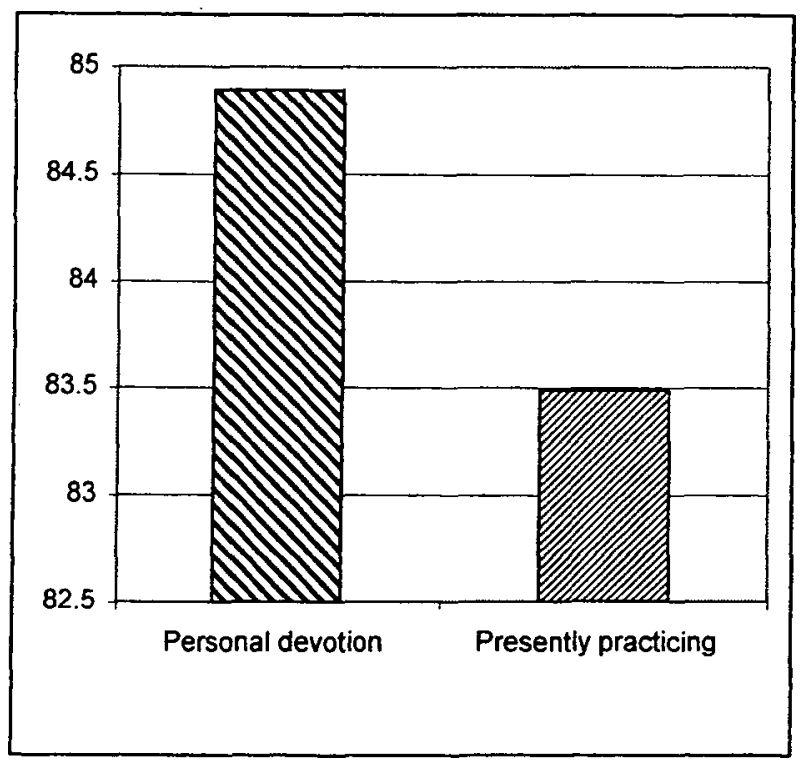

Figure 3: Family worship and personal devotion.

The questionnaire also revealed that the living room was the most common place for families to gather for their family worship (64.03\%) followed by the parents' bedroom $(15.11 \%)$, and dinner table $(13.67 \%)$. This tendency is repeated by those who are presently practicing family worship.

Regarding the parts that comprise family worship, church members indicated that prayer (91.37\%); Bible reading (79.41\%); songs (63.31\%) and the Sabbath School lesson study $(59.71 \%)$ were the top elements. The percentage of those whose family worship also included the reading of the morning devotional, bedtime stories, and the use of multimedia resources, ranked at $38.13 \%, 21.58 \%$, and $17.99 \%$ respectively. This shows that members are practicing the basic elements of family worship in their homes. 


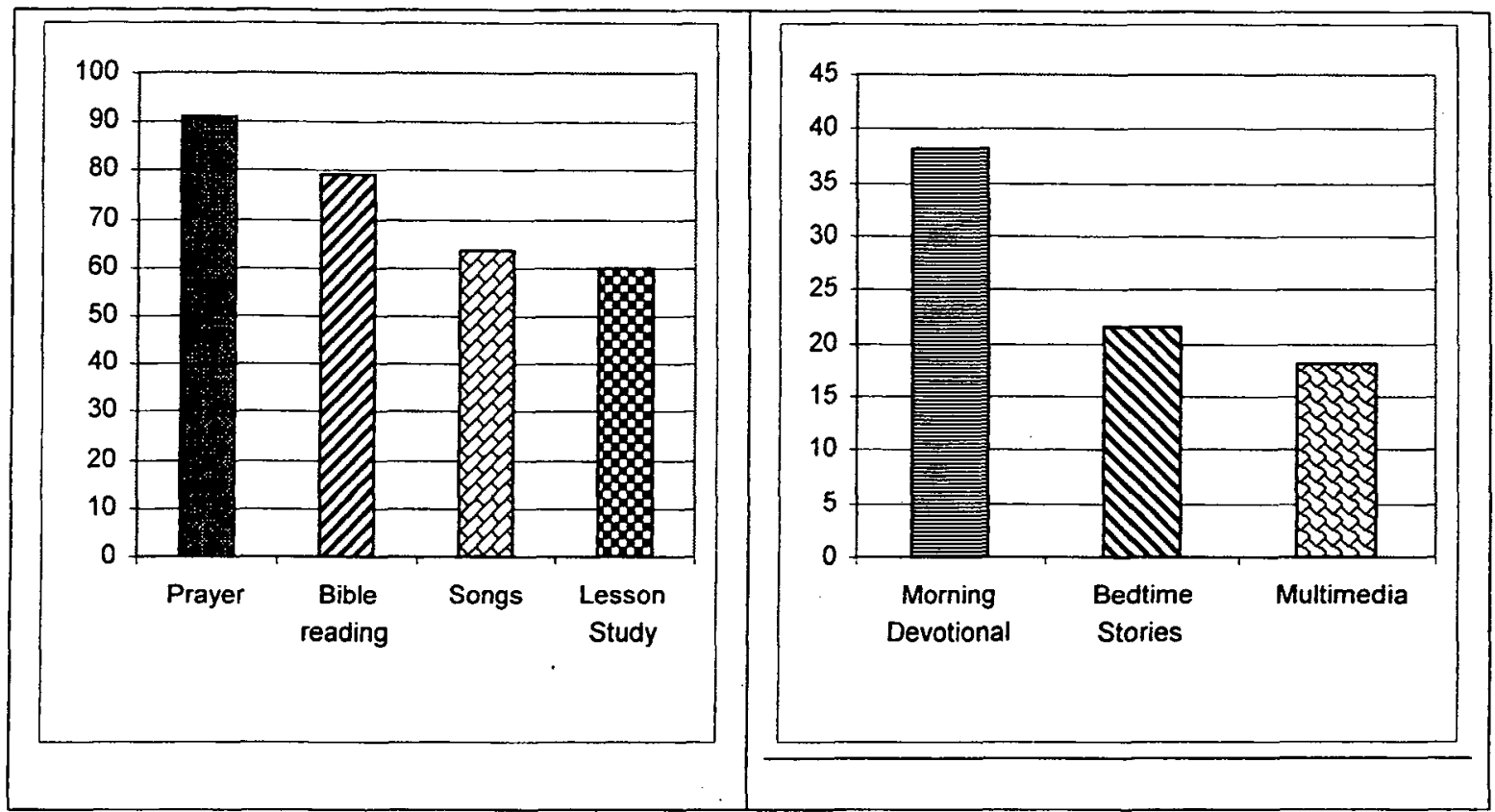

Figure 4: Elements of family worship and resources used for family worship.

The largest group among the 139 participants in the questionnaire (40.29\%) evaluated their family worship as good. Those who considered it as average equaled $32.37 \%$, while $7.19 \%$ believed it was outstanding. The other percentages were below average $(7.19 \%)$, poor $(5.76 \%)$, very poor $(2.88 \%)$ or did not answer this question (4.32\%). Considering those who are presently practicing family worship (109), the trend was repeated except that the evaluation for good rose to $44.96 \%$, average $33.03 \%$, and outstanding to $9.17 \%$. An impressive finding was that the rate for below average was $6.42 \%$, poor $4.59 \%$, and those who did not answer this question represented $1.83 \%$, while no one judged their family worship as very poor. This shows that they are happy about the way they are conducting their family worship, but there is also room for improvement to make it outstanding and raise the level of satisfaction for the other groups. 


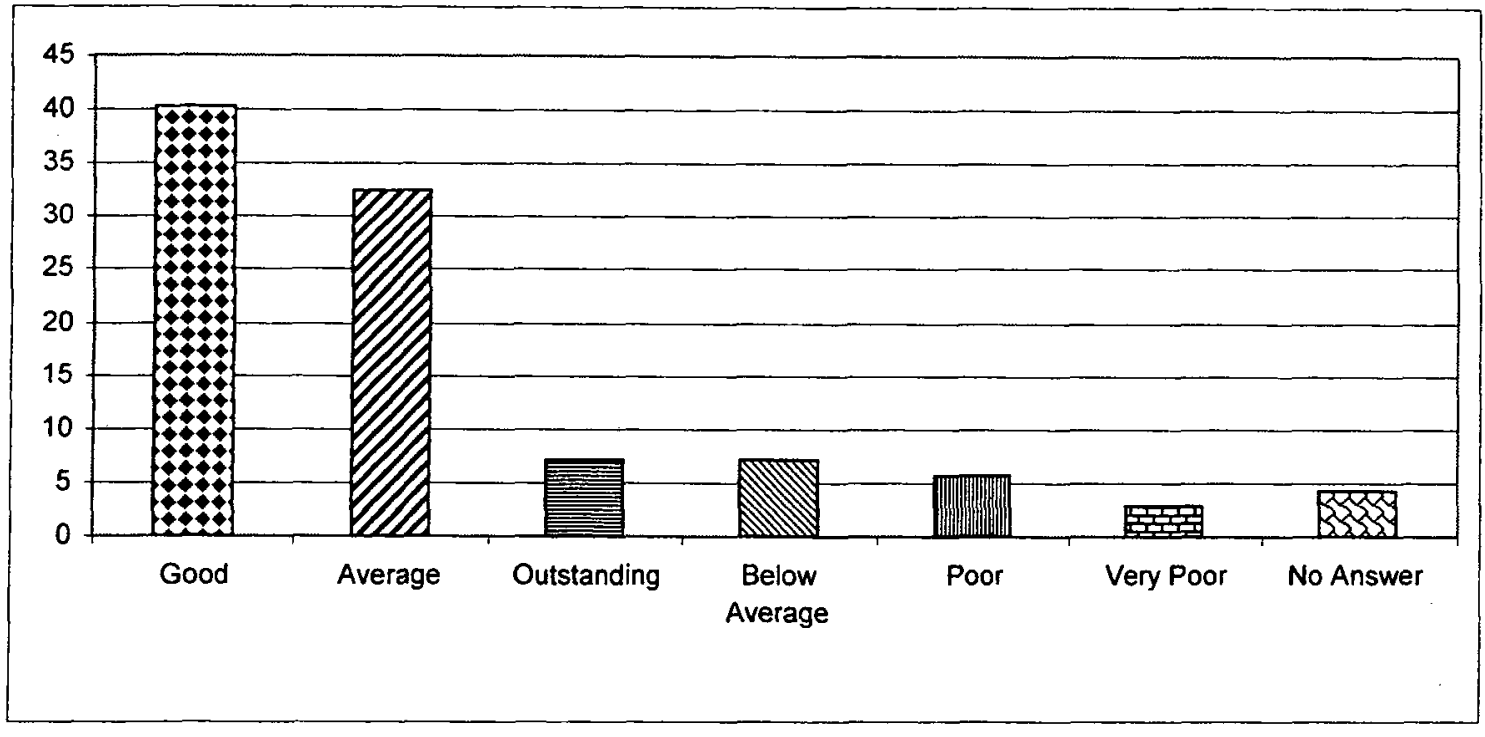

Figure 5: Members' personal evaluation of their family worship.

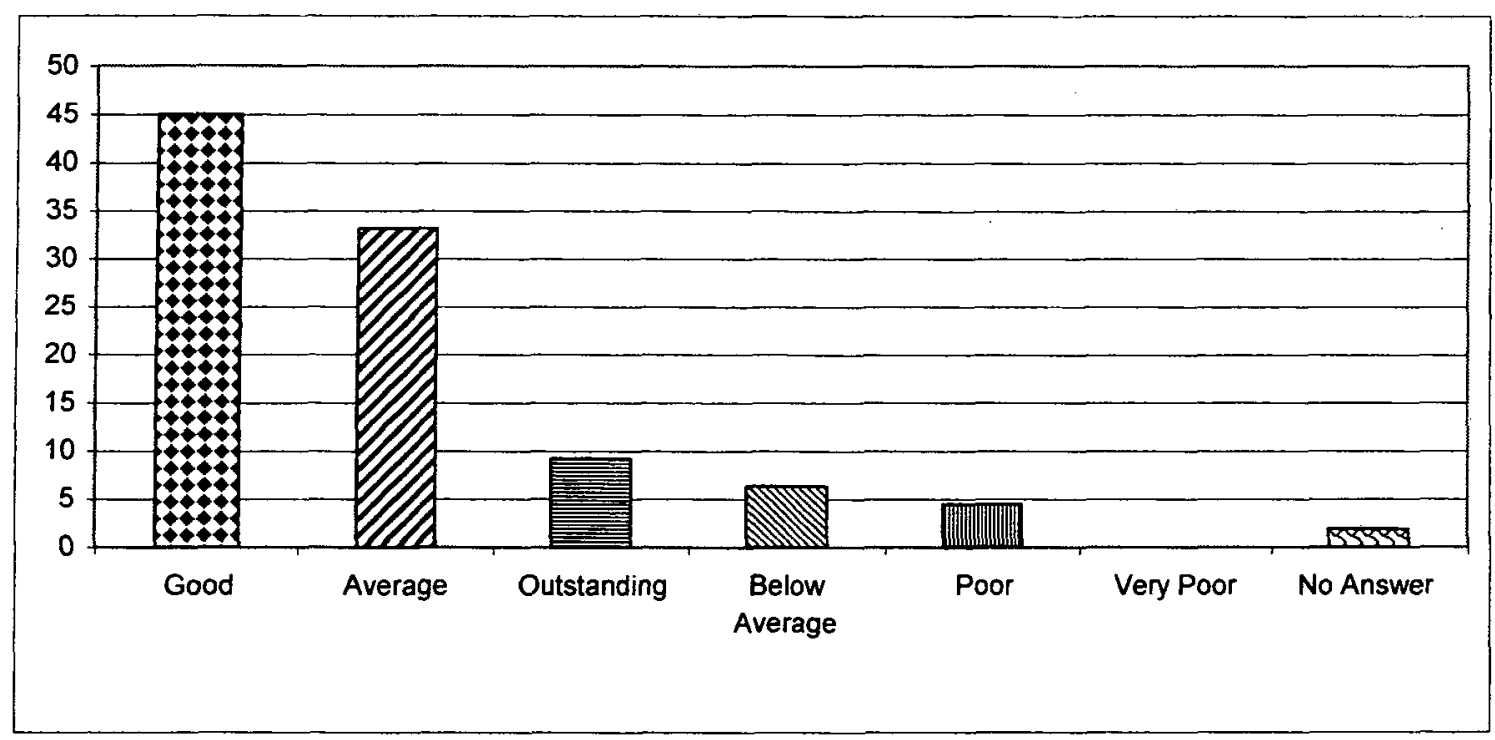

Figure 6: Members' personal evaluation—-presently practicing family worship.

The responses relating to the reasons which sometimes affect the practice of family worship revealed no surprises, as the main ones were lack of time and planning, tiredness, and work-related commitments. Considering that very few pointed out a 
specific time, either in the morning or evening for their family worship, it shows that although this activity is taking place in their homes, it suffers the consequences of a busy lifestyle and different schedules faced by people in their work.

Members could choose more than one answer to express their perceptions about how to enhance their family worship. The answers showed that $54.68 \%$ of them admitted that they needed to improve their time management and $49.64 \%$ agreed that they should pray for more spiritual interest. Some indicated that they need to study more about the subject (14.39\%); seek counsel from friends (7.91\%); feel it is acceptable the way it is (6.47\%); and others (4.32\%). Those who did not answer this question rated $38.85 \%$ and it could be an indication that they are happy the way they are conducting this activity.

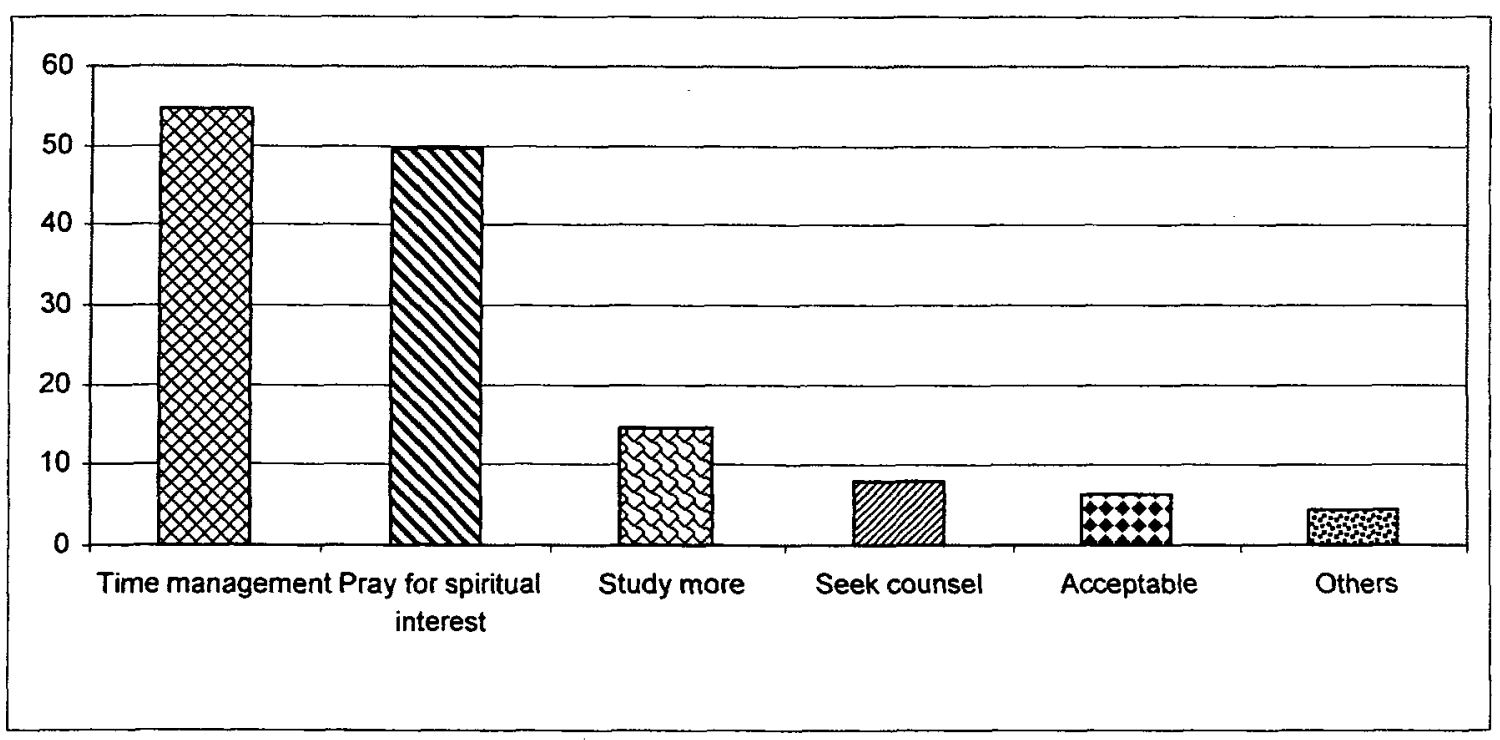

Figure 7: Members' perceptions about how to improve their family worship. 
Prayer was considered the most important part of family worship by $91.36 \%$ of the 139 respondents, followed by Bible reading with $84.89 \%$; songs $62.58 \%$; Sabbath School lesson study $56.83 \%$; morning devotional reading $48.20 \%$; bedtime stories $35.97 \%$; and multimedia resources $33.09 \%$. These statistics exposed a close correlation between the way the members answered this question (16) and question 12 . They evaluated the order of importance of the parts of family worship, in the exact sequence in which it was practiced. It is interesting to note that $20.86 \%$ declared that all of these elements are important.

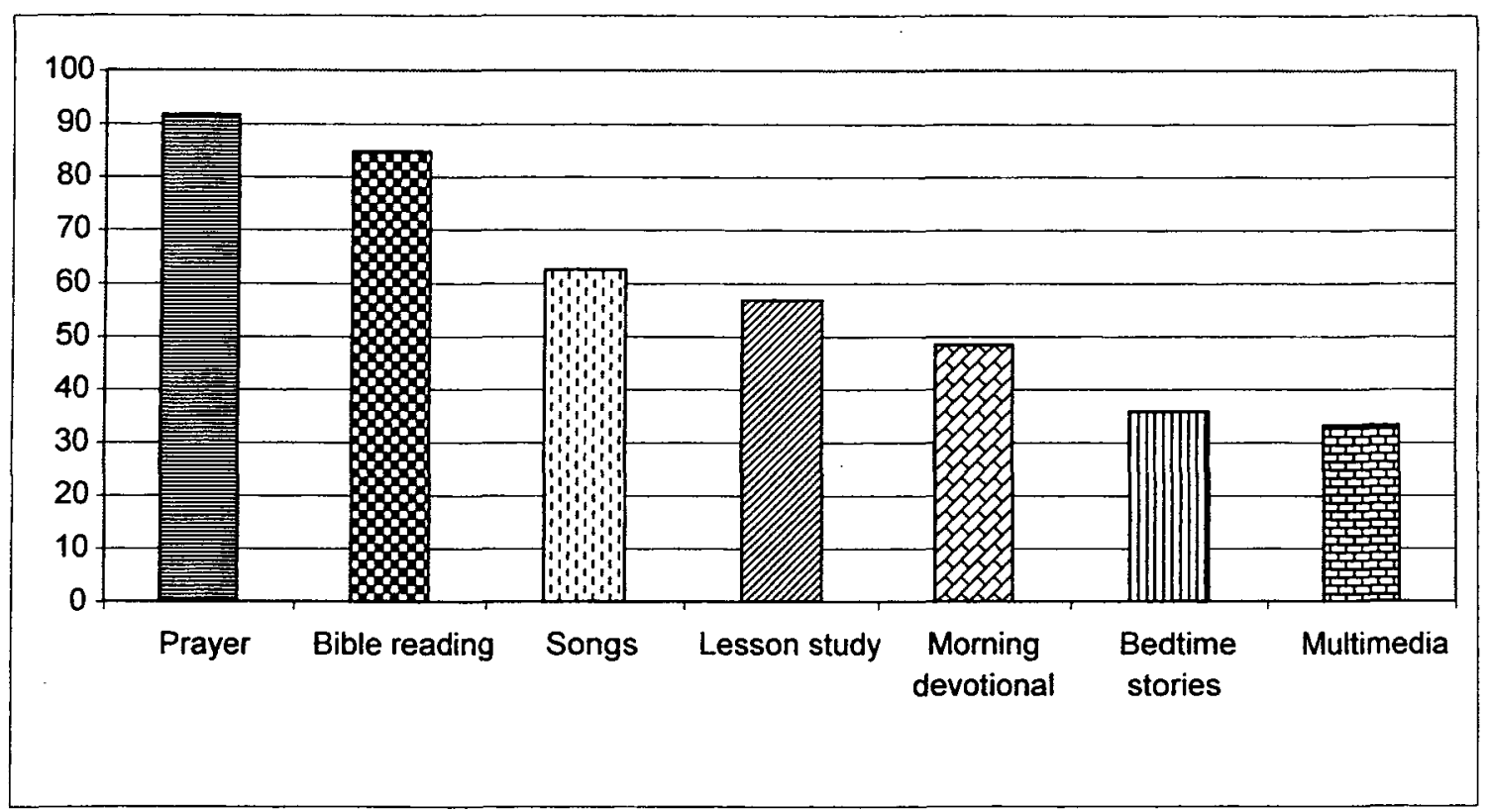

Figure 8: Most important elements of family worship as judged by members. 
The questionnaire asked the participants to indicate the average time of their family worship. The answers revealed that most of the church members' family worship times averaged 20 minutes (42.44\%), while there was a close ratio among the other options. Those with a family worship of 10 minutes represented $19.42 \%$; up to 30 minutes $16.55 \%$; more than 30 minutes $17.27 \%$; and $4.32 \%$ did not answer this question.

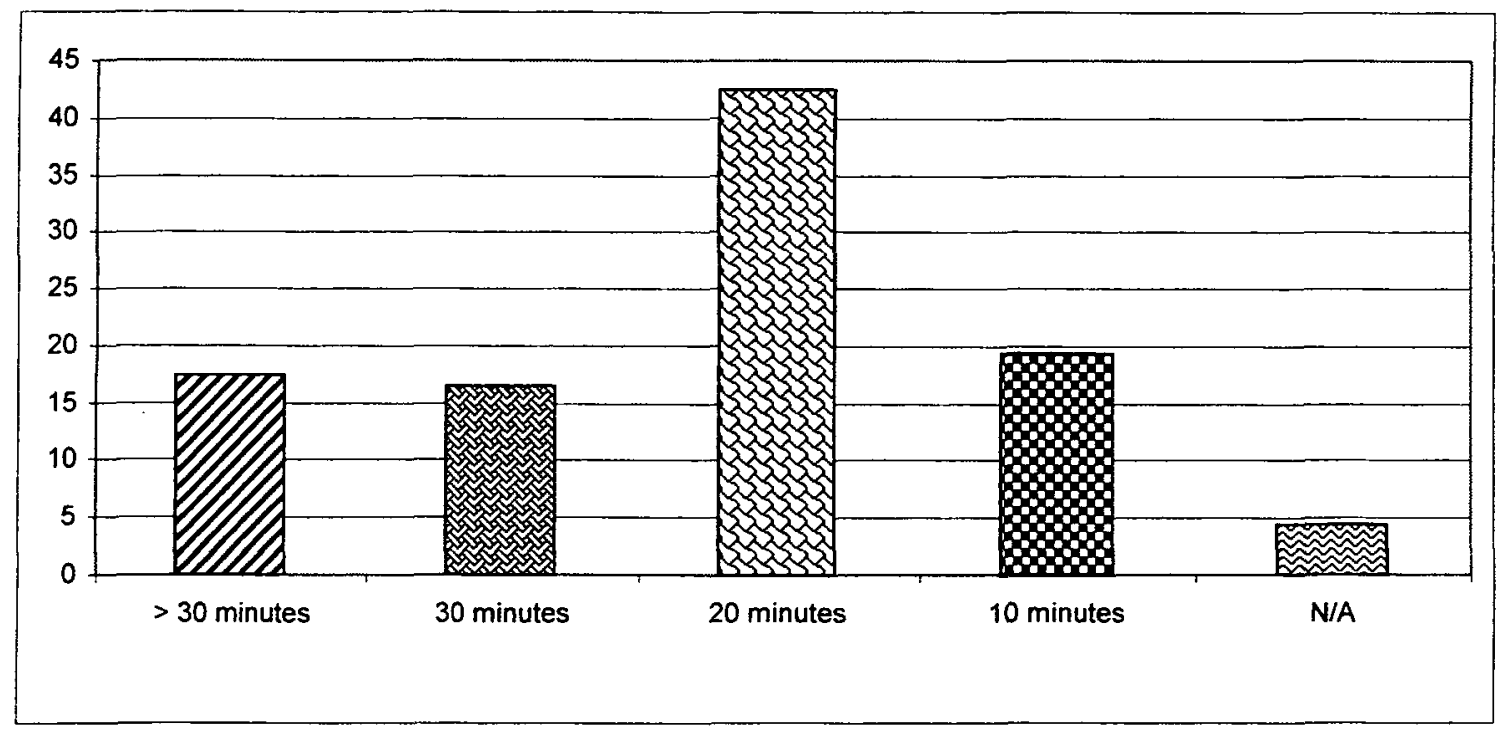

Figure 9: Members' family worship average length percentage (\%). 

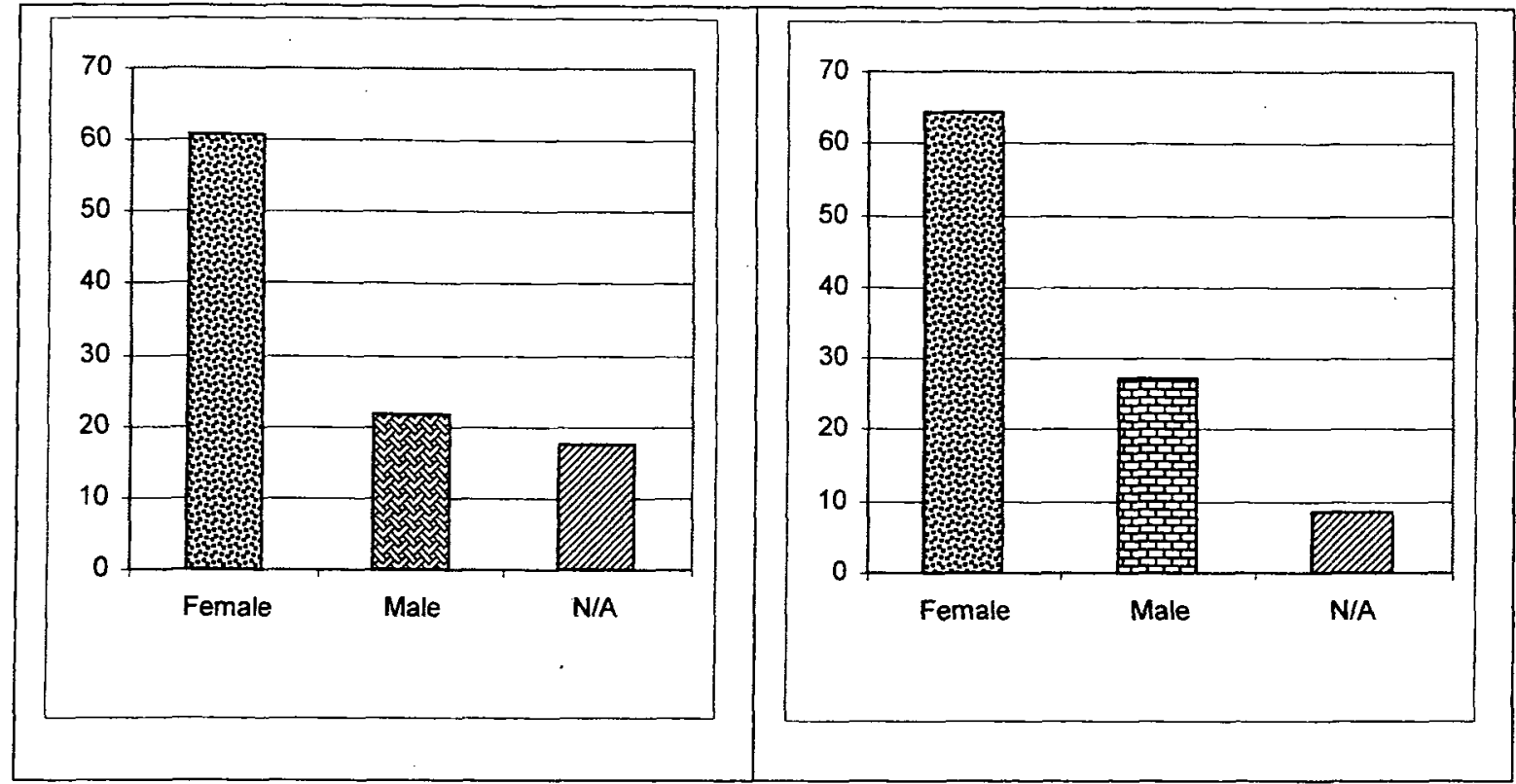

Figure 10: Gender comparison-30 minute length and 20 minute length family worship percentage (\%).

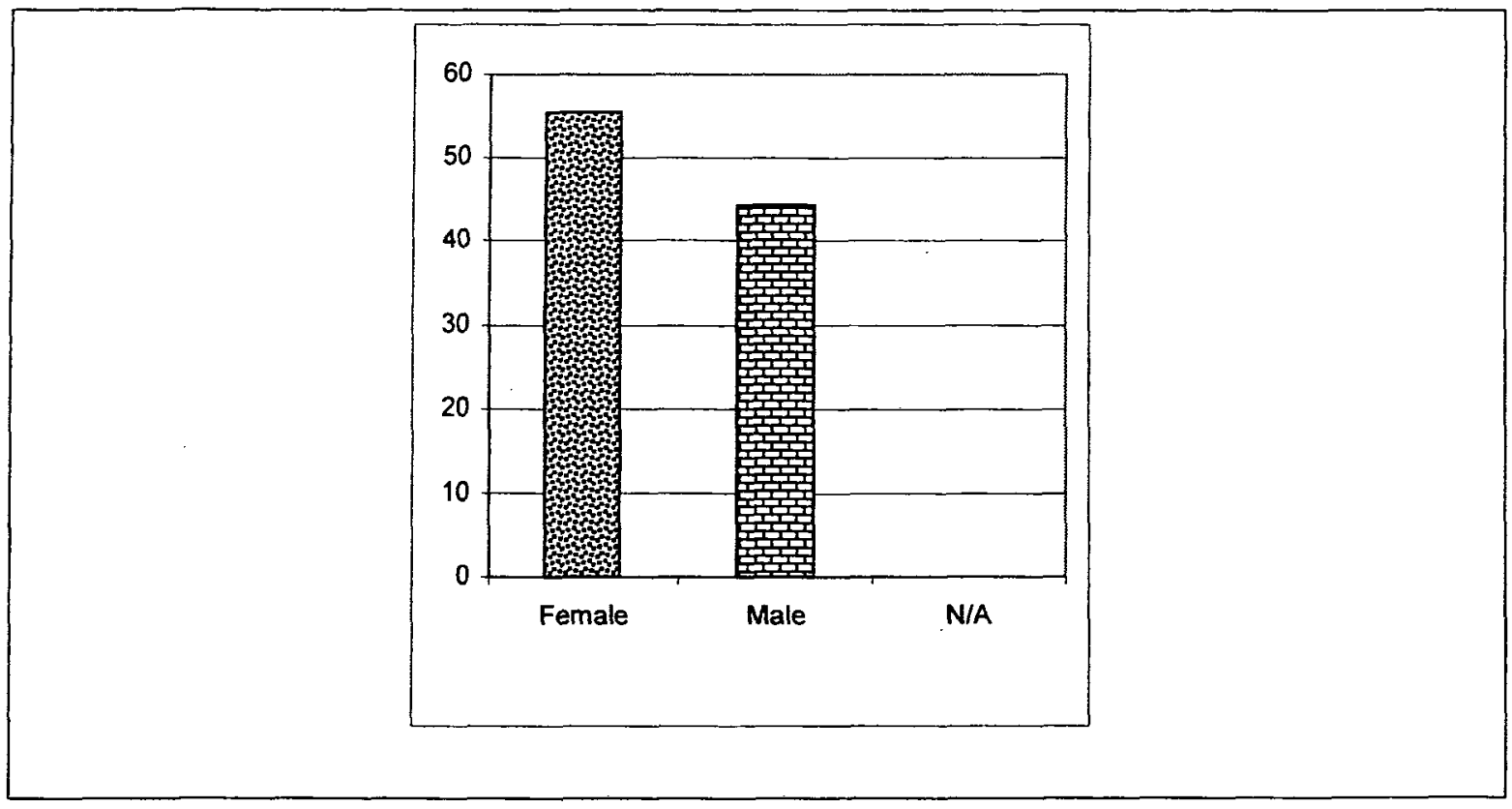

Figure 11: Gender comparison—10 minute length family worship percentage (\%). 
Worth noting was the fact that the female gender seemed to spend more time with their family worship as compared to males. The graphics below illustrate this reality.

After these findings a question needs to be posed. Are these numbers indicators that the female gender is more interested in the time element of family worship than the males, or that males are more concerned with the length of family worship than the females? In order to clarify these discoveries, members were asked about what was most relevant for the family worship experience. Members were given the options of length, content, or both, in order to answer this question. The results were as follows:

Table 8

MOST RELEVANT FACTOR OF FAMILY WORSHIP

\begin{tabular}{lrc}
\hline \hline Question & $\mathrm{N}$ & Percentage \\
\hline & & \\
Length & 4 & 2.88 \\
Contents & 67 & 48.20 \\
Both & 58 & 41.72 \\
Other (No answer) & 10 & 7.20 \\
Totals & 139 & 100 \\
& & \\
\hline
\end{tabular}


Table 9

GENDER VS. LENGTH AND CONTENTS FACTORS OF FAMILY WORSHIP

Question

Length

Male

Female

Totals

Contents

Male

Female

Not Identified

Totals

Both

Male

Female

Not Identified

Totals

Other (No answer)
$\mathrm{N}$

$\begin{array}{ll}3 & 75 \% \\ 1 & 25 \%\end{array}$

4

100

38.81

53.73

7.46

100

15.51

72.41

12.08

$\begin{array}{ll}72 & 12.08\end{array}$

58

100

The findings regarding the outlook of the genders in relation to length and contents of family worship were definitive.

This is surely an indication that males place more value on the time (length) than the content. It was not the purpose of this study to discover the reasons behind this fact, although the results were very clear.

An interesting discovery was that $42.44 \%$ of the members saw the mother as the one who takes the initiative for family worship, while $27.34 \%$ appointed the father as the 
leader. The answers also revealed that $17.27 \%$ of the people assigned both, father and mother on the same level and $12.95 \%$ of them did not answer this question. This showed that mothers are taking the leading role in conducting this family spiritual activity at home.

This finding contradicts the legacy of the Jewish tradition and also the counsels of the Ellen G. White, who assigns such responsibility to the father as the 'priest of his household.' It also sends a clear message to those fathers who have not been the spiritual leaders of their homes as they should, at least as it refers to initiating family worship.

People chose more than one option to indicate their best motivation to practice family worship. Members were more interested in their spiritual communion with God than in their accountability before God, in relation to family worship in the home. The practice of family worship was associated with the desire for family and/or personal communion with God for $61.87 \%$ and $55.39 \%$ of the members respectively. Those who opted for personal and/or their children's accountability before God, rated $34.53 \%$ and $21.58 \%$ in that order. Tradition, habit, or routine scored $10.07 \%$ only.

These responses correlated well with those of question 15, in which people expressed their desire to improve the level and frequency of their family worship. $54.68 \%$ responded that they needed to enhance their time management, while $49.64 \%$ believed they should pray further for spiritual interest, as already mentioned.

Questions 21 to 30 inquired about the possible connection between some of the Seventh-day Adventist fundamental beliefs, as they relate to the practice of family worship, and the benefits sensed by members from their own experiences with family worship. More than $90 \%$ of those who evaluated their worship as outstanding, good, or 
at an average level, answered positively about their beliefs, such as having Jesus real in their lives, a solid belief in the second coming of Christ, the Sabbath day; pardon of sins through the blood of Christ; a positive attitude towards prayer, respect and reverence for the Word of God; assurance of God's blessings, and their daily spiritual growth with God. They associated their family worship observance as being vital in affirming their faith in those doctrines, in bringing unity between family members, and in promoting a religious heritage in their family.

It was interesting to discover that those $10 \%$ who were uncertain whether their family worship was furthering their beliefs and/or sponsoring unity and their religious legacy, assessed their worship as below average, poor, or very poor.

\section{Family Worship with Children}

The second part of the questionnaire dealt with family worship with children and thirty-nine people, whether parents, grandparents, or legal guardians answered this section.

The number of children in the household was reported as one by $30.77 \%$; two $48.72 \%$; three $17.95 \%$, and more than three by $2.56 \%$. This shows the tendency for two or less children in the members' households.

The attitude of the children in relation to family worship time was measured by their reaction to the call for worship. The answers were very positive. 
Table 10

DEMOGRAPHIC COMPOSITION OF PARENTS

\begin{tabular}{lrrll}
\hline \hline Question & $\mathrm{N}$ & Percentage & Total N & Total Percentage \\
\hline Gender & & & & \\
$\quad$ Male & 9 & 23.08 & & \\
$\quad$ Female & 25 & 64.10 & & \\
$\quad$ Not identified & 5 & 12.82 & 39 & 100 \\
$\quad$ & & & & \\
Ages & 3 & 7.69 & & \\
21 to 30 & 17 & 43.59 & & \\
31 to 45 & 13 & 33.33 & & \\
46 to 60 & 1 & 2.56 & & 100 \\
$\quad$ Over 61 & 5 & 12.83 & 39 & \\
$\quad$ Not identified & & & & \\
\hline
\end{tabular}

Table 11

CHLDREN'S ATTITUDE TO THE CALL FOR FAMILY WORSHIP

\begin{tabular}{lrccc}
\hline Question & $\mathrm{N}$ & Percentage & Total N & Total Percentage \\
\hline & 16 & 41.02 & & \\
Come at the first call & 16 & 43.59 & & \\
Come at the second call & 17 & 5.13 & & \\
Show indifference & 2 & - & & \\
Pretend not to hear & - & 5.13 & 39 & 100 \\
Need to be brought & 2 & 5.13 & 39 & \\
Did not answer & 2 & & & \\
& & &
\end{tabular}

One of the remarkable findings in this section was that 30 people $(76.92 \%)$ reported that their children exuded an attitude of enjoyment during family worship. Only 7 people $(17.95 \%)$ stated that their children displayed some sort of indifference, while $5.13 \%$ did not answer this question. These numbers confirm that the children are happy about the way their family worship is being conducted. 
It also was revealing to compare the answers of those thirty people who confirmed an attitude of enjoyment experienced by their children during family worship, in the second part of the questionnaire, with the length of their family worship as mentioned in the first part of the instrument. The results are displayed in table 12 below.

Table 12

CHILDREN'S ENJOYMENT VS. LENGTH OF FAMILY WORSHIP

\begin{tabular}{lrlll}
\hline Question & $\mathrm{N}$ & Percentage & Total N & Total Percentage \\
\hline Enjoyment with FW & & & & \\
10 minutes length & 5 & 16.66 & & \\
20 minutes length & 14 & 46.67 & & \\
30 minutes length & 8 & 26.67 & & \\
More than 30 min. length & 3 & 10.00 & 30 & 100 \\
& & & & \\
\hline
\end{tabular}

This showed a close relationship between the length of the worship and level of enjoyment experienced by the children. Also, family worships lasting 30 minutes or more amounted to $42.86 \%$ of those who showed indifference during their family's spiritual activities.

Another amazing finding was the connection made by the report, which indicated the enjoyment of the children during their family worship relates to the relevancy factor of the content and length of family worship. The link established by the answers on the questionnaire proved interesting. 
Table 13

CHILDREN'S ENJOYMENT VS. CONTENT AND LENGTH FACTORS

\begin{tabular}{lrrrr}
\hline \hline Question & $\mathrm{N}$ & Percentage & Total N & Total Percentage \\
\hline Enjoyment & & & & \\
$\quad$ Length & 1 & 3.33 & & \\
Content & 18 & 60.00 & & \\
Both & 10 & 33.33 & & \\
Other (No answer) & 1 & 3.33 & 30 & 100 \\
& & & & \\
\hline
\end{tabular}

This attested to the fact that the parents are balancing well the content and length of their family worship, and the time allocated for this family spiritual activity is appropriate.

Regarding the children's response at the end of their family worship, $61.53 \%$ the respondents considered that their worship time was just right, while $12.82 \%$ said that their children usually ask them to continue worship time. This shows that the majority of children were also happy and interested by the end of their family worship. The connection was established between those who showed enjoyment during family worship and their responses at the end of this activity. The finding was interesting as it revealed that the children held positive feelings about their family worship.

The questionnaire revealed that a fair percentage of the parents $(41.02 \%)$ are spending some time weekly preparing for their family worship time with their children, while $48.72 \%$ declared that they did not spend any time in preparation. Some of the members $(10.26 \%)$ did not answer the question related to the time spent in family worship preparation. 
Table 14

FAMILY WORSHIP WEEKLY PREPARATION TIME

\begin{tabular}{lrcrl}
\hline \hline Question & N & Percentage & Total N & Total Percentage \\
\hline Up to 30 minutes & 15 & 38.46 & & \\
Up to 1 hour & 1 & 2.56 & & \\
Up to 2 hours & - & - & & \\
More than 2 hours & - & - & & \\
None & 19 & 48.72 & 39 & 100 \\
Did not answer & 4 & 10.26 & 39 & \\
\hline
\end{tabular}

Nonetheless, $93.75 \%$ of those who spent time in preparation for their family worship also reported that their children showed enjoyment during their family worship. Furthermore, $86.66 \%$ indicated that their children's response at the end of their family worship time was either asking for the worship to continue or that it was just right for them.

In contrast, only $52.63 \%$ of those who reported no preparation time for their family worship said that their children asked for the continuation of their family worship or that their worship time was just right. This discovery highlighted the importance of investing some time in preparing a family worship program for children, and it also revealed that the Hamilton Mountain church members still have some improvements to make in this area.

The questionnaire disclosed that more than three-fourths of the parents have allowed their children to take an active part during their family worship. In the homes where children are actively involved in family worship, an overwhelming rate of $93.33 \%$ of those children have showed an attitude of enjoyment during their worship experience. 
Also, $90 \%$ of those children either asked that the activity continue or felt that its length was just right for them.

In addition, $50 \%$ of the parents who somehow actively involved their children in family worship also spent some time preparing the activity. Conversely, none of the children of those parents who did not spend time preparing for family worship was involved in their family worship activity. These remarkable findings are exhibited in the tables below.

Table 15

CHILDREN'S INVOLVEMENT IN FAMILY WORSHIP

\begin{tabular}{lrrrr}
\hline \hline Question & N & Percentage & Total N & Total Percentage \\
\hline Children are active in FW & & & & \\
Yes & 30 & 76.92 & & \\
No & 6 & 15.38 & & \\
Did not answer & 3 & 7.70 & 39 & 100 \\
& & & & \\
\hline
\end{tabular}


Table 16

ACTIVE \& INACTIVE CHILDREN VS. FAMILY WORSHIP ENJOYMENT

\begin{tabular}{lrrr}
\hline \hline Question & $\mathrm{N}$ & Percentage & Total \\
\hline \multicolumn{2}{l}{ Children show enjoyment in FW } & & \\
Active & 28 & & \\
Inactive & 1 & 93.33 & $(30)$ \\
& & 16.66 & $(6)$ \\
Children show indifference in FW & & \\
& & & $(30)$ \\
Active & 2 & 6.66 & $(6)$ \\
Inactive & 5 & 83.33 & \\
\hline
\end{tabular}

Table 17

FAMILY WORSHIP PREPARATION TIME VS. CHILDREN'S INVOLVEMENT

\begin{tabular}{lccc}
\hline \hline Question & $\mathrm{N}$ & Percentage & Total \\
\hline Parents' preparation (time) for FW & & \\
Children involvement in FW & & \\
Yes & 15 & 50.00 & $(30)$ \\
No & 6 & - & $(6)$ \\
\end{tabular}

The contrast was striking for those children who did not take an active part in their family worship. Only $16.67 \%$ showed enjoyment and $83.33 \%$ exhibited indifference during their family spiritual activity. None of those parents who did not assign any active role to their children in their family worship invested time in preparing this activity. Again, only $16.67 \%$ of their children felt that their worship time was just 
right as $83.33 \%$ of the children were tired or the parents were uncertain about their children's response at the end of their family worship.

Parents reported that songs were the most appreciated part of their family worship, followed by stories and prayer, while Bible reading and the morning devotional reading were the least appreciated. This finding reveals that children do not welcome readings during their family worship.

It was reported that the part of the family worship program that the children were most involved with is prayer, followed by asking questions and being engaged with their Sabbath School lesson.

The questionnaire also revealed that $64.10 \%$ of the parents have permitted their children to lead out in their family worship time, and of those who have done this, $48 \%$ of parents spent some time preparing for their family worship. The level of enjoyment experienced during family worship rated at $84 \%$ among the children who have been given the opportunity to lead out during family worship and $80 \%$ of them had a positive response at the end of their family worship.

In contrast, $63.64 \%$ of those parents who have not allowed their children to lead out in family worship have spent no time in preparing for the family worship, while $72.72 \%$ of their children enjoyed the program and had a positive response at the end of the family worship.

An overwhelming majority of parents reported their belief that family worship has a positive influence in the lives of their children. This answer was linked with the attitude of enjoyment during family worship and the responses of the children after this spiritual activity. The findings did not present any surprises. Those children whose 
parents had spent some time making preparations for their family worship, and had allowed them to lead out in this spiritual activity at home, scored much higher in all the areas mentioned above. These facts only confirmed that when parents invest time in preparing their family worship program for their children and allow them to take an active part and/or lead out in the activity, these factors contribute positively towards better appreciation by the children and their active participation in family worship.

Parents indicated that teaching the importance of communion with God and teaching obedience and reverence were the family worship activities that would create the most positive influence in the lives of their children. They also revealed that the development of a love for God and obedience towards both God and their parents, were the most highly regarded aspects of the influence and teachings of family worship. Their responses show that they aim for high spiritual goals when conducting their family worship.

A significant majority of parents reported a perception of positive influences resulting from family worship, in the lives of their children. These were mainly observed through the children's relationship with their parents, friends, neighbors, and other children. These influences were noted mostly through the children's attitudes of respect and kindness. The attitudes of forgiveness, unselfishness, and generosity scored high, too. These discoveries showed that family worship can play a major role in modeling Christian values, teachings, and expectations in the lives of the children.

Parents strongly expressed their belief that family worship develops a spiritual awareness which allows their children to develop a better perception of God. They also wished their children to practice family worship with their future families. In addition, 
$87.50 \%$ of the parents declared that the practice of family worship in their parental families had influenced them to practice family worship with their children. This answer correlates perfectly with the findings of the questionnaire about how people adopted family worship. Again, it demonstrates the undeniable impression caused by a home (family) that practices family worship. Its influence is positive and long lasting.

Most of the parents believe that the Sabbath School program and lesson are closely related-they prepare their children for family worship at home, which in turn assists their children to be participative in the Sabbath School program. The percentage of those who so believed, but also invested time in preparation for their family worship and allowed their children to be active and/or lead out in their spiritual activity, was much higher than those who did not follow this pattern.

The questionnaire revealed that parents firmly believe the Sabbath School teachers contribute to the spiritual growth of their children. It showed the relationship between the leaders and teachers of the Sabbath School, and the main figure leading them in their family worship at home. This revealed that children associate the person in charge of their family worship at home with the spiritual activities at church. The link between the responses relating to how people adopted family worship and the way they became members of the church, reconfirmed that families that practiced family worship exercised a great deal of influence in those parents to continue with this practice in their own homes.

It was delightful to put these figures together. The results of the questionnaire have shown that the members of the Hamilton Mountain church not only value the practice of family worship; they also take this activity very seriously. However, there 
still remains the challenge to motivate a considerable percentage of members to make family worship a customary activity in their homes, as well as to encourage nearly one quarter of the congregation to adopt this practice with their families. The results were both very positive and challenging at the same time.

These findings were used during the preparation and presentation of the family worship seminar "Our Families for God." They also inspired the researcher to use the observations and conclusions to develop recommendations for the members of the Hamilton Mountain Seventh-day Adventist Church. 


\section{CHAPTER V \\ “OUR FAMILIES FOR GOD" SEMINAR}

\section{Introduction}

This chapter unfolds the preparation and development of the family worship seminar which was entitled "Our Families for God." The main goal of the seminar was to highlight the importance of this spiritual activity in the lives of those who profess the Christian faith. It especially targeted improvement in the practice of family worship in the homes of the members of the Hamilton Mountain Seventh-day Adventist Church.

\section{Development of the Seminar}

The seminar was planned utilizing the information found in available Christian literature. Practical perspectives on the topic were also collected by the researcher who used his own interest and practice of family worship. Suggestions were also received from the church members through the means of a questionnaire. This procedure expanded the researcher's views and perceptions on the topic as he was exposed to the needs and expectations of the members in relation to family worship.

The writings of Ellen G. White were another very important source of information. She wrote extensively on the subject and her views and counsels on the topic are highly regarded by the members of the Hamilton Mountain church. Through his 
visitation with church members, the researcher was able to verify their acceptance of her inspiration and also their respect for her writings. As a result of these factors, an entire section on Ellen G. White's comments and counsels on the topic of family worship was included in the theological chapter of the dissertation. A number of references to her instructions were also included during the presentation of the seminar.

During the construction of the seminar, consideration was given to the presentation of the topic in a motivational way so that the holistic concept of family worship would be accepted. Special consideration was given to those parents who still have children living at home. The seminar was intended to assist them in making family worship an attractive and practical spiritual activity for their children.

In order to achieve such a goal, the seminar was introduced and presented in different segments. The sections included: the characteristics of family worship, the role of parents-especially the father-in leading family worship at home, the elements and dynamics of family worship, how to make family worship a potential evangelistic tool, and practical help for parents preparing materials for their family worship. The seminar was also developed with the idea of assisting members to make their family worship not only a blessing in their own homes, but also to help them share the spiritual benefits gained with others with whom they are closely associated.

The final stage of the organizational process of the seminar considered the length and the number of segments in the seminar. Since it was designed for the purpose of instructing and motivating the members of the Hamilton Mountain church to adopt the practice of family worship or to enhance their current practices in this area, the seminar was introduced on a specific and well-promoted Family Sabbath day at the church. The 
church members were notified well in advance and invited to participate in this program specifically designed for church families.

\section{Description of the Seminar}

The family worship seminar "Our Families for God" was organized in four informative sessions. They were:

1. The Biblical Foundations for Family Worship

2. The Elements and Characteristics of Family Worship

3. The Benefits of Family Worship

4. The Family Worship Program with Children.

The researcher intended that the seminar would be informative and especially very practical for the church members. He endeavored to use simple and clear language during the presentations and used home-made materials in his illustrations, which could also be prepared by the participants, especially by parents in their homes. The seminar presentation was in PowerPoint format.

In order to make the seminar presentation interesting and practical, the participants received a set of 'Seminar Work Sheets' to fill in during the different sessions. At the end, the printed format of the seminar was made available to all who wished to take it home. This technique allowed the members to participate more efficiently during the presentation of the seminar, maintaining their interest and focus. This method also encouraged involvement so they were not merely spectators, but had some notes ready for the discussion period. 


\section{The First Session-The "Why" of Family Worship}

The first session involved a presentation on the theological and biblical foundation for family worship. It highlighted the importance of this spiritual activity from a theological perspective as it relates to the development of faith, especially for Christians. It cited examples of Bible characters as they ordered and gathered their household members around their family altar and conducted combined worship of God. It also presented the reasons why God's children ought to worship Him. Through this section the researcher established the 'Why' of family worship.

\section{The Second Session-The "How" of Family Worship}

The second segment presented the basic characteristics of Christian family worship. It revealed what makes family worship a distinctive activity for Christian believers and also detailed the elements that comprise this spiritual activity. Another purpose of the second session was to present the different segments of family worship and introduce suggestions as to how to make them practical and relevant for each family member.

Relying on Bible models and Ellen G. White's writings, suggestions were offered that related to the elements and characteristics of family worship. Here again, practical examples of how to creatively arrange each part of a family worship program in order to make it attractive and captivating for all family members, were used. In this context of practicality, the second section of the seminar explored and expanded the 'How' of family worship. 
The Third Session-The Benefits of Family Worship

The aim of the third session was to present and discuss the benefits that are closely associated with the practice of family worship. This part of the seminar underscored the natural God-given human need for a family as a supporting group that should share mutual values, objectives, and feelings. Then, it expanded on the perceived blessings that this spiritual activity brings to the family members as it enhances their ties of unity, respect, love, and support both among themselves and with God.

\section{The Fourth Session-Family Worship with Children (The When \& Where)}

The fourth segment dealt specifically with family worship programs incorporating children. It endeavored to offer parents specific suggestions related to planning and conducting an appropriate and inspiring family worship. In his presentation, the researcher concentrated his efforts on introducing new ideas and methods, which included some materials that could help keep the children involved and interested in this spiritual activity. This session combined the 'Why' and 'How' previously discussed, and also included the 'When' of family worship, in an earnest attempt to reach the minds of the children. A plan was developed and introduced for the 'Where' of family worship, especially when it involves children.

\section{Dialoguing with the Participants}

During the presentation of the seminar, the researcher instructed the participants to note their queries or comments and save them for a debriefing period at the end of each section. Then, they were invited to express their personal opinions regarding the topic. 
The purpose of this approach was to promote an orderly dialogue between the members and the researcher, through the format of a question and answer period.

One of the strategies for making this seminar relevant to those who attended it was to encourage good communication between the researcher and the participants. This methodology aimed to instill in the members a strategy which they could emulate for the exchange of ideas in their own family circles, as they prepare and conduct their family worship. Feedback from the participants regarding their perceptions was a valuable asset for the researcher, both during the planning and introduction of the seminar.

The Implementation of the Seminar

The implementation of the seminar "Our Families for God" started several months before its actual presentation to the members of the Hamilton Mountain church. The topic of family worship was brought to the church members through a series of two sermons that were preached at the church on March 04 and 11, 2006. The intent of having these two sermons on the topic was to kindle the interest of the members in the subject. On March 18, 2006 the children's story segment of the Divine Service also emphasized the benefits of family worship. This was conducted in an appropriate language for the children and served to remind all members about the family worship questionnaire that they were kindly requested to answer.

During the week following the preaching of the second sermon, 301 carefullyworded questionnaires about family worship practices were mailed to those members who fitted on the category of active members of the church. 


\section{Schedule of the Implementation Phase}

1. March 4, 2006-First sermon on the topic of family worship by Pr. Wesley Torres, Hamilton Mountain church pastor, researcher.

2. March 11, 2006-Second sermon on the topic of family worship by Mrs. Donna Jackson, Family Ministries Director for the Ontario Conference.

3. March 15, 2006-301 questionnaires about family worship were mailed out to church members. The suggested return date for the questionnaire was by March 31, 2006.

4. March 18,2006-Children's story at the Divine Service hour was about the benefits of family worship.

5. March 18, 25, 2006-Announcements in the church bulletin and verbal reminders from the pulpit to church members to return the questionnaire by March 31, 2006.

6. April 1, 8, 15 and 22, 2006-Announcements in the church bulletin and verbal reminders from the pulpit to church members to return the questionnaire by April 25, a new extended date.

7. April 28, 2006-Last survey received and included in the tabulation of the questionnaire.

8. May through October 2006-Evaluation, research, and tabulation of the questionnaire as well as the preparation and development of the seminar.

9. November 25, 2006-Presentation of "Our Families for God" seminar at the Hamilton Mountain church. This day was set aside from months in advance as a 'Family Sabbath Day.' The church was well represented on that occasion and the members were 
excited about the main topic to be presented and discussed on that specific day of worship.

The presentations by the researcher, who is the church pastor, started during the divine worship hour and continued in the afternoon. A potluck lunch was organized for the church family that Sabbath to facilitate the presence of the church members and a smooth flow into the seminar in the afternoon.

10. December 2006 through February 2007-Evaluation, research, and conclusions about the final evaluation of the seminar elicited from church members at the end of the seminar presentation at church.

\section{Length and Contents of the Seminar}

The seminar "Our Families for God" consisted of four sessions of one hour each, which included fifteen minutes for questions and answers, except for the first session. The sessions and their contents were presented in the following order:

$1^{\text {st }}$ Session: "The Why of Family Worship"-a theological and Biblical reason for the worship of God at home.

$2^{\text {nd }}$ Session: "The How of Family Worship"-Elements and characteristics of a spiritual activity that brings a family together.

$3^{\text {rd }}$ Session: "The Family Altar"- The benefits of a spiritual activity that brings a family closer to God.

$4^{\text {th }}$ Session: "Worshipping God with Children at Home"-Uniting the why, how when, and where of worshipping God at home. 


\section{Schedule of the Sessions of the Seminar}

The seminar was presented to the Hamilton Mountain church on November 25, 2006. The schedule of the sessions of the seminar was as follows:

$1^{\text {st }}$ Seminar Session: at the 11:00 o'clock Divine Service.

$2^{\text {nd }}$ Seminar Session: from 2:45-3:30 P.M., followed by 15 minutes for questions and answers and a 5 minute break.

$3^{\text {rd }}$ Seminar Session: from 3:50-4:35 P.M., followed by 15 minutes for questions and answers and a 5 minute break.

$4^{\text {th }}$ Seminar Session: 4:55-5:40 P.M., followed by 15 minutes for questions and answers and a 20 minute break.

The Evaluation of the Seminar

The evaluation of the seminar took place on the same day, November 25, 2006 after the presentation of the four interactive sessions. The evaluation period commenced at 6:15 P.M. and it was intended to promote an overall discussion of the whole seminar. Thirty minutes were allowed for this segment. During this time, members were invited to present their opinions, offer their positive or negative feedback about the seminar itself, and also make use of all of their notes collected during the seminar sessions. Each participant received a pack containing worksheets for each session of the seminar, along with a little notepad. These tools proved to be very effective for this discussion and evaluation exercise.

At the end of the evaluation period all church members were asked to fill in an evaluation form about the seminar. The participants were requested to place their 
evaluation forms in a specifically prepared box. This method ensured no trace of identification of the participants/respondents.

After all evaluation forms had been received, a prayer of consecration was offered by the researcher, on behalf of all participants of the seminar and their families. This prayer asked the Lord to bless them richly as they erect a family altar in their homes. It also aimed to strengthen their commitment to the establishment or extension of family worship practices.

At the conclusion of the program, a light supper was served at the church for all participants of the "Our Families for God" seminar. The results are presented below.

\section{Results of the Final Evaluation Survey}

The researcher received 179 evaluation surveys after the closing of the seminar. This number represented 59.47 percent of the number of people who initially fitted into the category of active members of the church (301), as discussed in chapter three, and 98.35 percent of the 182 people who answered the questionnaire about family worship. The researcher was satisfied with the response received, considering that his initial goal was to have 60 percent of the members of his church involved in this project. According to his opinion, this percentage of people could provide valid data on the perceptions and interest of the Hamilton Mountain church members on the topic of family worship.

Conversely, these 179 evaluation forms collected after the seminar represented an increase of forty people (28.77\%) when considering that out of the 182 people who initially answered the family worship questionnaire, only 139 had ever been involved with this spiritual activity before. This clearly shows the level of awareness about family 
worship had been raised in church members as a result of the processes and methodology used by the researcher. It also resulted in an increased rate of participation during the presentation of the seminar.

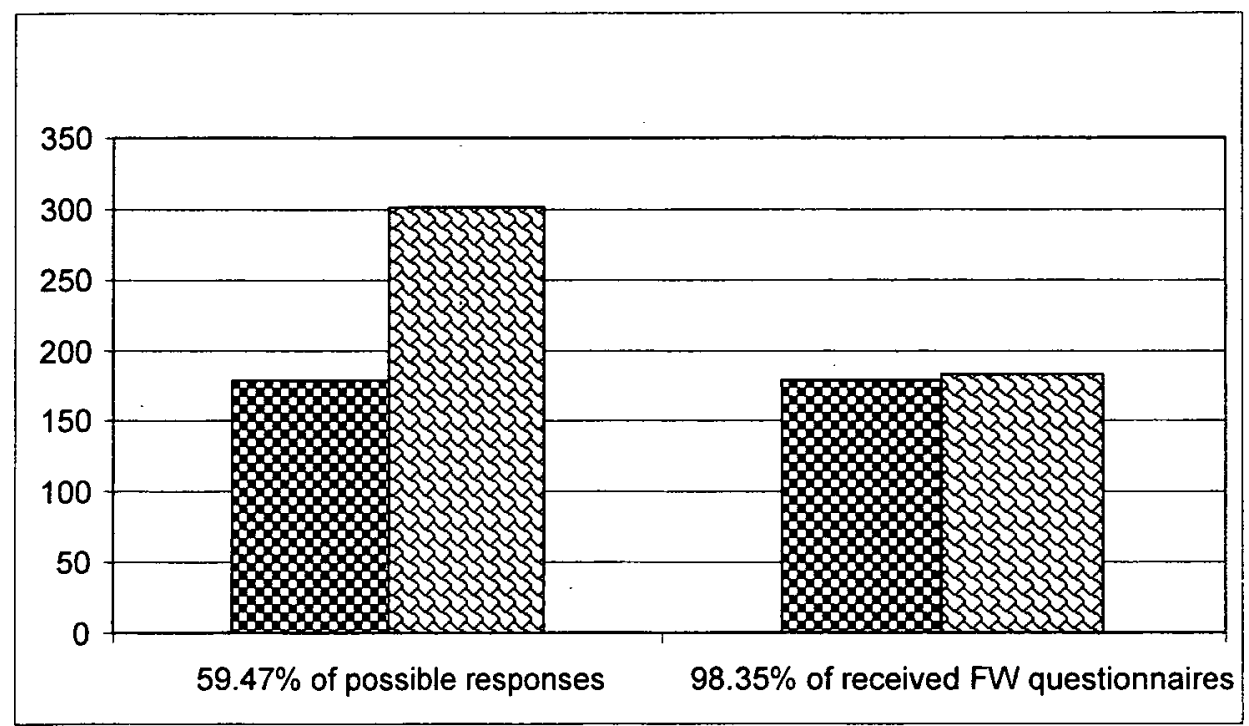

Figure 12: Members' participation and evaluation of the family worship seminar.

Overall, the researcher was pleased with the results of the final evaluation. They are presented in detail below.

The gender composition of the 179 respondents was represented by 111 females (62.01\%) and 68 males (37.99\%). Their age groups were as follows: 12 people with the age of up to 20 years (6.70\%); 36 aged between 21 and 30 years (20.11\%); 48 aged between 31 and 45 years (26.82\%); 34 whose age ranged from 46 to 60 years $(18.99 \%)$; and 49 people in the age group of more than 61 years $(27.38 \%)$. 


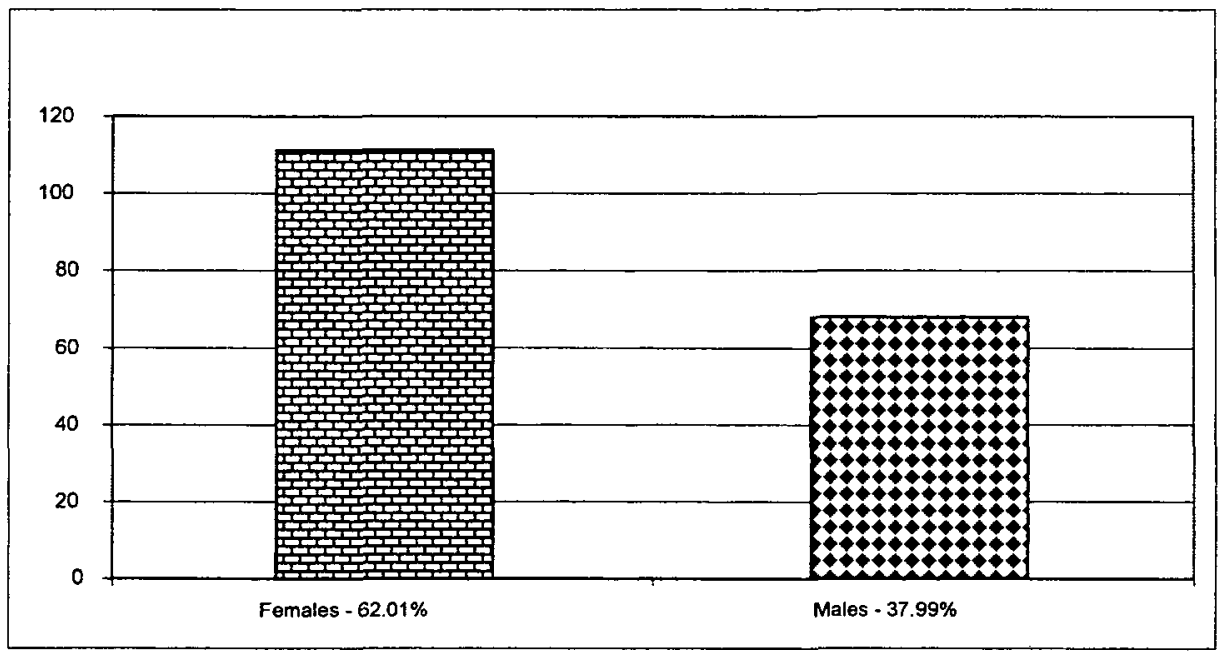

Figure 13: Gender representation in the evaluation of the family worship seminar.

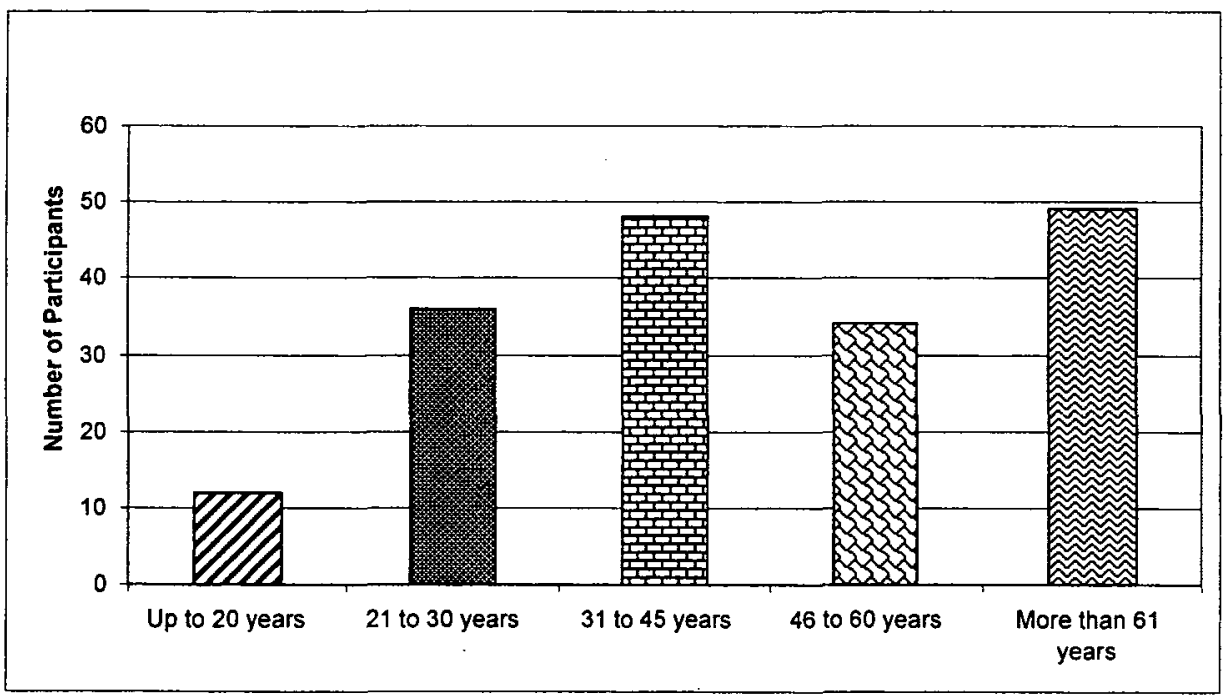

Figure 14: Age of the participants in the evaluation of the family worship seminar.

The rate of satisfaction with the organization and structure of the seminar reached 100 percent. All 179 respondents seemed to have appreciated the way the researcher organized and structured the seminar in his presentations. Only 2 people declared that 
the language used during the presentation of the seminar was not clear $(1.12 \%)$, and those responses came from the people aged up to 20 years. Conversely, this represented 16.66 percent of the responses from that age group, which could be an indication that there were some concerns with the clarity of the vocabulary used by the researcher in his presentation.

One hundred seventy-eight respondents agreed on the relevancy of the material presented and that its contents were helpful. The only negative responses to those questions came from one person in the up to 20 years age group, who had also not agreed about the clarity of the language. This could indicate that that specific person was not really grasping and/or appreciating the family worship concepts as they were being presented by the researcher.

The area that challenged people the most on the negative side of the seminar was in relation to its length. Although 79.89 percent perceived the length to be appropriate, 35 people (19.55\%) responded that the length was not suitable or it was too long, while one person $(0.56 \%)$ did not answer this question.

The researcher realized that the time factor or length as related to the presentation of the seminar could present a problem. Several of those 35 people mentioned that the seminar would have been more effective for them if it were split over two or even three days, instead of being conducted all on just one day. The researcher received a clear indication about the way the members felt in regards to the length of the seminar, although the format implemented, after consultation with his advisor, seemed to be the most feasible and effective method to assist the researcher in obtaining the most evaluation forms back. The approach of an extensive day seminar would make available 
to him the full expression of the members' assessment of the seminar. However, the matter of the length of the seminar will be considered seriously by the researcher in his plans to present the seminar to other people or churches in the future.

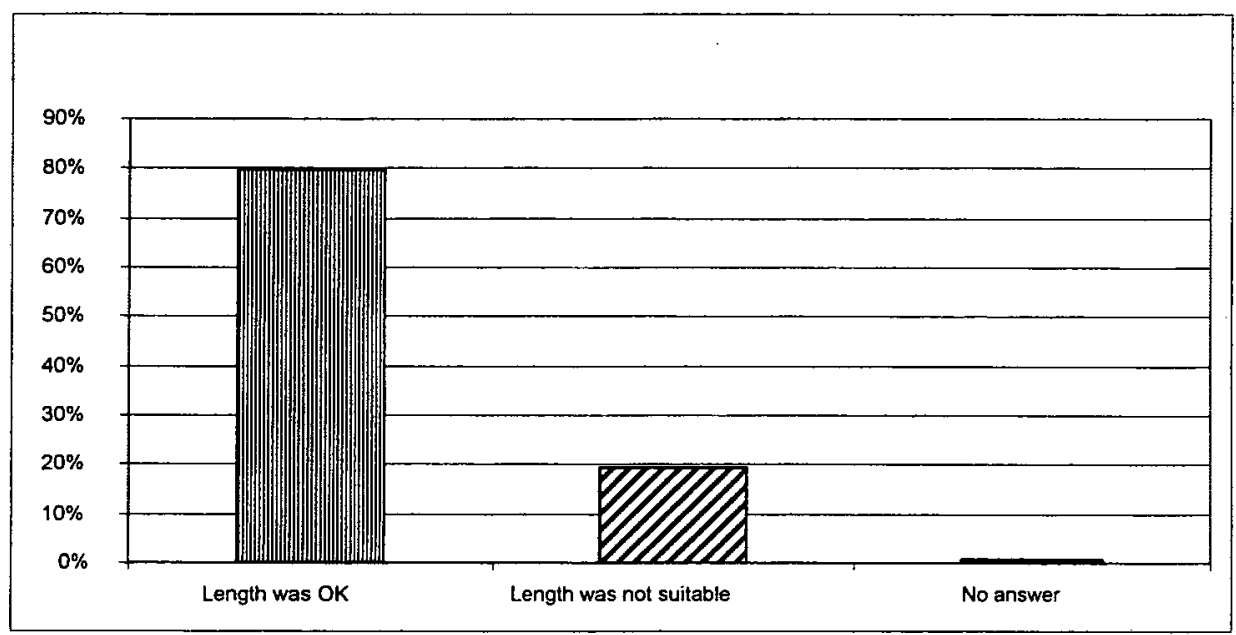

Figure 15: Members' evaluation about the length of the family worship seminar.

The seminar was evaluated as practical by 98.88 percent (177) of the participants. One person did not see it that way and another one did not answer this question. Following the same trend, 176 people $(98.32 \%)$ of the respondents agreed that the seminar introduced new ideas in relation to family worship activities, and 178 people (99.44\%) accepted that the seminar presented practical ideas for conducting this spiritual activity. 


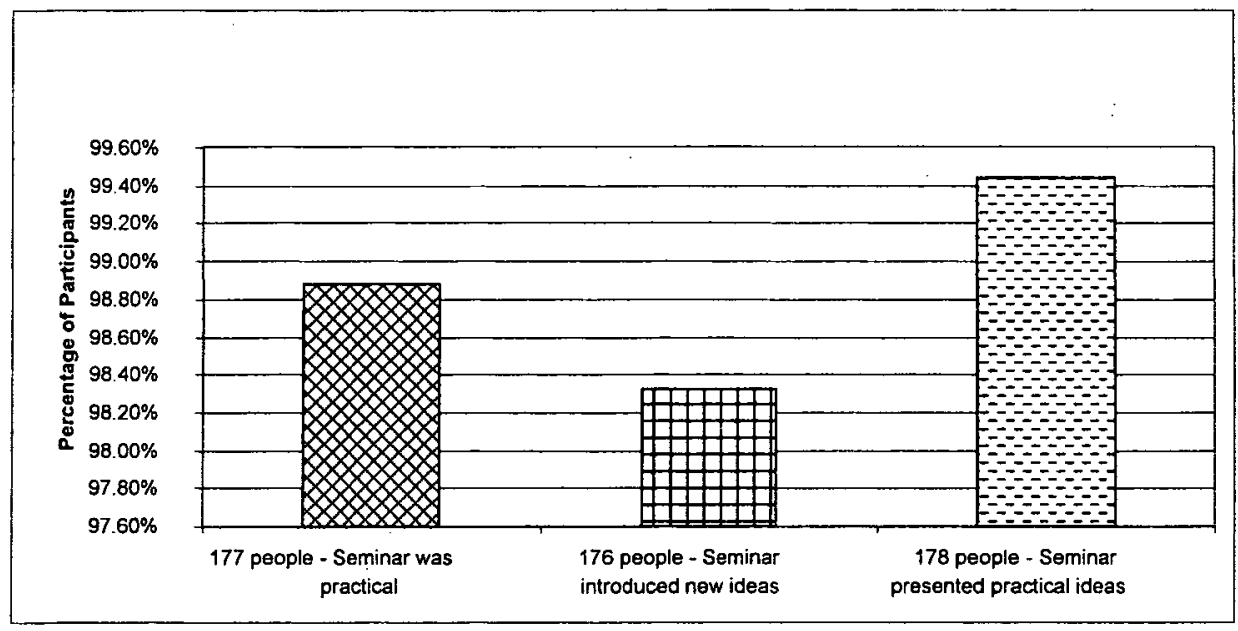

Figure 16: General practicality of the family worship seminar and the introduction and practicality of new ideas to family worship activities.

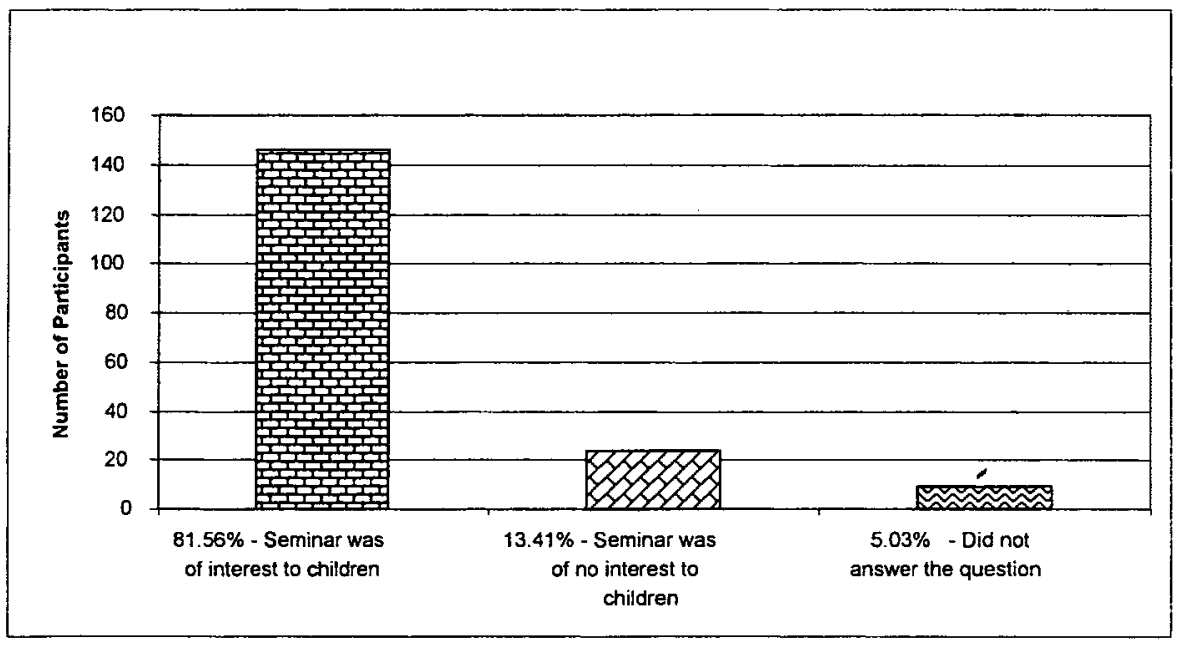

Figure 17: Level of interest of children in the family worship seminar.

Although a good majority of the people evaluated the seminar as being of interest to children, some concerns were raised when the final evaluation was tabulated. 146 people (81.56\%) affirmed that the seminar was of interest to children, while 24 respondents (13.41\%) did not agree, and 9 people (5.03\%) did not indicate their opinion on this question. A positive response to this question was considered to be vital, given 
the fact that a whole section of the seminar dealt with the preparation of a family worship program that would involve and engage children and be interesting and creative for them. Another way of evaluating this question was to take into consideration the suggestion made by some people. They claimed that they would probably have perceived the program to have gained the attention of the children and been of more interest to those present, if the relevant section dealing with family worship and children had been presented earlier in the afternoon, instead of during the last part of the seminar.

Although valid, this suggestion could not have been applied in the type of format chosen for the presentation of the seminar on that specific occasion. The fact is that in preparing the seminar, the researcher was not exactly intending to check on the interest of the children who were present during the seminar. His main objective in this section was that the participants, especially parents, became aware of the importance and content of the material designed especially to assist parents in conducting creative and inspiring family worships in their homes. In order to underscore his goal, the researcher introduced a partial practical presentation of his own family worship as a model during this segment of the seminar.

The suggestion relating to revision of the time period for presenting the section of the seminar which deals with family worship with children will be discussed further later in this chapter. At that point, the researcher will present some recommendations for future presentations of the seminar, as well as what to do next to keep the topic of family worship alive among church members.

One of the pleasing discoveries for the researcher was in relation to whether the seminar challenged parents or not. According to the final evaluation, 170 respondents 
(94.97\%) believed the seminar presented good challenges for the parents, while 4 people did not think so (2.24\%), and 5 individuals (2.79\%) did not indicate their opinion.

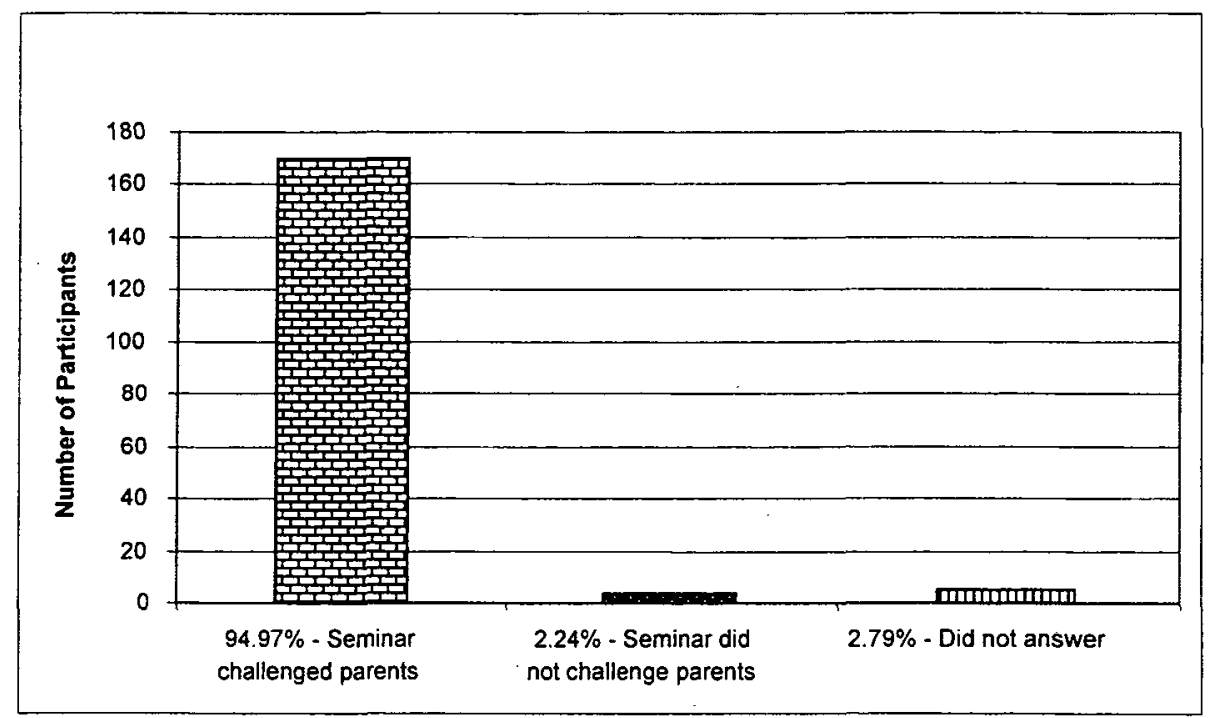

Figure 18: Level of parents who felt positively challenged by the family worship seminar.

In general, the researcher was very contented with the evaluation of the seminar, as it reassured him of the significance of the subject and its practical influence in Christian homes as a means of bringing families closer to God and promoting unity and fellowship among the members of the family. He was happy with the participation of the church members as well as their appreciation for the seminar. 


\section{CHAPTER VI}

\section{SUMMARY, CONCLUSIONS AND RECOMMENDATIONS}

This chapter presents a summary of the most important elements related to this project, as well as the results of the final evaluation of the "Our Families for God" family worship seminar, as provided by the Hamilton Mountain church members who participated. It also suggests practical recommendations aimed at making the family worship activity an attractive and rewarding experience in every home.

\section{Summary of the Project}

The Purpose of the Project

The purpose of this project was to offer a practical, creative, and attractive family worship seminar as a way of motivating and enhancing the practice of this spiritual activity among the member families of the Hamilton Mountain church.

\section{The Problem}

Christian families are constantly targeted by Satan, who wants to destroy the family entity which was created by God. The family was intended to create a closer bond and inspire us to develop an intimate relationship with our Creator. The ongoing satanic battle instigated against the family unit has brought sadness, suffering, and division 
among family members. All of these problems have also resulted in the introduction of divorce between human couples. This has dramatically increased to the extent that its escalation has permeated many Christian homes.

Youngberg says that "God's plan is that Christian families stop all activities morning and evening and recognize the living God in song, praise, Bible reading, and prayer." In this context, family worship, when practiced in the home, provides a spiritual awareness of God's presence and His blessing on the family members. It offers them an opportunity to relate to God as their Creator and it also acts as a reunifying agent in helping to restore and/or improve the relationship between family members and God.

Because of all of these benefits, "Our Families for God" family worship seminar was designed with the intention of providing the Hamilton Mountain Church members with practical exposure to the subject of family worship. The seminar aimed to raise their awareness of the significance of topic and to assist them in improving the practice of this spiritual activity in their homes.

\section{Review of Literature}

The main theme of the project was related to family worship. In order to provide the best possible information about the origins of family worship, the biblical Old Testament concept of altar-building by the patriarchs and the gathering together of their families, usually initiated by the head male figure or father, presents as an indication of the presence and practice of this activity in their homes. In addition is the evidence of the strong and organized family ties exemplified by the Old Testament Jewish families who considered their homes as their sanctuaries, in which their children received instruction in

\footnotetext{
${ }^{1}$ Youngberg and Youngberg, 80.
} 
the Torah. Jewish parents followed the instructions outlined by Moses in Deut 6:1-9. This information helped to enlighten this research on the importance that the Jewish nation placed on the spiritual instruction and education given to children in their homes. This provided a clear suggestion about the presence of this family worship type activity in their homes. The frequency of such practices was highlighted through the ritual of the morning and evening sacrifices followed through the tabernacle ordinances.

The New Testament offers the example of Lois and Eunice training Timothy from his early childhood. This indicates the practice and importance of family worship in preparing one to serve and love God, with special focus and attention dedicated to children. Also, the fact that the New Testament church was born in the homes of the believers, which naturally became the center of all their religious activities, could be a sign of their practice of family worship. The political situation of those days would not allow the public practice of the Christian religion, so if the believers held their gatherings in their own homes, this could also offer a clue pointing towards their potential practice of family worship.

The literature available dated before the seventeenth century does not describe a form of family worship as its is known today, except for a few minor references to family prayers and readings, dated about the time of the Middle Ages and Reformation. This research has endeavored to present the development of some structured form of family worship that could be traced back to the period of the Puritans, when singing, praying, reading, and reflection were incorporated as a family worship model by that group of people. 
This research has also expanded on the importance and emphasis given to family worship in Adventism. The views and counsels of Ellen G. White in dealing with the subject were presented as the ideal for this activity, from the standpoint of Adventism. She wrote extensively on the topic and this study devoted a whole section in the second chapter to a presentation of her position and beliefs in relation to family worship.

\section{Conclusion}

It has been extremely rewarding for the researcher to discuss and promote the topic of family worship with his church members. During the months of his private research he was positively impressed with the attention given to this topic by current Christian authors. Nonetheless, the amount of counsel, suggestions, and ideas available in the writings of Ellen White related to this subject caused him to reflect deeply on the importance of this activity for the family. He is grateful to God for the words of divine inspiration that he received through her books and articles.

On the practical side, this project has demonstrated that the involvement of the church members was decisive in gaining their interest and participation in the family worship seminar, which was its ultimate goal. To facilitate this objective, the researcher focused on different approaches to bring about the necessary awareness of the topic of family worship and to engage them in this project.

In order to achieve these purposes, the members were introduced to the significance of the topic through a series of sermons and children's stories, delivered to them by three different presenters in a specific month. Following this, they were also encouraged to participate in a questionnaire related to the topic. Afterwards the results of the questionnaire were made available through a PowerPoint presentation. At a later 
stage, "Our Families for God," a family worship seminar was designed based on the needs and expectations of the members as they were expressed in the questionnaire and as sensed by the researcher through the ideas and suggestions stated in that instrument. The climax of the project was reached when the family worship seminar was presented at the church, on a specially promoted occasion, a Family Sabbath Day, November 25, 2006. The preparations for the event and the atmosphere in the church highlighted the theme in a very special way. The church was decorated appropriately, lunch and supper were prepared for the members, seminar materials such as work-sheets, pens, etc., were distributed, and the church's big screen was utilized for four PowerPoint sections of the presentation, to an attentive and interested congregation who represented a large proportion of the membership.

Another encouraging sign of a positive response from the church was the reasonable percentage of members who were also involved in making their final evaluation of the seminar. During the process of finalizing the project, the researcher, with the assistance of his wife, Angela Torres, presented a Creative Family Worship Workshop at the church on February 18,2007 . This was a practical program designed to assist parents and family members to prepare props, decorations, and illustrations for their family worship activity, especially for those who have children at home. This workshop was in response to a request made by some of the participants of "Our Families for God" seminar, as they visited the creative arts station for family worship that was displayed during the last segment of the seminar. Finally, in the last stage of his project, the researcher presented the results of the final evaluation of the seminar to the 
congregation, as a way of motivating them to apply the information they had received, in their family worship activity at home.

The researcher was convinced of the importance of the topic of family worship throughout the various stages of his project, during which he could perceive the interest of the members. He was confident that he was addressing an area of spiritual need for his congregation. Also, according to the researcher's discoveries, his efforts to gain the members' involvement during the course of this project simply helped them to develop a sense of ownership with this endeavor, which in his judgment, was appreciated by them. In addition, he was left with the assurance that his congregation esteemed the materials presented and were pleased with his attempts to bring them not only a theoretical awareness of the topic, but especially some practical knowledge and ideas on this vital matter.

\section{Recommendations}

Despite of the fact that the researcher identified the overall results of his project as very positive for his particular congregation, he could also detect some areas that needed improvement in order to generate greater success in future presentations of "Our Families for God" family worship seminar. These areas are itemized below:

1. The researcher has realized that although the format of a full day seminar was beneficial to accomplish the purpose of having all evaluations made available to him immediately, it would have probably been more productive and less tiring, both for the congregation and himself, to have presented the seminar over two separate occasions. In reference to future presentations, the format of a weekend, Friday and Saturday, or perhaps two consecutive Sabbaths could probably work better to address this issue of 
seminar time and length. The reality of course, is that in forthcoming presentations the researcher will not be pressured to collect evaluations with the purpose of having an indication of interest and/or numeric participation of people in the seminar. Future participants of the seminar would be offered an evaluation form only as a means to assist him in improving the quality of the content and presentation.

2. There were some reasons for which the researcher decided to make the presentation of the section dealing with family worship with children as the last one when he presented the seminar to his congregation. In the original seminar format that was presented to the Hamilton Mountain church members and parents, the first concern of the researcher was to introduce the biblical and theological foundation, characteristics, benefits, general observations, and ideas that are related to family worship. His intention was to present the participants with a broad assessment of the topic, as well as to impress upon their minds and hearts the importance of the subject. Only after such a review was he able to effectively bring some suggestions and ideas for family activities with children, which was also part of his endeavors to address in the seminar.

In future presentations of the seminar, which would probably take the format of being spread over two or more days, this section should be highlighted as a special treat. It could well engage parents and all children and devote attention to their special needs. It may include a full practical example of a family worship program, modeled for the parents and children.

3. The topic of family worship should continue to be presented to the church on a regular basis. This could include more sermons to the congregation and positive messages and testimonies from church members who practice family worship, in order to 
motivate and inspire others to adopt this practice. Presentation of children's stories relating to family worship during congregational worship and perhaps even a space in the church bulletin promoting the practice of family worship could be beneficial and maintain the interest of all members.

4. Church members should be also reminded about the importance of this spiritual activity through the introduction of practical workshops related to the theme. The pastor and the Family and/or Children's Ministries departments should lead out in promoting these to the church. Family worship needs to be perceived as a daily and practical experience that ideally should be practiced in all Christian homes. In order to help parents to achieve this goal, they need to be trained to prepare materials, props, and illustrations for their family worship activities. Family members, especially parents, must be supported through new ideas and practical hands-on activities that also challenge their creativity in designing an interesting and fitting family worship appropriate to their individual situations. The church must be also willing to promote practical seminars and workshops on topics related to worship, prayer, and Bible study. These programs will engender ideas which could be applied to family worship.

5. This seminar itself could be presented again to the church in a couple of years, incorporating some revision and adaptation, as well as new materials which would have become available. Alternatively, it could be used in the church's small groups meetings, in individual sections, as a way of promoting this spiritual activity. This would certainly introduce some non-members to the topic. In this way, the goal of making family worship a powerful witnessing tool could also be addressed when this recommendation is put into practice. 
6. This seminar could be presented to other churches in order to assist them in promoting this spiritual activity among their members. 
APPENDIX A:

Family Worship Questionnaire 
March 15, 2006

Dear Church Member:

Greetings to you in the name of Jesus Christ!

As you are aware, I am pursuing my Doctoral Studies at Andrews University and have fulfilled most of the requirements of the Doctor of Ministry program. Currently, I am working on my dissertation on the topic of "Family Worship."

At present, I am in the process of making my dissertation a viable project that will spiritually benefit our Hamilton Mountain Church. During the last two Sabbaths (March 04 and 11), Mrs. Donna Jackson (Ontario Conference Family Ministries Director) and I preached about "Family Worship" in order to arouse your interest on the subject.

The goal of my dissertation is to design a "Family Worship Seminar" for our church. This is where I need your help. Attached to this letter is a questionnaire that seeks information pertaining to your Family Worship and it is divided into two parts. The first part and the last two questions of the second part (questions 59 and 60) are designed for all members who are twelve years of age or older. The second part has questions related to parents or grandparents whose children are still living at home, only. Therefore, those who have children living with them are requested to answer all questions on both parts of the questionnaire. I would be grateful if you would take a few minutes of your time to complete the questionnaire.

Thank you for your sincere answers and suggestions. This will surely assist me in measuring the practice and reality of Family Worship in our church. All of this, including your suggestions on how to make Family Worship relevant and interesting will help me in preparing a seminar on this topic which will be presented to the church at a later stage, along with evaluation responses which will be collected at the same time.

Please complete this questionnaire and return it in the enclosed self-addressed stamped envelope by March 31 $1^{\text {st }}$. This will give me time to proceed with the proposed schedule to finish my dissertation (project) and provide you with a sense that you were a part of this project, too. Precautions have been taken to avoid any form of identification of the participants and all answers will be treated as strictly confidential.

If you need any further information, please feel free to contact at (905) 304-9024.

Thank you for your help.

God Bless You!

Pr. Wesley Torres 


\section{Family Worship Questionnaire \\ Part I - General Information about Your Family Worship}

Please mark with a $\sqrt{ }$ (inside of the space provided) your answer for each question

1. Gender $\quad \square$ Male $\quad \square$ Female

2. Age $\square 12-16$ years

$\square 17-20$ years

$\square 21-30$ years

$\square 31-45$ years

$\square 46-60$ years

$\square$ Over 61 years

3. Education

$\square$ Primary incomplete

$\square$ Primary complete

$\square$ Secondary incomplete

$\square$ Secondary complete

$\square$ College or higher

4. Have you ever practiced family worship in your life?

口 Yes

$\square$ No - If you ticked "NO." please return the questionnaire without answering any of the remaining questions. Thank you for your participation in this study.

5. Are you practicing family worship now?
$\square$ Yes
$\square$ No

6. What is the frequency of your family worship?

$\square$ Daily

$\square$ Frequently (often)

$\square$ Occasionally

$\square$ Never

7. How did you "adopt" family worship?

$\square$ Grew up in a family that practiced family worship

$\square$ Grew up in a family that did not practice family worship but decided to have it after marriage or birth of a child

$\square$ I was influenced by a friend or a church family who practiced family worship

$\square$ I was influenced by messages/sermons about family worship

$\square$ Other (Explain):

8. Do you have any set time for family worship?

$\square$ Yes

$\square$ No 
9. At what time (s) of the day do you have family worship?

10. Do you practice any personal devotion besides family worship?
$\square$ Yes
$\square$ No

11. What is the most common place for your family worship?

$\square$ Living room

$\square$ At the dinner table

$\square$ Parents' bedroom

$\square$ Child's (children's) bedroom

$\square$ Other (Explain):

12. What are the parts (elements) of your family worship? ( $\sqrt{ }$ all applicable)

$\square$ Bible reading

$\square$ Prayer

$\square$ Songs

$\square$ Multimedia (Videos, Cds, Dvds, Tapes, etc)

$\square$ Sabbath School lesson study

$\square$ Morning devotional reading

$\square$ Bedtime (Bible) stories for your child (children)

$\square$ Other (Explain):

13. How would you evaluate your family worship experience?
$\square$ Outstanding
$\square$ Good
$\square$ Average
$\square$ Below average
$\square$ Poor
$\square$ Very poor

14. Main reasons that sometimes affect the practice of your family worship
$\square$ Lack of time
$\square$ Tiredness
$\square$ Work related commitments
$\square$ Lack of planning
$\square$ Lack of interest
$\square$ Other (Explain):

15. How can you improve the level and frequency of your family worship?

$\square$ Need to pray for spiritual interest

$\square$ Need to improve time management

$\square$ Study more about the subject

$\square$ Seek counsel from friends who have a successful family worship

$\square$ Acceptable the way it is

$\square$ Other (Explain): 
16. What are the most important parts of family worship? ( $\sqrt{ }$ all applicable)

$\square$ Bible reading

$\square$ Prayer

$\square$ Songs

$\square$ Multimedia (Videos, CDs, DVDs, Tapes, etc)

$\square$ Sabbath School lesson study

$\square$ Morning devotional reading

$\square$ Bedtime (Bible) stories for your child (children)

$\square$ All of the above

$\square$ Other (Explain):

17. How long is your family worship?
$\square$ Up to 10 minutes
$\square$ Up to 20 minutes
$\square$ Up to 30 minutes
$\square$ More than 30 minutes

18. In your opinion, what is most relevant to the family worship time?

$\square$ Length of family worship

$\square$ Contents of family worship

Both of them

$\square$ Other (Explain):

19. Who takes the initiative at home for family worship?

$\square$ Husband (Father)

$\square$ Wife (Mother)

$\checkmark$ Children

$\square$ Nobody

20. What best describes your motivation to practice family worship?

$\square$ Desire for a personal communion with God

$\square$ Desire for family communion with God

$\square$ Personal accountability before God

Accountability for my children before God

Tradition / Habit / Routine

$\checkmark$ Other (Explain):

21. Do you believe that family worship gives you the sense that Jesus is real in your live?

$\square$ Yes

$\square$ No

$\square$ Uncertain

22. Do you believe that family worship promotes the religious heritage in your family?
$\square$ Yes
$\square$ No
$\square$ Uncertain
$\square$ Not Applicable 
23. Does the practice of family worship strengthen your hope in the second coming of Christ?
$\square$ Yes
口 No
$\square$ Uncertain

24. Does family worship improve your appreciation for the Sabbath day?

$\square$ Yes

$\square$ No

$\square$ Uncertain

25. Does family worship help you to claim the merits of Christ's blood for the pardon of your sins?
$\square$ Yes
$\square$ No
$\square$ Uncertain

26. Do you accept that family worship is a special time when God blesses your family?

$\square$ Yes

$\square$ No

$\square$ Uncertain

27. Does your family worship encourage your family members to pray?

$\square$ Yes

$\square$ No

$\square$ Uncertain

28. Does your family worship activity bring your family members closer to each another?

$\square$ Yes

$\square$ No

$\square$ Uncertain

29. Does family worship sponsor respect and reverence for the Word of God?

$\square$ Yes

$\square$ No

$\square$ Uncertain

30. Do you believe that family worship promotes the spiritual growth of your family?
$\square$ Yes
○ No
$\square$ Uncertain

Thanks for completing this part of the questionnaire. If you are not a parent or grandparent whose children are still living at home with you, please go to the last page (page 9) and answer questions 59 and 60 now. The second part of this questionnaire (questions 31-60) should be completed in full only by those who have children living at home with them. 


\section{Part II - Family Worship with Children}

\section{Please answer all questions of part II only if:}

\section{* You are a parent or grandparent with a child or children at home.}

31. How many children in your household?

$\square$ One

$\square$ Two

Three

More than three

32. Age (s) of your child (children):

$\square 1-4$ years

$\square 5-8$ years

$\square 9-12$ years

$\square 13-16$ years

$\square$ Over 16

33. When family worship time is announced, what is your children's first reaction?

$\square$ They come to worship at the first call

They come to worship at the second or third call

$\square$ They show indifference

$\square$ They pretend not to hear the call to worship

$\square$ They need to be brought to attend the worship time

34. What is your children's attitude during the worship time?

$\square$ They show enjoyment attending family worship

$\square$ They show indifference - usually doing something else during the worship

$\square$ They attend because they are forced to

$\square$ They sleep during the worship

35. What is your children's response at the end of your family worship?

$\square$ Ask to continue the worship time

$\square$ The worship time was just right

$\square$ They are tired and they feel happy the worship time is over

口 Uncertain

36. How much weekly time do you spend in preparation of materials, music, etc for the worship time with your children?

$\square \mathrm{Up}$ to 30 minutes

$\square$ Up to 1 hour

$\square$ Up to 2 hours

$\square$ More than 2 hours

$\square$ None 
37. What segment of family worship is most appreciated by your children?

$\square$ Children's Sabbath School lesson study

$\square$ Songs

Prayer

Stories

Bible reading

Multimedia (Videos, CDs, DVDs, Tapes, etc)

Morning Devotional Reading

Bedtime (Bible) stories for your child (children)

$\square$ Other (Explain):

38. What segment of family worship is least appreciated by your children?

$\square$ Children's Sabbath School lesson study

$\square$ Songs

$\square$ Prayer

$\square$ Stories

$\square$ Bible reading

$\square$ Multimedia (Videos, Cds, Dvds, Tapes, etc)

$\square$ Morning Devotional Reading

Bedtime (Bible) stories for your child (children)

$\square$ Other (Explain):

39. Do your children take an active part in your family worship?
$\square$ Yes
$\square$ No

40. In which part are your children most often involved?

$\square$ They pray

They lead out in songs

$\square$ They read or present their Sabbath School lesson

口 Play musical instruments

$\square$ Ask questions

$\square$ Other (Explain):

$\square$ None

41. Have you ever allowed your children to lead out in family worship?

$\square$ Yes

$\square$ No

42. How frequently do your children lead out in family worship?

$\square$ More than two times a week

$\square$ Once a week

$\square$ At Friday / Sabbath Sunset Worship

$\square$ Once a month

$\square$ Very seldom

$\square$ Never 
43. Do you believe that the practice of family worship has a positive influence in the lives of your children?
$\square$ Yes
No
Uncertain

44. Which of the following worship activities do you think would create a positive influence in the lives of your children?

$\square$ Teaching them about the importance of communion with God

Teaching them about the good example of Biblical figures

Teaching them obedience and reverence

Teaching them about life's values

$\square$ Other (Explain):

45. Which aspect of this influence is most perceived in the lives of your children as you gather together for family worship? $(1=$ least important, $5=$ most important $)$

$\begin{array}{llllll}\square \text { Develop love towards God } & 1 & 2 & 3 & 4 & 5\end{array}$

Develop their character

$\begin{array}{llllll}\square \text { Obedience to God \& parents } 1 & 2 & 3 & 4 & 5 & \\ \text { Relationships with other children } & 1 & 2 & 3 & 4\end{array}$

$\square$ Other (Explain):

46. Have you ever perceived any positive influence in the lives of your children as a result of family worship?

$\square$ Yes

$\square$ No

$\square$ Uncertain

47. How did you observe this influence on them?

$\square$ Through their relationship with their parents

$\square$ Through their relationship with friends and neighbors

$\square$ Through their relationship with other children

Behavior at church

$\square$ Behavior at school

$\square$ Other (Explain):

$\square$ Not Applicable

48. Have you noticed any of the following attitudes in the lives of your children as a direct result of the influence of your family worship?

$\square$ Forgiveness

$\square$ Unselfishness

$\square$ Kindness

[-Generosity

Respect

$\square$ Other (Explain): 
49. Do you believe that family worship helps to develop a spiritual awareness in your children by allowing them to develop a better perception of God?

$\square$ Yes

$\square$ No

$\square$ Uncertain

50. Would you like your children and their future families to practice family worship?

$\square$ Yes

$\square$ No

$\square$ Uncertain

51. Considering the period when you were a child / young person and family worship was practiced in your parents' home, do you believe that it has influenced you to have family worship with your children?
$\square$ Yes
$\square$ No
$\square$ Uncertain
$\square$ Not Applicable

52. Do you believe that the children's Sabbath School lesson helps in the spiritual development of your children?

$\square$ Yes

$\square$ No

口 Uncertain

53. Do you believe that your family worship activity helps to prepare your children for the Sabbath School program at church?
$\square$ Yes
$\square$ No
$\square$ Uncertain

54. Does the Children's Sabbath School program motivate your children's participation in your family worship?
$\square$ Yes
$\square$ No
$\square$ Uncertain

55. Do you believe that the teachers of the Children's Sabbath School department have contributed to the spiritual growth of your children?
$\square$ Yes
$\square$ No
$\square$ Uncertain 
56. How did you become a Seventh-day Adventist?

$\square$ I was born into an Adventist family / home

$\square$ I became an Adventist with my family (parents \& siblings) when I was a child

$\square$ I became an Adventist by myself when I was a child

$\square$ I became an Adventist with my family in my youth

$\square$ I became an Adventist by myself in my youth

$\square$ I became an Adventist as an adult with my family (husband or wife \& children)

$\square$ I became an Adventist by myself as an adult

$\square$ Other (Explain):

57 . How can you improve your family worship with your children?

a.

b.

c.

58. What are the greatest needs in your family worship to make it attractive and relevant for your children?

a.

b.

c.

59. Suggestions for a successful family worship

a.

b.

c.

60. What would you expect from the "Family Worship Seminar" that will be developed from this study?

a.

b.

c.

Thank you very much for completing this questionnaire. 
APPENDIX B:

Family Worship Seminar 


\section{"Our Families for God"}

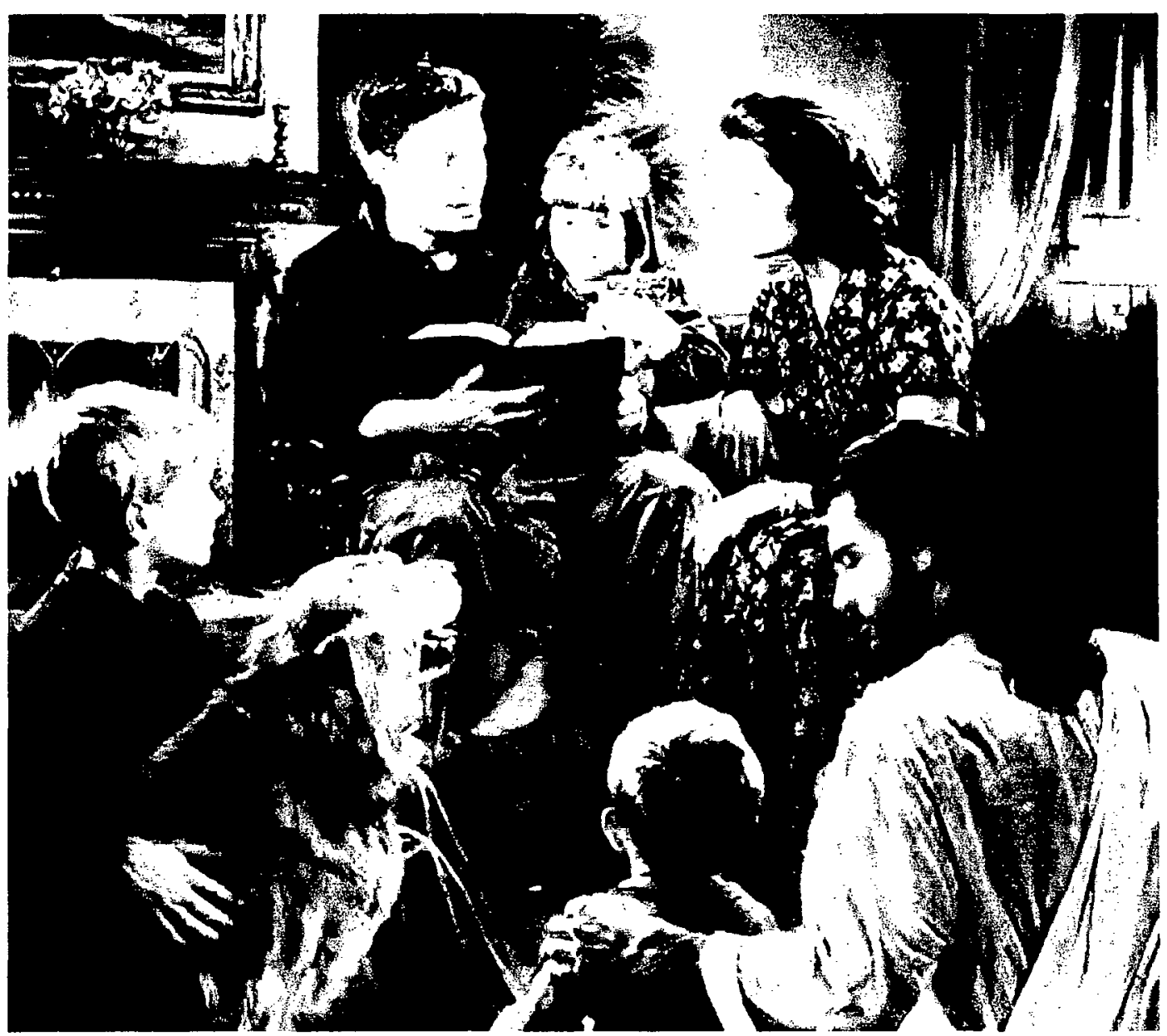

A Family Worship Seminar

Hamilton Mountain Church

Pr. Wesley Torres

November 25, 2006 
November 25, 2006

Dear Church Member and Friend,

Welcome to "Our Families for God" Family Worship Seminar!

Today is an exciting day! After many years of preparation, hard study, long nights, and separation from my family when I had to leave them behind in Australia and go to attend the D.Min. classes at Andrews, I am glad to present the practical part of my dissertation for my doctoral studies to you. It comes to you in the format of a Family Worship Seminar entitled "Our Families for God."

In March of this year, a considerable percentage of our Hamilton Mountain Church members completed a Family Worship questionnaire that formed the backdrop of this seminar. The findings and suggestions received through this instrument assisted me in preparing today's seminar. I pray that you and your family, along with all who attend, will be abundantly blessed through this experience.

Please, pray for the Holy Spirit to move softly and gently among us today as we study this important topic. I also covet your prayers to have the ability to speak clearly, directly, and with the authority of the Scriptures as we embark on an adventure of joy and discovery about this vital subject of Family Worship. I am more than ever convinced that God wants our families to be stable, happy, and enjoy a daily spiritual relationship with Him.

Thank you for your participation and also for being part of our Hamilton Mountain Church family on this occasion. This day has been set aside months ago as our "Family Sabbath Day."

Now, it is time for us to celebrate it together!

May God bless us all!

Your friend and pastor,

Wesley Torres

D.Min. candidate

Andrews University 


\section{“OUR FAMILIES FOR GOD” FAMILY WORSHIP SEMINAR}

First Section

"The 'Why' of Family Worship"

The question "why" requires a "because" answer. Then, it becomes imperative to define the words "Family" and "Worship," in order to understand the combination and meaning of both words together.

\section{Part I - Definition of Words}

Defining Family

a) Dictionary definition: The word family is defined by the Oxford Dictionary, (308), as a "Group of parents and children," and/or "Group of living things (plants, animals, etc.) or of languages, with common characteristics and a common source."

b) Biblical definition: It varies in the Old and New Testaments. The Old Testament uses the words mishpachah and bayith for family. Mishpachah refers more to patriarchal clan, while bayith usually refers to a place of residence. But the phrase $b e t h$ ' $a b$, which means father's house, is probably the closest to the modern understanding of nuclear family. In the New Testament, the Greek words paria, oikos, and oikia are related to family, but none of them really represent today's understanding of a family comprised of father, mother, children, grandparents, etc. From these examples, one can conclude that the biblical emphasis is on family lineage that points to God as the head of the family and being One of much greater value (Matthew 23:9, John 8:41-42).

Theologically speaking, we can say that we came from God who is our Creator and He has some purpose for the human family. 
According to Herbert Anderson (Family and Pastoral Care, 15-16), the theology of the family involves two purposes: The first is that it is a necessary component of creation as it guarantees the continuity of the human species. The second, as taught by Christ, is that the family cannot be an end in itself, as it needs to enlarge its boundaries for others to come and join as the family of God.

C. A. Wood, in the article "Family Worship," (Advent Review and Sabbath Herald, May 14, 1931, 19), says that "The family is the first institution in this world, and lies at the basis of everything that is good in society."

Ellen White comments on Family:

"Let love and tenderness be exercised, especially in your family, and you will receive a blessing." (Testimonies 2:439).

"God desires that heaven's plan shall be carried out, and heaven's divine order and harmony prevail, in every family, in every church, in every institution.... Spiritual transformation would be seen in all our families.... When this transformation takes place, these agencies will become instrumentalities by which God will impart heaven's light to the world ..." (EGW, Adventist Home, 535).

Thus, we can sum up these thoughts by saying that God wants to use His children's families as His own instruments in bringing light and blessings to the whole world.

Defining worship

a) Dictionary definition: "Admiration or respect shown to or felt for somebody or something" and also "Reverence or respect paid to God" (Oxford Dictionary, 995). 
b) Christian definition:

1) "The root of the word 'worship' is 'weorth-scipe' - worth shape. Worshipping means literally shaping our worth or values" (Anna Laura and Edward Gebhard, Our Worships at Home, 11).

2) "Worship is man's joyful response to God's revelation" (Bernard Schalm, The Church at Worship, 11).

3) "Worship is perhaps the most profound and personal experience of the human soul" (Richard Lentz, Christian Worships by Families, 5).

4) Worship is "The wonder of the creature as he senses the presence of His Creator" (John and Millie Youngberg, Heart Tuning: A Guide to a Better Family Worship, 28).

5) Ellen White states that worship was conceived in heaven and that the angelic host worshipped God from eternity. "It was the joy of the heavenly host to fulfill the purpose of their Creator. They delighted in reflecting His glory and showing forth His praise." (EGW, Patriarchs and Prophets, 35).

6) Worship was God's first gift to humanity. After the creation of humanity in Adam and Eve, God's first gift for them was a day of rest, a Sabbath day. God desired to provide them with a special occasion on which they could adore Him as their Creator and also remember their origin.

"Thus the heavens and the earth were completed in all their vast array. By the seventh day God had finished the work he had being doing; so on the seventh day he rested from all his work. And God blessed the seventh day and made it holy, because on it he rested from all the work of creating that he had done." Genesis 2:1-3 NIV 
7) "The heart" of worship is surrender. ... "But surrendering to God is the heart of worship. It is the natural response to God's amazing love and mercy. We give ourselves to him, not out of fear or duty, but in love, 'because he first loved us." (Rick Warren, The Purpose Driven Life, 77).

After all these definitions, what would be our conclusion as to the meaning of family worship? It can be summarized as:

1. The most important purpose of family worship is to worship God.

2. Family worship also provides the family members with an opportunity to enjoy a daily private and personal communion with God.

3. Family worship assists the family in preserving itself as a unit over time.

4. Family worship is the surrendering of the family's heart to God.

Conclusion

So, why family worship? Because family worship is a family-effective visit with God on a daily group basis to strengthen both the affectionate and spiritual bonds of the family.

\section{Part II - Why Worship God?}

This section will endeavor to present the reasons why we are supposed to worship God. We will use the Scriptures to show the basis for such worship owed to Him.

\section{A. God is our Creator.}

"The Lord God formed the man from the dust of the ground and breathed into his nostrils the breath of life, and the man became a living being." (Genesis 2:7). This passage gives evidence that God is the Creator of all human beings. 
B. God is the Sustainer of our Lives.

"O Lord, you preserve both man and beast. How priceless is your unfailing love! ... For with you is the fountain of life; in your light we see light." (Psalm 36:7, 9). Here the Psalmist expresses his faith in God as the sustainer of all living creatures and things.

C. God is our Savior in Jesus Christ.

"For God so loved the world that He gave His one and only Son, that whoever believes in Him shall not perish but have eternal life. For God did not send His Son into the world to condemn the world, but to save the world through Him." (John 3:16-17). This text shows that Jesus is our Savior and, because of His death, those who accept Him as their Savior can have eternal life.

D. The worship of God is our grateful and loving response to His goodness.

We worship God because we recognize His love as it is revealed in the life of Jesus and in His plan of salvation for us. "We love Him because He first loved us." (I John 4:19).

E. Worship enhances our faith in God.

The worship of God leads us to recognize our dependence of Him. It also develops a closer and personal relationship between us and the One Who is our own Creator. 


\section{Part III - What is Family Worship?}

Since we have already defined the words 'family' and 'worship' and established the reasons why we should worship God, it becomes imperative to understand what family worship is all about.

A. Family worship is a spiritual activity that promotes faith in our families.

In the article 'Family Worship,' W. M. Beach declared that, "We feel our worship period has strengthened our faith and has given faith to our children.... It has helped us to gain strength to fight the good fight of faith daily." (Review and Herald, September 24, $1970,9)$.

B. Family worship is a spiritual activity for the family.

Family worship provides the family members with the opportunity to enjoy a regular private and personal communion with God. In the quietness of the home, God's Spirit speaks softly to each member, bringing His blessings to them.

Ellen White endorses family worship as the family's spiritual activity.

"In every family there should be a fixed time for morning and evening worship. How appropriate it is for the parents to gather their children about them before the fast is broken, to thank the heavenly Father for His protection during the night, and to ask Him for His help and guidance and watch care during the day! How fitting, also, when evening comes, for parents and children to gather once more before Him and thank Him for the blessings of the day that is past." (EGW, Testimonies, 7:43).

C. Family worship makes the religious life of the family practical and alive.

Family worship gives the family members the opportunity to gather together to express their feelings of love, gratitude, and respect for God. It also offers the family the chance to share mutual love, spiritual ideals and concerns, and interest in one another. It is a fellowship time for the family with God and also between the family members with one another. 
"True family worship is a fountain that brings streams of holy influences into every part of the household. It is a vase of perfume that sheds fragrance over all. It softens asperities. It quells anger. It quiets impatience. It settles differences. It subdues evil passions. Hearts that are drawn together at God's feet every day cannot get very far apart." (G. B. Thompson, "Family Worship," Review and Herald, November 12, 1914, 5).

D. Family worship is the field of applied religion for the family.

It promotes a strong spiritual relationship among the family members and between them and God.

"And Christian parents will see to it that the institution of family worship is established and maintained in their homes, else the knowledge and practice of religion will die out of those homes." (Arthur W. Spalding, "The Family Altar," Our Homes, April 3, 1924, 11).

E. Family worship is a "source of spiritual strength" that helps the family to stay as a unit.

The time invested with God as the family meets together to worship Him, helps each family member to grow in their experience with God. It brings them closer to God and to one another as it expels the enemy from their place. Ellen White also writes about the importance of practicing this activity as well as the prayers offered during family worship.

"Satan makes every effort to lead people away from God; and he is successful in his purpose when the religious life is drowned in business cares, when he can so absorb their minds in business that they will not take time to read their Bibles, to pray in secret, and to keep the offering of praise and thanksgiving offering on the altar of sacrifice morning and evening." (EGW, Christian Service, 209). 


\section{Summary}

Family worship is a spiritual activity that promotes faith in families.

Family worship is the spiritual activity for the family.

Family worship makes the religious life of the family practical and alive.

Family worship is the field of applied religion for the family.

Family worship is a 'source of spiritual strength' for the family to stay as a unit.

\section{Part IV - Biblical Examples of Family Worship.}

It is of vital importance for one to research the Scriptures to find the examples of family worship that are depicted there.

In the Old Testament

1 - Before sin: Adam and Eve (couple) worshipped God face to face.

"The holy pair were not only children under the fatherly care of God but students receiving instructions from the all-wise Creator. They were visited by angels and were granted communion with their Maker, with no obscuring veil between." (EGW, Patriarchs and Prophets, 50).

2 - After sin:

a) Noah: After the flood he built an altar for him and his family to worship God, even before building a house for himself. (Genesis 8:20).

b) Youngberg says that the habit of the patriarchs in building altars is an important element of the OT concept of family worship. (Youngberg, Heart Tuning: A Guide to a Better Family Worship, 22-23). 
c) Ellen White writes about Abraham. She says that, "Wherever he pitched his tent, close beside it was set up his altar..." (EGW, Patriarchs and Prophets, 128).

d) The Seventh-day Adventist Bible Commentary mentions the example of Jacob. It says on his journey to Egypt, he gathered his entire household around an altar to worship God, and he offered sacrifices to God. (1:466).

In the New Testament

a) The New Testament does not provide a clear description of the practice of family worship as it is known today. However, we can still find some evidence in the context of the life of Timothy.

b) The example of Timothy: Lois (grandmother) and Eunice (mother) exercised a great influence on his spiritual life by studying the Scripture with him in his childhood. In his second epistle to Timothy, Paul commends him for his faith and instructions received from his mentors. This serves as a hint about the devotion of these women, the spiritual time, and interest they invested with Timothy as a form of family worship.

"I have been reminded of your sincere faith, which first lived with your grandmother Lois and in your mother Eunice and, I am persuaded, now lives in you." (II Timothy 1:5). “... and how from infancy you have known the Holy Scriptures, which are able to make you wise for salvation through faith in Christ Jesus." (II Timothy 3:15).

\section{Ellen White and Timothy}

"From a child he had known the Scriptures. The piety that he saw in his home life was sound and sensible. The faith of his mother and his grandmother in the sacred oracles was to him a constant reminder of the blessing of doing God's will. The Word of God was the rule by which these godly women had guided Timothy. ... Thus, his home instructors had co-operated with God in preparing him to bear burdens." (EGW, Acts of the Apostles, 203). 
The Jewish Tradition

a) The home has always been the center of religious life for the Jews. They conveyed their religious instructions and the education of their children within its perimeters.

b) The Jewish families always referred to their homes as their sanctuaries. On several occasions they experienced exile, causing them not to have a temple in which to worship God. These situations simply made their homes even more important places for the worship of God.

c) The home was set aside for the special purpose of the worship of God, the learning of the Torah, and as a place to serve community needs. Within their homes, they set their expectations about the private instruction of their children. They were also a place used to bring blessing to their communities.

d) The father acted like the priest of his household and he ministered to his family. He was entrusted to study the Torah and the rolls of the prophets with his family. He was the one responsible for praying and interceding for his family before God.

\section{Part V - Family Worship - The Family Altar}

The expression "The Family Altar" has always been identified as the spiritual meeting conducted by families, as the members worship God together in their homes.

1. Home - A sanctuary for the family.

Christians' homes should be seen as a place where God is honored and exalted through the practice of family worship. In this sense, it is called the "Family Altar." 
"Central to all religious teaching in the home is the institution of family prayers, or, in the figurative term that is often used, the family altar." (Arthur W. Spalding, "The Family Altar," Our Homes, April 3, 1924, 11).

2. Ellen White counsels that the "Family Altar" needs to be part of the family's daily plan. She uses the earthly sanctuary language as she refers to the practice of this spiritual activity.

"In every Christian home God should be honored by the morning and evening sacrifices of prayer and praise." (EGW, Counsels to Parents, Teachers, and Students, $110)$.

3. The father is the priest of the house.

God has given the father the responsibility to be the spiritual leader of his family. Ellen White agrees with the role of the father as a priest for his family.

"Let the father, as priest of the household, lay upon the altar of God the morning and evening sacrifices, while the wife and children unite in prayer and praise. In such a household Jesus will love to tarry." (EGW, Patriarchs and Prophets, 144).

4. The "Family Altar" should promote the study of the Bible.

"In arousing and strengthening a love for Bible study, much depends on the use of the hour of worship." (EGW, Education, 186).

"These commandments that I give you today are to be upon your hearts. Impress them on your children. Talk about them when you sit at home and when you walk along the road, when you lie down and when you get up. Tie them as symbols on your hands and bind them on your foreheads. Write them on the door frames of your houses and on your gates." Exodus 6:6-9. 
5. The "Family Altar" brings a taste of heaven to the family.

"By building altars to the glory of God we can have a bit of heaven while living here on earth." (Beatrice Wornow, "Building Altars," Review and Herald, May 24, 1956, 12). Norman Williams agrees with Wornow as he writes:

"The Family Altar is more than a set of devotions within the home-it is in its fullest meaning to be the life of the home." (Norman V. Williams, How to Have a Family Altar, 24).

"Family Altar" - Summary

1. Home - A sanctuary for the family.

2. The "Family Altar" needs to be part of the family's daily plan.

3. The father is the priest of the house.

4. The "Family Altar" should promote the study of the Bible.

5. The "Family Altar" brings a taste of heaven to the family.

Therefore, why family worship?

Because family worship is a family-effective visit with God on a daily group basis, to strengthen both the affectionate and spiritual bonds of the family.

Have a blessed Sabbath! See you later, for the remaining sections of the Seminar. 


\title{
“OUR FAMILIES FOR GOD” FAMILY WORSHIP SEMINAR
}

\section{Second Section}

\author{
"The 'How' of Family Worship"
}

In section I we talked about the "Why" of family worship. In sections II and III we will study about the "How" of family worship. However, section II will deal with the "Characteristics of Family Worship" and the "Elements of Family Worship" bringing some suggestions to make the family worship segments more relevant and interesting.

\section{Part I - Characteristics of Family Worship}

There are important elements that need to be highlighted in order for one to understand the characteristics of this family activity. Thus, it becomes imperative to list them below.

1. Family Worship is a spiritual activity.

One of the most important things about family worship is a clear understanding that it is a spiritual activity that becomes the catalyst for the spirituality of the family. Then, these significant tenets may be added about family worship:

a) It ought to promote the spiritual growth of the family.

b) It emphasizes the spiritual relationship between God and the family, as well as between the family members.

c) It should take place in an atmosphere of peace, harmony, love, and acceptance.

d) It is a fellowship time between the family and God. It connects them with God. 
2. Family worship is a daily activity.

It is of vital importance that this spiritual activity be treated as essential for the family. Family members should receive spiritual nourishment for their spiritual growth, as much as their human bodies depend on food to survive. There are some important factors.

a) It should be conducted regularly at home.

Ellen White observes that: "In every family there should be a fixed time for the morning and evening worship." (EGW, Testimonies, 7:43).

b) It should have a consistent and fixed time.

Ellen White counsels in regard to this matter, "In every family there should be a fixed time for the morning and evening worship." (EGW, Testimonies, 7:43).

c) It should take priority in the home.

Ellen White also mentions this priority.

"In too many households prayer is neglected. Parents feel that they have no time for morning and evening worship..... From every Christian home a holy light should shine forth.... They would indeed be the "light of the world." (EGW, Patriarchs and Prophets, 143-144).

3. Family worship needs to be a structure activity.

a) It needs to involve all participants. It requires attention to address all age groups, to have meaningful contents, and to promote the participation of every member.

b) It is a time for teaching and communication.

"[Family worship] is a formalized and structured activity time of teaching and communication within the family. It is a time when family members are involved in sharing, learning, and worship." (Mary White, Successful Family Devotions, 13). 
c) It shows a God of love and a Father of order.

"Angels delight in a home where God's love reigns supreme, and the children are taught to reverence religion, the Bible, and their Creator. Such families can claim the promise: 'Them that honor Me I will honor"' (EGW, Adventist Home, 322).

4) Family worship should be Christ-centered.

Family worship should be particularly Christ-centered. The focus of this spiritual activity needs to be placed on what Christ has accomplished for His children as a means of instructing them about His salvation (John 3:16-17; 1 John 1:9; Hebrews 13:5).

Seventh-day Adventists have the privilege and duty of educating their families regarding Christ's ministry in the heavenly sanctuary, the Sabbath commandment, and the second coming of Jesus Christ. These are essential messages to be presented during their family worship, which will be converted into the perfect setting for studying and discussing these truths with the family and especially the children. Creativity should be used in how to intelligently introduce, in the family worship activity, these important subjects related to salvation.

a) Christ's ministry in the heavenly sanctuary.

During the family worship time the intercessory ministry of Christ in the heavenly sanctuary should be especially emphasized when prayers are offered to God. Family members are to be connected with Christ by faith through their confidence in Him as their mediator and the One Who knows and cares about each of them individually and as a family.

The children, too, are to be exposed to this ministry of Jesus through the artists' impressions available in the form of drawings and pictures extracted from books and magazines. They will be greatly benefited in their spiritual lives when their parents 
invest the proper time to find creative ways to instruct them by utilizing visual resources to attract their attention and make this truth simple and interesting enough to be grasped by their young minds. It will instill in the children a love and respect for Christ as their loving Savior, when they also understand His ministry in the heavenly sanctuary.

b) The Sabbath day presents Christ as the Creator.

A Seventh-day Adventist family worship that introduces these topics is ultimately highlighting the plan of salvation as it is seen in the ministry of Jesus Christ. The Sabbath commandment portrays Christ as the Creator (Hebrews 1:1-2) and also as the Lord of the Sabbath (Mark 2:28). This daily and private family spiritual activity ought to prepare the family members for corporate worship with other believers at church on the Lord's Day. Family worship time at sunset on Friday evening needs to be the climax of the week, as it is the spiritual activity in which the family welcomes the Sabbath day.

c) Family worship should highlight the second coming of Christ.

The second coming of Christ is the long awaited blessed hope for all Christians (Titus 2:13) and this sentiment needs to inspire the believers during their family worship. The believer's minds and hearts ought to be touched with the sense of awe and expectation when this message is presented. This is the ultimate message the whole Bible talks about. Jesus' second coming offers comfort and joy to the believers, as it means the end of sorrow, despair, anguish, and death (Revelation 21:4-5). All family worship should conclude on a high note of the hope, peace, and happiness that this message brings and causes the believers to long for that promised occasion (John 14:1-3). 
5. Make it lively!

a) It should be brief and full of life. (EGW, Messages to Young People, 341).

b) It should be the sweetest, most helpful time of the day (Ibid).

c) It must be short and spirited. (EGW, Child Guidance, 521).

d) It ought to be pleasant and interesting. (EGW, Testimonies, 5:335).

e) It is a sacred, but a happy time. (EGW, My Life Today, 203).

f) It dishonors God when it is dry and irksome. (EGW, Education, 186).

\section{Part II - The Elements of Family Worship}

The Christian religion can be understood through its basic elements. These are Bible study, prayer, and praise. In biblical times, home was the place where God's people prayed, offered sacrifices, and praised Him until God designed a sanctuary and asked the children of Israel to build Him a place where He could dwell with them (Exodus 25:8). That was the first biblical reference to a designated corporate house of worship.

The family home should be the place where Christian families worship God in private. There, the basic elements of religion must find the full expression of their purpose in the heart of every family member. Home ought to be a place of family worship where prayers, study of the Bible, and praises should always be cherished and practiced.

Home was designed to be the place where religion is lived and taught by words and especially by example. The influence of the home in promoting the values of 
religion to family members will only be completely evaluated in eternity. Family responsibilities in this regard are rated as highly important.

a) Bible study.

The Bible is God's gift to humanity. God reveals Himself in His Word. His plans are plainly expressed in it for the benefit of sinners. The Psalmist well describes the Bible, as "Your Word is a lamp to my feet and a light for my path" (Psalm 119:105). He purposes that His children live by the Word (Isaiah 30:21).

The study of the Bible is a vital ingredient for the worship of God. Through its study the sinner becomes acquainted with the available grace and salvation in Jesus. To worship is to be exposed to God's revealed Word and be transformed by it ( 2 Corinthians 3:18; Romans 10:17). The power of His Word touches and changes the worshippers.

The Scriptures are to be used in family worship. The reading of the Bible strengthens the faith and equips the family to face the perils and temptations of Satan. Prayer and Bible reading are essential parts of the family's spiritual activities. Christ is brought into the family through His Word and the use and appropriation of the Scriptures make God's presence to be felt at home. During the family worship time His inspired messages ought to be studied and applied in the lives of family members. It helps them to face the challenges out there, with confidence in God's promises. That is why the whole family, including children, should be instructed to love and respect God's Word. Home should be the most attractive and convenient place in which members are encouraged to study the Bible. 
Regarding this topic Ellen White counsels: "In arousing and strengthening a love for Bible study, much depends on the use of the hour of worship." (EGW, Education, 186.)

b) Prayer.

Prayer is the life of the human soul in its expression of dependence upon God and confidence in Him. It is a vital communication between the creature and the Creator.

Frederick Pelser defined prayer as," honestly opening the heart to our heavenly Father as to our best, most trusted, most understanding Friend." (Prayer Made Practical, 37). It is the dialogue between the Giver and the one who is sustained. God has all means available to Him. He is the Creator. The sustained need all things to remain alive. God is the life originator; the sustained are life-dependent. They are so different in power and nature, yet prayer is the channel that connects them directly to one another.

Prayer is an indispensable element in worship. Actually, prayer prepares the human heart to enter into a worship relationship-communion-with God and it is vital in the family home. A family without prayer is like a house without a roof for protection. Prayer not only carries away all human anxieties, it brings peace to the hearts. Family worship presents the ideal occasion for the whole family to ascend to God's presence through prayer.

"A family without prayer is like a house without a roof for protection." (Mary White, Successful Family Devotions, 41). 
c) Praise

To praise God is to adore Him and adoration is the purpose of worship. Family worship ought to include praising God privately by family members in a more relaxed way. The praise segment, when God is honored through music, is an attractive part of the worship in which all family members should have the opportunity to participate. It is an act of adoration and exaltation being itself more informal and less threatening than praying aloud or reading Scripture, especially for those who are shy or more reserved.

"The power in sacred song can enhance the family's spiritual hour." (Youngberg, Heart Tuning: A Guide to a Better Family Worship, 104).

d) Storytelling.

"... simple stories may be made plain the great principles of God's law." (EGW, Education, 185).

Storytelling, if properly done, is an attractive method of presenting a subject and it is more effective than story-reading. It opens the door of opportunity for creativity in the way the matter is introduced and discussed. In the family worship setting, this part should involve personal testimonies, daily life occurrences, and especially Bible stories in an appealing manner to draw lessons for the spiritual growth of every member.

The experiences of life that have shown God's protection in lives of family members, related accounts about other people which present moral and spiritual gain for the hearers, and the life of men and women of faith in the Bible could be well utilized in this segment of family worship. Also, parents can make use of storytelling to teach Bible stories to their children. The truth of God's love, care, and His plan of salvation could be communicated in the form of sharing the stories of the Bible heroes and especially about 
the life of Jesus. Ellen White agrees with this method as, "simple stories may make plain the great principles of God's law." (EGW, Education, 185).

e) Personal testimonies.

Family worship offers the perfect opportunity for members to share their personal testimonies. During this time they can build each other up spiritually by presenting the way God has blessed them individually and His protection over their lives.

\section{Part III - Practical Suggestions for Family Worship Segments}

The purpose of this section is to promote family worship as an activity that can be creative and interesting for all family members.

1) Make Bible Study a Pleasure.

Studying the Bible must be a rewarding and captivating experience. Family members need to learn and understand the will of God as presented in His Word. The more they are exposed to the Scriptures, the more they will absorb His revealed messages for them. Family worship time can become the special occasion for this journey of selfdiscovery of God's plan for each family worship participant.

The Bible is God's Word and it needs to be treated with love and respect. In the family worship setting, the Bible should be read and studied in such a way that its message reaches the hearts of each family member. This is a solemn part of the program but at the same time, it should be pleasurable. Some creativity must be used to make the reading and the studying of the Bible attractive and elemental in teaching moral and spiritual values. Following are examples to assist the family worship leader to achieve this goal: 
a) Make it practical - Bible text that applies to the specific situation $\&$ theme of FW (Seasons, nature, crisis, etc) that relate with the members' lives. (Psalm 104:10-27; Isaiah 1:18; Isaiah 55; Matthew 10:29-30; Philippians 4:13, 19).

b) Make it personal - Family members need to feel like "they were there," embody the personification of the Scriptures in their lives.

c) Make it relevant - Expand on the Bible's experiences, apply its relevant lessons in the members' lives, today.

d) Make it interesting - It needs to promote a sense of awe and respect for God, have a "creative reading" (i.e. divide portions, turns, allocate verses; personal understanding).

e) Make the reading attainable to children - It needs to be understood and appreciated by children. Promote inclusiveness, interest, and full participation.

f) Capitalize on spiritual lessons - Members ought to absorb the spiritual message and applications from its reading/study.

\section{Prayer - Communicating with God.}

In this modern age, communication plays a major role in the lives of human beings. Today, it is a nearly inconceivable idea to live without the advantages and services that are provided through the available channels of communication, like the internet, telephone (landline and cellular), satellite, TV, fax, etc. All of these were just a dream a few decades ago. People value these things as a means of contact with their loved ones and also as tools in their daily activities and businesses.

Prayer is an indispensable way for the children of God to develop and maintain a daily, continuous relationship with their Creator. It is also more important than all of 
those apparatuses for human communication. This is why prayer needs to be a sacred and all-consuming element of any worship activity. In the family worship setting, the prayers of the participants should aim to become the channel through which the family can be reached and touched by God as they worship Him. Prayer ought to be perceived as the channel that links the individual and family members to God.

Ellen White says that "Prayer is the most holy exercise of the soul." (EGW, Testimonies, 5:201). She adds that it, "does not bring God down to us, but brings us up to Him." (EGW, Steps to Christ, 93). In order to achieve this goal, creativity should be applied to develop an atmosphere in which prayer is seen as an occasion for the worshippers to dialogue with God and sense His presence amongst them. The worship leader is required to invest time in prayer, preparing the prayer activity for the family worship and aiming to involve all participants in this segment of the program. As the prayer pursuit is carried out during family worship, consideration should be given to children, so that this part becomes relevant and appealing to them as well.

There are different approaches that could be used to make prayer interesting, without losing its spiritual effect during family worship.

a) Prayer should have the feeling of touch - Humans are sensitive beings. God was the One Who implanted this feeling in the human heart. People like to touch and be touched as an expression of their feelings of love and affection. Such reality can be explored positively as the family prays together. One practice that continues to be attractive is to hold hands together in a circle when the family prays. This exercise allows the participants to feel and reverently touch one another, and at the same time "sense" the hand chain that links them to the Almighty hand of their God Whom they are 
worshipping. This symbolism promotes unity and is appealing to the members and especially the children, as it gives prayer the "visibility and feeling" of the touch of God.

b) Prayer ought to express the feelings of the heart - Humans are loquacious beings. God gave them this characteristic at creation (Genesis 1:27-28; 2:18-25). This ability to think and speak is one that differentiates humans from animals. Children learn to speak by observing their parents communicating with them and one another by words and also by actions. In this way, words and actions are utilized by individuals as a means that makes possible an interaction between two or more people, allowing their ideas, plans, and experiences to be shared and expressed.

In this context, prayer is the perfect exercise for humans to converse with God as they can entertain a close relationship with their Creator through the channel of prayer. The family worship activity should encourage people to develop such a practice by allowing them to utilize prayer as a way, "to open their hearts to God as to a friend."

Prayer should be simple but sincere and heartfelt, revealing confidence in God. An interesting manner to instill this feeling for prayer during family worship would be to allow the members to take turns as they pray. This could happen as each member prays short prayers one after the other (consecutive prayers) or as each says a phrase or two, expressing themselves in their own words. The latter format could be called continuous prayer because it only concludes when the last member has participated and then, at that time, everyone says 'Amen'.

c) Prayer needs to be spontaneous - A very important thing that should become practice during the family worship time is that spontaneous prayer is more effective than those which are memorized and simply repeated. This method appeals to participants to 
reach out to God in prayer as if they were talking to a close friend, which ultimately must be the goal of every prayer. This exercise should be encouraged among the family members and especially the children, as it will cause an impression of longing in their hearts to develop an intimate relationship with the Heavenly Father.

Alternatively, this method does not diminish the need to help and instruct the members, particularly the children, to memorize the Lord's Prayer. Special attention should be given to teach them to understand the meaning of this model prayer, so that it cannot become simply a "mechanical" repetition of words.

d) Be creative as you pray - There are different ways to pray. This means that the prayer experience can be a joyful and creative one. A family can stand or kneel, joining hands together when they are reciting the Lord's Prayer; they can kneel in a circle and start the prayer from the youngest to the oldest or reverse (consecutive or continuous prayers) either holding hands or with their hands on the Bible (exploring that touch feeling), or even embracing one another (closeness). Another way is to repeat the famous $23^{\text {rd }}$ Psalm as a prayer. Actually, this Psalm is considered the most well known Psalm of the Bible and it is usually the first one (often times the first Bible verses) children learn. In order to make it more effective and attractive, Psalm 23 and its meaning needs to be taught to the little ones.

e) Prayer should be a reverent part of the family worship activity - Adults and children ought to know that when they are praying, they are communicating with God. The sense of God's presence should inspire them to love Him and desire to enter into contact with their Creator. 
Each family should decide the position in which they pray to God, but whether it is kneeling, standing, or seated, depending on their specific situation and the condition of the room in which they are having their family worship, all members should be instructed to bow their heads and close their eyes when praying to God. This attitude not only avoids the interference of anything else that may distract them during the prayer time, but it also infuses in them a sense of respect and reverence for God. Prayer is a time for humans to speak with their God with the joy, and with the assurance of His interest in them and that He hears their prayer (2 Chronicles 6:39-40; 7:14; Jeremiah 29:13; James 4:10). It is also an occasion to present themselves in humility before their Maker, knowing that He knows everything about His creatures. All family members should treasure this moment of prayer with God.

f) Children need to be taught how to pray - It is of utmost importance that parents take time to teach their children to pray. The example is drawn from Jesus' disciples who asked the Master to teach them to pray (Luke 11:1). It is the parents' responsibility to teach their children to pray (EGW, Adventist Home, 317) and to come to God as their heavenly Father (EGW, Child Guidance, 480). Parents should also motivate their children to pray during family worship. Children's participation in prayer offers them a golden opportunity to strengthen their relationship with God, allowing them to perceive Him as being always present with them and also as Someone Who is close and interested in their well-being. This will also help to create in the innocent hearts of the children, a sense of enjoyment and respect for God as they grow and relate to Him as their friend. 
3. A Fulfilling Time of Praise.

Music is a gift from God. God's creatures were created with the talent for praise, and its original purpose was to be a blessing and to promote joy and peace in the human heart. Praising God is the tone of the heavenly courts where the angels sing and honor God for His goodness and mercy (EGW, Education, 161). Humans have the privilege of joining in singing and praising their Creator as one of the highest means to present God with an act of worship.

Family worship offers the perfect setting for this form of adoration to happen. In the quietness and comfort of the home, where the spirit is tender and soft, it is the ideal place for His Creatures to come into His presence with music, songs of praise, and a grateful heart. Below are some suggestions in order to achieve this goal.

a) Make the praise segment a time of spiritual uplift - The worship leader, in consultation with the other family members, should choose songs that are known and appreciated by the family. This will motivate all members to participate in this segment of family worship, creating a sense of involvement and interest in praising God. These songs ought to be spirit-filled, spiritually meaningful, and, "to inspire and elevate the soul" (EGW, Education, 167). Family members need to sense that their praise brings them closer to God and becomes a fascinating spiritual experience in their worship, as it exalts God's love and celebrates His mercy and goodness for His creatures.

b) Make the praise short and attractive - A certain time should be allocated for this part of family worship. In practicality, the best way to do it is to limit the number of songs that will be sung during the program. Then, choose the songs that address the 
needs of all participants. Choruses seem to be the best choice for an informal spiritual activity like family worship in the home setting, especially if the family has children.

A praise segment could start with a more lively song to catch the attention and participation of everyone and as the praise progresses it may consecutively wind down to a quieter and meditative song. Usually, the praise time should have between two to three songs for an ordinary family worship program. During the Sabbath vespers a little more time would be acceptable and encouraged for this part of the worship, as the family tends to be more relaxed and time should not be such a great concern as it usually is on the weekdays.

c) Make the praise time age appropriate - The praise segment in family worship needs to be age-appropriate for all family members and its planning needs to take into consideration songs that are appealing for the different age groups. This will promote an atmosphere of involvement for all members and create a sense of ownership among them as the family praises God through songs and music. In a family worship program where this matter is addressed, the praise time will tend to be interesting and fulfilling, leaving a positive impression in the hearts of the worshippers.

d) Make the praise a lively experience - The praise segment of family worship needs to be a lively experience inspiring the members in their daily relationship with God and one another. It should be one that promotes satisfaction in their hearts as they leave to deal with their human affairs outside their home. Ellen White says that singing praises to God, "is one of the most effective means of impressing the heart with spiritual truth.... The value of a song as a means of education should never be lost sight of." (EGW, Education, 168). A touch of creativity in singing the songs with actions will prove itself 
very effective in drawing the children's attention. Such practices will captivate them and entice their participation in the praise.

e) Use visuals during the praise time - One of the most effective ways of teaching and impressing a message, is through the use of visuals. People are not only attracted but also enthralled by what they see. The praise segment of family worship should include some sort of visuals related to the songs and music being sung that will catch the eyes and the imagination of the worshippers, promoting a stimulating environment for that activity, especially for the children. For those who have children in their families, it is rewarding and confirming to have a box with crafts of faces, animals, pictures of Jesus, angels, heaven, fruits, etc which the children reach into and cover their faces with, serving as a good illustration of what they are singing about. Here, like in the other parts of the family worship program, an investment of time is required, also money, and some creativity on the part of the parents as they prepare this family spiritual activity in a way that it becomes attractive and interesting for every participant, especially the children. As a follow up of this seminar a Parents' Family Worship workshop will assist parents to prepare some materials and illustrations for their family worship activity.

f) Utilize musical instruments or other sort of backing as you sing along - As much as possible and as these are available, musical instruments (piano, guitar, recorder, etc.) should be used during the praise time. If for any reason this is not possible, provide a $\mathrm{CD}$ or cassette player that can play a pre-recorded tape or $\mathrm{CD}$ with backing music as the family sings and praises God. If instruments are accessible and if the children can play, get them involved in playing for worship. The effectiveness and beauty of the praise 
activity is closely associated with the use of all the accessible talents and resources to honor God.

g) Allow the children to be in charge of the praise - In families with children, a good way to get them involved in the praise time of family worship is to let them (children) direct this part of the program from time to time. Assign one or all of them alternatively to plan and coordinate the singing, play the instruments, choose the songs, and to give it their flavor. Parents will be surprised with the creativity and talents that will be portrayed by their children.

\section{An Eye Catching Storytelling Experience}

This part of the family worship also deserves special attention and preparation. This segment should endeavor to discover and make practical applications by using daily examples from human history, nature, and especially from the lessons taught in the Bible through the experiences of God's people - His men and women of faith. Below is listed a series of ideas to assist families in organizing the storytelling time for the family worship.

a) Tell it as it really happened - People sense when someone is making up a story because their minds can identify fiction and fairytales. The storyteller needs to know the story very well and stick to the facts, expressing himself or herself in the most genuine and honest way. Using simple and direct words, he or she should introduce the historical setting, the situation, problems, challenges, and especially the results involved in the story as it really happened. The story should not be treated as a make-believe activity for the family. The storyteller needs to know that he or she is dealing with rational, intelligent, and perceptive people who appreciate honesty and sincerity. 
b) Make practical applications - The storyteller should draw practical lessons from the facts of the story that he or she is telling and apply them to the needs and challenges of his or her family today, rather than trying to create anything from his or her imagination. He or she ought to know that when the facts and realities of the story are presented, they confer credibility to the message it contains. The storyteller needs to study the story, trying his or her best to absorb the clear and also "hidden" treasures of the facts that will be presented. He or she also needs to have the ability to "discover" and apply the practical lessons in the lives of the family members. Each story has a moral and practical lesson. The storyteller should pray earnestly asking God for His wisdom as he or she prepares and presents the story. It becomes the storyteller's mission to bless the family through the application and appropriation of the story by the family.

c) Use the story time wisely - The storyteller needs to be precise and straight to the point, as he or she presents the story. He or she should make wise use of the allocated time for this activity, concentrating on the main points and the practical applications of the story. Little details, personal views, and things that are not mentioned in the story should be avoided. The storyteller needs to be able to "read the eyes" and sense the interest of his or her audience as they listen to the story. This part of family worship should leave a good feeling in the hearts of the family members and provoke them to think and reflect about what is being taught. Overdoing it will destroy the purpose of teaching a lesson to the family members.

d) Tell the story, do not read it - Generally speaking, people are turned off when they watch someone trying to tell them something by reading it to them. It becomes boring and it loses the interest of those who are being addressed. The storyteller ought to 
know the story by heart, and be captivating in the way he or she presents the subject. He or she needs to make it attractive by changing the tone of the voice while telling the story, acting properly to give the family worship participants the feeling of what really happened as the story unfolds, and by making use of appropriate illustrations to emphasize the main lessons. These will make the story appealing and pleasurable to listen to.

e) Use creativity - The storyteller should challenge the imagination of the family members by utilizing innovative methods to present the story. Although he or she is to stick to the facts of the story, some creativity could be used to introduce it in such a way that it becomes as original as possible. A good format for doing that is by dressing up like the Bible figure of the story, preparing some samples of the food described in the narrative, lighting candles to receive the Sabbath (Friday evening vespers), or utilizing figures and pictures for illustration. Parents should prepare materials that are ageappropriate for their children and which can be easily used by them to create indelible impressions in their minds.

f) Allow and support the children to tell the story occasionally - This method will get them more interested and involved in this part of the family spiritual program. This will instigate them to use their young imagination about the way the story happened and will help them to understand it in their "own language," giving them a sense of belonging and ownership of the family worship time. The whole family will enjoy lots of fun and receive deep spiritual insights from the innocent and pure minds of their children. 
5. Personal Testimonies.

These testimonies ought to be practical, tangible, short and drawn from the daily experiences of family members. This should be the time to thank God for the expected and unexpected situations, as well as the important and the simple things in life. These testimonies should include gratitude for things usually taken for granted, like their families, food, clothes, homes, jobs, and protection during their traveling. People grow in their experience with God when they learn to appreciate His blessings, even in little things usually accepted as normal occurrences in life. Family members should be encouraged to give their testimonies regarding answered prayer requests and provided with an opportunity to share Jesus with friends, work or class mates, and strangers. They should give thanks for promotions in the work place, success in their studies, and other special events in their lives.

6. Use the JDI Formula:

Family members need to realize that they can improve their family worship experience as long as they make it a habit. This JDI formula simply means, "Just Do It!" 


\title{
“OUR FAMILIES FOR GOD” FAMILY WORSHIP SEMINAR
}

\section{Third Section}

\author{
“The 'How' of Family Worship"
}

In section II we discussed the "Characteristics and Elements of Family Worship." Since we have established the relevancy of those aspects, it is time for us to discover the "Benefits of Family Worship" and to bring suggestions about the family worship program itself, as well as special ideas for the family worship leader at home.

\section{Part I - The Benefits of Family Worship}

It is important that we realize the benefits that such activity shall bring to our families. Family worship needs to be perceived by the family as a spiritual gathering for them to gain blessings from their God, who is their Creator and Sustainer.

The benefits of family worship can be listed as:

a) Family worship promotes unity in the family. This spiritual activity provides the family with an occasion to meet and spend time together. There, they share the blessings and concerns of their lives, enjoy their relationship with one another and all of them with God. These will help them to develop a sense of spiritual coherence.

"Family worship has been like a rudder in a restless and confused world. It's tied our family together in a meaningful way. And we'd highly recommend it is a special way to bind your family together, too, for now and for eternity." (Kay Kuzma, "Family Worship Binding your Family Together for Now and Eternity," Redlands, CA: The Quiet Hour, 199-). 
b) It reminds the family about their dependence on God. Family worship helps the members to remain in tune with God, realizing that they are His creatures and that they are dependent on His protection and love. Ellen White writes about this topic.

"Let the members of every family bear in mind that they are closely allied to heaven. The Lord has a special interest in the families of His children here below. Angels offer the smoke of the fragrant incense for the praying saints.... Morning and evening the heavenly universe takes notice of every praying household." (EGW, MS 19, 1900).

c) Family worship brings to the family a consciousness of their spiritual life. This activity assists the family to grow in their desire to experience a closer relationship with God. It also makes them stronger in their spiritual lives and aware of God's power to help them to be victorious in their daily struggles.

"So the homes of the Christians should be lights in the world. From them, morning and evening, prayer should ascend to God as sweet incense. And as the morning dew, His mercies and blessings will descend upon the supplicants." (EGW, Testimonies, $7: 44)$.

d) It invites heavenly beings to join the family in adoration to God. Family worship provides the atmosphere in which angels take pleasure in being present in a place where serving God is the primary interest of the family.

"When our homes are permeated with prayer we invite heavenly guests. Angels love to linger in such homes, and the peace, comfort, and protection they bring is beyond estimation." (Beatrice Wornow, "Building Altars," Review and Herald, 24 May 1956).

Our little summary then reads:

a) Family worship promotes unity in the family.

b) It reminds the family about their dependence of God.

c) Family worship brings consciousness to the family about their spiritual life.

d) It invites heavenly beings to join the family in adoration to God. 


\section{Part II - Suggestions for the Family Worship Program}

In preparing an attractive and relevant family worship activity for the family, one needs to realize that there are some important elements which will determine the success of the program for the family and these need to be considered and carefully prepared.

1. Balance the elements of content and length of the program.

Regarding the "content" it is vital to remember some important factors:

a) Failing to plan is already planning to fail. In order for the content to be attractive and relevant, the worship leader needs to invest time in planning the program.

b) Make the content relevant, lively, interesting, age appropriate, and above all, spiritual. The program needs to cater for the spiritual growth of the family.

c) Use adequate resources to make it attractive without sacrificing the spirituality. This can involve the use of multimedia, musical instruments, crafts and props, etc.

d) Use creativity. Design the program to make it interesting and engrossing. A dose of creativity can make the family worship content relevant and attractive.

One needs to consider the length of the program very carefully. It will have an effect on all participants.

a) Be realistic about the family composition. Consider the composition of your family. Adults have a longer attention span than children.

b) Make it suitable for family members' schedules. Family members may have different study and work plans. The length of the program needs to be considered in relation to this factor.

c) Have a consistent plan. Discuss this issue with your family members and be consistent regarding the length of your family worship program. i.e. 10-15 minutes. 
Another important thing to consider regarding the content and length of the program is that the contents are related to the relevancy of the program and length to the level of attention and interest that the activity will generate.

2. Time Element.

There needs to be consistency about the time for the family worship program. Again, this time element (either in the morning or evening or both) will be also determined by the composition of the family and the schedules of family members.

The following suggestions could be applied in organizing family worship:

a) Before or after breakfast or even at the breakfast table with your children.

b) At night - more relaxed, before going to sleep or taking your children to bed.

c) The most appropriate time will be whenever most family members are present.

d) Create a habit of having family worship in the morning and in the evening.

\section{Frequency of Family Worship.}

As much as our bodies need food to survive, our souls also require the strength and comfort that only communion with God can provide.

Family worship needs to be recurring. This should be arranged in each family. The suggestions are:

a) Family worship should be conducted daily and regularly.

b) Because our homes are also our little sanctuaries, family worship ought to follow the pattern of the earthly sanctuary, morning and evening.

c) Family worship needs to be part of the family daily schedule.

d) It should take place besides each individual's personal devotions. 
There is a close relationship between the practices of personal devotion and family worship. "If you don't have personal devotions, forget family worship." (Youngberg, Heart Tuning - A Guide to Better Family Worship, 62). Personal devotion should reflect our private intimacy with God, while family worship shows the family's desire in continuing to have God as the One Who links the members as they worship Him together.

4. Place for the Family Worship Activity.

Each family should choose carefully the best place for them to practice their family spiritual activity in their own setting. The ideal is that the place be a common area of the house where all members can feel comfortable. Such places can be:

a) Breakfast table.

b) Living room or family room.

c) For those with children it could be the parents' or children's bedrooms.

d) The best place would be to set aside a family worship area or room. This would create a sense of reverence for the activity and as well, all the spiritual materials used for the family worship activity could be stored in that place. This would require a bit of space in the house, but it would be worthwhile in the end.

\section{Order of the Program.}

Family worship needs to follow some sort of structure and organization in order to achieve its purpose, which is to worship God. As mentioned before, we serve a Father of love and a God of order. Suggestions are offered below which would make this activity attractive and relevant. 
1. Praise - The first part should be the praise segment. It should be uplifting as it will prepare the hearts of the family members to be in tune with the spirit of the program and to hear God's voice through prayer and the reading of His Word. Sing 2-3 songs, choruses or hymns. Start with a lively one and then one or two more, but by the time the last one is sung it should be a melodious and meditative song. Use some musical instruments (flute, guitar, piano, etc) and/or multimedia. The songs should be age appropriate. The idea is to assign a family member to be the praise leader. This arrangement can be made for each day or week (best).

2. Prayer - Immediately after the praise, someone needs to pray. The prayer should be assigned to another family member (remember the children), if someone else has already played the instrument. In the morning family worship, the prayer ought to thank God for the meal provided for the family and it also needs to include the family's gratitude to the heavenly Father for the privilege of praising and worshipping Him. It should thank Him for the restful sleep and His protection during the night. It is worth teaching the family (especially children) to thank God for what they have enjoyed. It helps to create in them a sense of gratitude and recognition. This should be a short and heartfelt prayer, leading the whole family to sense the presence of God among them and be thankful to Him.

In the evening, it should happen in the same way. Thank God for His blessings and protection during the day, safe arrival at home, work, studies, dinner, family unity, the privilege to freely worship Him, etc. This prayer needs to express the family's feelings of joy as they come together to worship their Creator and Lord. 
3. Bible reading and study or story time - Here, the order can be rearranged to accommodate the reality of each family. However, it is imperative to make the distinction between the reading and study of the Bible, and story time. The story can be told from any other good book of moral stories. These stories are important and have their values, but they cannot substitute for the Word of God.

Appropriate, relevant, and creative illustrations can be presented during the story time. The suggestion would be to have the story time first, as it tends to be told in a more relaxed atmosphere and then have the Bible reading or study. Another idea would be to sing a short song at the conclusion of the story time. If this is the case, this song should connect with the main point of the story. This story could be the Sabbath school lesson for the children.

The important facts here are: Tell the story, do not read it. Make it attractive with some form of illustrations or visual aids and be creative. Make the members, especially the children, feel that they are part of the story and are involved in it. Occasionally, take the time to instruct and teach the children to conduct this part. This certainly will be more effective during the evening program, because of the reasons already mentioned.

The evening segment of the story time can be more relaxed and impressive. That would probably be the best time to get the children involved in leading and telling the story. Have some extra objects available to illustrate the story. Things like dressing-up, food, stones, candles (be careful in allowing the children to handle them), will make it seem real and interesting. Let the family members go to bed (or in some cases to work) with a vivid memory of what the story has informed them about. 
4. Bible reading or study - This is probably the most solemn part of the family worship. The way the Bible is handled, read, or studied ought to create a powerful impact in the hearts of the family members. It should inspire reverence. Select the applicable portion of Scripture with much prayer, so that it might make a clear and visible connection with the overall theme of the family worship. Emphasize the lesson it teaches but remember to let the Scriptures speak for themselves.

Also, be mindful to use a translation that is suitable for everyone present and make room for the Spirit of God to speak to the hearts of the family members. In the morning this part can be a simple and special verse or text. Another idea, especially for those with small children, will be to teach them to memorize small verses from the Scriptures, to be recited during this time. This will give them the occasion to familiarize themselves with the Bible and its promises, helping them to grow in their confidence and relationship with God. Whoever reads or recites the Bible verse or text should do it aloud and with good intonation in his or her voice and should not act in haste.

In the evening, the flexibility of time allows this part to be performed with some special preparations. The worship leader should ask someone to prepare ahead of time the reading of the Scriptures and to explain the importance of the text in their own words, as well as the lessons it taught them.

A better situation will be to prepare a study of the subject presented in the text, showing the context and the primary focus of the Bible writer regarding that text or passage and making the applications for the family, today. This part will require one of the parents or an adult member of the family. It should be short but interesting. If the family has children, make it attractive for them by telling the story behind the text 
(children usually like stories) and highlight God's protection and His plans for His people. Also, as the passage is read, include the children in the story by identifying the characters and situations, comparing them with their own. For example, in the story of David and Goliath, the younger member of the family can be David and a mature member Goliath, or Goliath representing the difficult problems people face in their lives; the older brother being Elijah, the younger Elisha; the use of typical Bible time clothes; family pets to represent the animals described in the text (Noah's ark, a bird as Elijah's ravens); father and mother as the kings and queens of the text (or even some of the children - prepare some crowns); some toy instruments to be played by the family at the coronation of the kings, Jesus' entrance in the heavenly courts (Psalm 22), etc.

Lots of creativity could be used to help the family, especially the children, to make associations with the Bible text or passage in an orderly and reverent way, nevertheless interesting.

5. Personal Testimonies. - This part could follow the Bible reading or study and needs to be concise and practical. All family members need to be encouraged to express themselves freely, and provision should be made for everyone to have the opportunity to speak. One idea is to split this segment in two, between the morning and evening programs, so that time pressure can be alleviated. Motivate the family members, including the younger ones, to see and speak about something positive in their family, home, school, teachers, friends, nature, etc that inspires them to be thankful. Challenge them to make direct applications to the situations in their own lives. Make this an inspiring, praise-worthy, and time full of gratitude for the whole family. Use creativity to 
encourage the members to speak. The more the family acknowledges their blessings, the happier it will become.

6. Final Prayer \& Benediction - This prayer concludes the program. It should be a short and direct prayer. It can be done in random order, (with each member taking his or her turn during the family worship programs - have a list not to compel, but remind), consecutively (one praying after the other) or continuously (everyone has a turn with short phrases, sentences, until the last one prays and all say 'amen') as explained before. Another way is for the whole family to recite the Lord's Prayer or even use Psalm 23 as a prayer from time to time. During this time, as shown before, the family members can join hands together as they stand or kneel in circle, embrace one another, touch each other's shoulders, etc. The point here is to have the physical contact as this prayer is sensed, as they are communicating with and touching their heavenly Father, either to ask His protection during the day (morning) or thank Him for His blessings as they request His presence and company during the night (evening).

The whole program should last between $10-15$ minutes in the morning and 15 20 minutes in the evening. Below is the suggested schedule time for each part.

Morning

Praise: $2-3$ minutes

Prayer: $0.5-1$ minute

Story: $2-3$ minutes

Bible reading \& study: $3-5$ minutes

Testimonies: $1-2$ minutes

Final prayer: 1 minute
Evening

$3-5$ minutes

$0.5-1$ minute

5 minutes

6 minutes

$1-2$ minutes

1 minute 
The order of program and scheduled time presented above can vary periodically. The family worship activity does not need to follow the same structure always, otherwise it leaves no room for creativity. The worship leader needs to be wise and sensible to design a program that suits every member, at the same time ensuring it is mixed and attractive.

Suggestions for the Sabbath Family Worship Program

The Sabbath family worship should be the most interesting of the week. The program should be designed in such a way that it creates a sense of expectation in the hearts of the family members, so that they look forward to it. Each part needs to be carefully prepared and given a special touch, as this activity marks the beginning and closing of the Lord's Day, and at the same time it prepares the family to meet with their extended family members, God's people, in His Sanctuary on Sabbath.

Every part and detail of the program needs to highlight the special fellowship that the family should enjoy with God during His holy day. Over and above the suggestions given for the weekday family worships, below are listed some ideas on how to make this Sabbath opening and closing a rich, pleasurable, and unforgettable experience for the whole family.

1 - The preparation for opening the Sabbath involves the spiritual and physical readiness for the occasion. Everything should be arranged in a distinctive way to promote the spirit of adoration. The house should be clean and possibly adorned with some fresh flowers, beds made, the food ready, and the family members bathed to receive the Lord's gift, His holy Sabbath during their family worship. 
2 - A special food should be cooked for Sabbath dinner. Celebrating a meal together in the Bible was a symbol of a covenant between people, and the people and God (Genesis 18:1-15; 31:51-55; Exodus 12:1-13; Leviticus 6:15-16; 25-26; 7:15-16; Luke 22:14-16; Revelation 19:7, etc). This Sabbath family worship should also celebrate the event of the Lord's Sabbath provision for His people (Mark 2:27-28). This is the best time to use the family's best plates, cutlery, and glasses. This is a time of rejoicing for the whole family.

3 - Make it a celebration. Light some candles to welcome the Sabbath during family worship. Be cautious as children handle the candles and light them. Use creativity and good taste. Do not be pressured by time. Allow the family members to sing, talk, and enjoy this very special moment. Another week has gone and the family is now one more week closer to the day of meeting their Savior! Personal testimonies should be encouraged and the singing of inspiring songs. Make sure some sort of musical instrument or background music ( $\mathrm{CD}$, tape) is used to enhance the praise that is offered to God.

4 - This is the best time to use creativity and extra resources which for any reason could not be utilized during the week. Organize a skit or play with some Bible costumes or even some Bible games for the family. Make some Bible food samples and share the meaning of those foods, as they relate with to a Bible story. Let the atmosphere be relaxed and one that invites praise and gratitude in the family as they exalt God's goodness in worship. 
5 - Allow the children to be involved. Let them periodically organize a special part or be in charge of the singing, story or even the program. Make them feel that they are important and have something to offer to the family.

6 - Make it the highlight of the week. Summarize the blessings of the week, even those that people usually take for granted (food, shelter, family, the freedom to worship God, etc) and allow the family members to relate these to their own experience. Make it pleasant, providing an opportunity for them to express themselves.

7 - Remind the family about the joy of worshipping God together with all believers at church on the Sabbath day. Make them long for that occasion on the following day. Let the family members go to bed thinking and designing plans to fellowship with their brothers and sisters in Christ. Promote the corporate worship of God during your family worship.

8 - Many believers close the Sabbath together at church. This happens as they are involved in the activities of the church during the Sabbath hours and are still in church at sunset time. This vespers program is relevant, but it should not take the place of the privileged occasion in which the family conducts closing Sabbath together. The church calendar should be arranged in such a way that it provides liberty for members to go back home and conclude the Sabbath day within their own circle. Talk to your pastor in this regard.

9 - During the Sabbath evening vespers, recite a Psalm, sing, talk about the blessings received at church, the fellowship with other believers, and remind and briefly discuss with the family members about the main topic of the sermon. This should probably be the most informal and relaxed of all family worship programs of the week. 
10 - Have a commitment time during the Sabbath evening vespers. Encourage the family members to make professional (or study) and mainly spiritual goals in their lives for the new week. Create an environment of satisfaction for the finished week and at the same time sadness because the Sabbath is ending. Help them to start longing for the next Sabbath day, as they close each Sabbath.

11 - Consider inviting someone home (relative, friend, church member, etc) either to open or close the Sabbath with your family. Try to do this with someone you and your family are praying for. Share the blessing of this moment with a missionary vision.

12 - Gather all family members for a special prayer as you begin the new week together, as a family.

General Suggestions for Parents or Worship Leaders

1 - Set a time or times (morning and evening) for family worship. Do this in consultation with all family members. This agreement will help them to schedule and organize themselves for this spiritual activity. This will enhance the importance of this family program.

2 - Get all family members to commit to and honor those times for this spiritual activity. As much as possible, create a situation which avoids external interference during family worship. Leave the answering machine on or even disconnect the phone. The family needs to feel that this is their time to worship God and fellowship with one another.

3 - Choose a place in the house where the program will take place. It will assist the younger children to associate that space or room with family worship. 
4 - Create an atmosphere of joy and excitement for the time (times) of family worship. Let God's Spirit dwell in and inspire every heart as they come to worship Him.

5 - Organize the program and its parts beforehand but also remember to allow the Holy Spirit the opportunity to inspire with the necessary adjustments as the program moves along. This preparation will help the program to run smoothly and will convey the importance of family worship to the whole family.

6 - Try to get every family member involved in doing something or taking responsibility during family worship.

7 - Allow the children to plan and/or direct a family worship program from time to time. Make them feel that their input and ideas are valid and important for the family.

8 - Be creative as you prepare the program. Ask the Lord to bless you with new ideas and creativity, illustrations, and special music.

9 - Be sensitive to each age group as you prepare the family worship program.

10 - Do your best, God does the rest. He will reward your efforts (2 Chro 15:7).

\section{Part III - Family Worship as a Potential Evangelistic Tool}

The goal of every Christian activity or program should be to win souls for Jesus Christ through the means of preaching His Gospel and also by creating a positive influence in other people's lives. In this context, the family worship activity can also be utilized and converted into a potential evangelistic tool for the family in reaching such objectives in its dealings with relatives, friends, and neighbors.

This part will focus on suggesting friendly, caring, and creative ways and ideas for introducing family worship to those associated with the ordinary family. 
Live Your Religion

The best way for anyone to witness for the Lord is still to live the principles of his or her beliefs at home. The true colors of one's character are revealed in the family setting. The family members can see the reality in their loved ones' lives because they all live under the same roof. This family worship ministry or witnessing also starts at home. Every family member should live their lives in harmony with the principles they talk about. This is especially true for parents. They should set a good example for their children, as they easily perceive phony attitudes and dual characters and lives.

Family worship will create a positive impact in the children's lives if their parents live their religion according to their profession of faith, with each other, with their children, and also in their daily business dealings with others. As a result, the children will remember with delight their family worship time, even during the later years of their lives.

The family's relatives also perceive the sincerity of the words and actions of their loved ones who profess a religion or a different faith to theirs. This silent witnessing is crucial, but there are other things that the Christian family can do to share their beliefs. Family worship is one way through which they can reveal their faith. Family members should not miss the opportunity to communicate with their relatives, the blessings they have received through their family spiritual activity. Some ideas are listed below:

Pray for the Sick

If any of their relatives are sick, the Christian family should let them know that they are praying for the sick person in their family worship. The means of a card could be used to state their prayers and wishes for recovery of the sick. During their time of 
sickness, people usually tend to have their hearts softened to listen to spiritual matters. A sincere and honest prayer will prove itself very effective for them (James 5:16).

\section{Capitalize on Special Occasions}

Occasions such as birthdays, wedding anniversaries, school graduation, a new job, retirement, etc, in the life of a relative, provide excellent opportunities for the family to express their attention and recognition for their achievements. These could be good occurrences for offering prayers for them during family worship. Perhaps a card or a phone call stating that the family is praying for the relative involved, could show their interest in his or her well-being. Alternatively, the family should consider inviting the person (and his or her family) to join them for a special family worship that celebrates that specific occasion.

Different methods could be used to reveal to their relative (s) how much the family is enthusiastic about their accomplishments. People are usually touched by gestures of appreciation shown to them during memorable moments in their lives.

Be Genuine

As a rule, genuineness impresses people. The family members need to show their true feelings of love and of heartfelt spiritual concern towards those with whom they are acquainted. Through the means of kind Christian attitudes they can create a motivation for people to enquire about their religion. Their words and actions ought to reveal their practical Christianity to their relatives in a way that generates an interest in the message.

A family which resembles the character of Jesus Christ in their lives and dealings with people has a convincing way of attracting their relatives to their faith. This will 
cause their extended families (relatives) with non-Christian or different belief backgrounds to be interested to know about their believing relatives' religion and its activities that make them caring and friendly people. This will be the chance for the believing family to introduce their family worship activities to their relatives as a program where the relatives' families are also considered and prayed for.

\section{Part IV - Live Your Religion with your Neighbors}

The suggestions presented in the last section also apply to the way family worship can become an evangelistic tool for reaching out to the neighbors. It is true to say that good neighbors sometimes are closer than relatives. The reality is that the neighbors are always nearby and the tendency to have a form of interaction with them is greater than with relatives living far away. The fact is that neighbors live in the same street or building and children (theirs and yours) are usually quick to establish some contact amongst them. All of these factors cause neighbors to have some sort of association with one another. In this scenario, the believing family can share their faith in creative ways, including designing their family worship to attract and involve their neighbors.

Get the Attention of your Neighbors

1 - One of the most effective methods to reach the hearts of neighboring parents will be by treating their children kindly. From the moment you perceive that your children are associating with other children, when they first meet at the neighborhood playground, or during swimming lessons, or even by simply playing on the street, treat them with attention, showing a genuine interest in that friendship. Parents are warned not 
to overdo it because people are usually very suspicious about their children talking to strangers, even neighbors.

2 - Let your children do their part in being considerate and friendly to your neighbors' children, which will certainly catch their parents' attention.

3 - When time permits, introduce yourself gently and entertain an informal conversation saying that you have noticed that their children and yours enjoy playing together, have become good friends, etc. Remember to leave your neighbor at ease. Be kind, genuine, and offer your disinterested service.

4 - Another appropriate way will be to invite their children to your children's birthdays, graduation, or any other special occasion. This will create a bridge for establishing a closer relationship.

5 - Their children will notice that you and your family say grace before eating food, or pray for the other reason of the gathering. Explain succinctly about your practice of thanking God through prayer and let them understand the importance of that moment. Include them and their family in your prayer.

6 - When that relationship becomes closer and you have discovered the neighbors' and their children's birthdays, send them a card signed by all members of your family and state that you and your family will be praying for them in your family worship at home that day. Do not miss this golden opportunity for sharing your faith and telling them about the secret of happiness in your home - your family worship activity with your family members. 
7 - Pray that God will give you a chance to invite your neighbor over to your place for a special family worship in which you will be able to pray and reveal your faith to them.

Greet the New Neighbors with your Heart

1 - Whenever you notice that a new family has moved to your neighborhood, as soon as an opportunity presents itself available, introduce yourself and offer your genuine help if they need any assistance in their new location.

2 - The best idea will be to take a fruit basket or some flowers with a "welcome to our neighborhood" card with you, just to materialize your visit to their door step. Write on the card your wishes that they enjoy and be happy in their new home and that you and your family will be praying for them during your family worship. This gesture will be a great start to a relationship in the future that should allow you to share Jesus with them.

3 - The same idea of praying for your neighbors during their sickness, as was suggested you do with your relatives, will also cause a positive impact in your relationship with them.

4 - Follow the same line of thinking and acting as they celebrate special events in their lives, just as you do with your relatives. Make the bridge of your family worship an activity by which your family shows love, interest, and spiritual concern for your neighbors.

5 - Do not be afraid to talk with them about your family worship achievements.

6 - Above all, pray that God will open the doors of opportunities for you and your family to witness for Him in your neighborhood, utilizing all possible means to share the joy and certainty of your salvation in Jesus. 
7 - Remember that the heavenly Father is a God of all peoples and He will grant your request to make a difference in other people's lives, especially your neighbors. The resource of family worship can be just the beginning of a way to convey your faith to your neighbors.

Thanks for your participation.

See you in the last section of the seminar. 
“OUR FAMILIES FOR GOD” FAMILY WORSHIP SEMINAR

\author{
Fourth Section
}

Worshipping God with Children

This section will highlight the utmost importance of introducing children to God. Family worship could be the golden opportunity for parents to begin a life-long relationship and experience between their children and God. This segment of the seminar will present the "When" and "Where" of family worship, as well as specific suggestions for making this spiritual activity a delight and a pleasure for children.

\title{
Part I - The "When" of Family Worship
}

Ellen White penned these inspired words:

"In childhood the mind is readily impressed and molded, and it is then that boys and girls should be taught to love and honor God." (EGW, Adventist Home, 486). This statement makes clear the fact that every child should be taught and led to love God in the first years of their lives. From this statement one can draw an important conclusion:

1. Parents are responsible for teaching their children about God.

Again, Ellen White writes:

"Parents are to realize that they are responsible before God for making their children acquainted with their heavenly Father." (Review and Herald, June 6, 1899). 
In order to achieve this spiritual goal:

a) Parents should teach their children by example - Children learn what they see. Their parents' lives teach them about God's love and character. Parents should teach and live their words. There is no place for, "Do what I say but not what I do."

b) Parents ought to pray for and with their children - Prayer is powerful! Parents need to show their children in a practical way that heaven is interested in their well-being.

c) Parents must remember that they need to spend quality time with their children. They should have fun with their children, enjoy them while they are still at home, show that they care about their children, and engage in a daily, practical, and relevant religion with them.

d) Parents have to make religion a priority in their home - Fame and money turn to dust but eternity with God = real gain. Parents need to concentrate on the results of their family tree. (Story of the lives of J. Edwards and Max Jukes).

2. Parents should make religion attractive for their children.

There are some relevant elements that parents ought to know in order to achieve the goal of making religion attractive for their families, and ultimately to their children:

a) Help them to be grateful - Count their blessings at home with their children, talk about positive things, instill the realization of God's care in their lives.

b) Instruct the children to take nothing for granted - Food, shelter, family, freedom, and the knowledge of God are usually accepted as part of one's life. Parents need to teach their children that all of these come from God. Also, they should show children God's protection in their lives, through these blessings. 
c) Invest time in preparing the family worship activity - They ought to be creative, preparing a variety of activities and materials (Family Worship Treasure box); as well as organizing special occasions for their family worship.

d) Be accommodating and age-appropriate when preparing for family worship at home - Design the program to address their children's needs and consider their age in the activities of the program.

e) Involve their children in the preparation of and participation in family worship activity. This will give the children a sense of ownership and it will bring excitement to them. Parents need to think and try to become like a child when making arrangements for their children in family worship.

3. Parents ought to introduce their children to Christ.

The best way to achieve this goal is to show Christ's love through their dealings with their children. Parents must know that the image that their children will have of God, is the one that they show to them daily. Some suggestions are offered below:

a) Show them that Jesus is their Savior - Children need to be taught that Jesus died for them, He loves and cares for them and is their best friend.

b) Assure them that Jesus hears their prayers - Teach children to pray with confidence and motivate them to approach God's throne of grace. Pray for them and with them.

c) Advise them that Jesus is their best friend - Promote a close, intimate, and personal relationship with Jesus. He is always there for them! The best manner in which to exemplify this is by parents being always there for their children themselves. 
d) Use simple and direct language - Adapt the salvation message to their children's language level. Use appropriate illustrations and comparisons that bring the Gospel message to their hearts. Parents do not have to preach, but live the message and their children will follow them.

e) Be consistent and have a regular time for family worship - a defined and daily plan for the children to meet Jesus at the "Family Altar." Parents should not confuse their children by skipping family worship when they seem to be too busy. It is better to have a simple family worship than none.

\section{Part II - The "Where" of Family Worship}

Parents need to realize that their children are very conscious of the space of their house. They act like that because since their birth or when they moved to that place they have been exploring the rooms and every little corner of their residence. This also creates a need for parents to create a space for their family worship activity. Simple ideas can address this issue.

1. Establish a regular place in the house for family worship.

a) Choose a common area of the house - it can be the breakfast table (morning), living room or family room. Be mindful of the fact that children need and enjoy space. Leave them in their comfort zone to enjoy all the activities and props that parents should have prepared for this family spiritual occasion.

b) Children's and/or parent's bedroom for the evening program. Not so much time pressure and it is more relaxed. These rooms are appealing, with friendly environments for the children. They certainly not only enjoy their own bedrooms - they also like to come and sneak around their parents' bedroom. 
c) Encourage a family worship area or room at home. The best place would be a room specially designed and reserved for this family spiritual activity, if possible. It will create a sense of reverence and consistency in a proper environment, and as well, all family worship materials can be stored there. It requires extra space in the house but it will prove to be an excellent investment.

2. Parents should be conscious that children enjoy change and surprises.

Adults are very resistant to change. It happens to be completely the opposite with children. They enjoy and even "cry" for some changes and things out of the ordinary. The ideas below can probably address this matter.

a) Be creative - Parents need to use their imagination, such as when they were a child. They should think about a different place for family worship once in a while. Maybe an outdoor family worship, a picnic family worship, a garage family worship where parents can use and explain the function of some tools and compare them to God's love and power.

b) Celebrate special occasions - Parents can plan for a special family worship at the Sabbath dinner table (sunset) or Sabbath afternoon nature walk family worship to learn about God's creation. Another idea would be to have family worship in a family member's room if they are celebrating their birthday, graduation, and/or any other important date in their lives. Creativity ought to be the magical word for these special celebrations.

c) Parents can always surprise their children - They could decorate their children's bedroom for a special or surprise family worship for their birthday and/or graduation. Make it a "Thanksgiving Family Worship." They can also capitalize in 
celebrating other Christian occasions with a special family worship celebration (New Year, Easter, Christmas, etc).

\section{Part III - Illustration in Family Worship}

Illustration makes the main topic or subject being presented or discussed more meaningful and practical. In the same way, appropriate illustrations should be used as an incentive during family worship time. This method can positively affect the whole program, making its message attractive and understandable to the family. Some suggestions are presented below:

1. An illustration is worth a thousand words.

a) Use simple illustrations from life and nature. One of the reasons Jesus was very successful in His ministry and in His speeches was the fact that He utilized the illustrations from day to day living and from nature when He was addressing the crowds. This approach is easily grasped by people, especially children. Ellen White says that, "by illustrations best suited to the child's comprehension, parents and teachers may begin very early to fulfill the Lord's injunction concerning His precepts ..." (EGW, Education, 185). These illustrations could be used during the story, praise, prayer or Bible reading times. The illustrations should not be another segment of the program itself, but contribute to each of the major parts of the family worship activity.

b) Make them real and interesting - The effect of a fitting illustration can be lasting and impressive. The lessons and illustrations taught in daily family worship should be objective, straight to the point, and easy to be grasped by all members. The reasons for this are the time factor, especially during the week, and also the difficulty for the children to understand a subjective lesson without proper instruction. Subjective 
lessons requiring time for teaching and discussions might be a good exercise for Sabbath opening and closing family worships, when the family is usually not so hard-pressed for time.

c) The illustrations must be practical. Practical illustrations will gain the attention of the people, bringing its messages to their hearts. When the illustrations are made practical, in whichever part of family worship, they will be appealing and easily applicable in people's lives. The example of nature (flowers, birds, other animals, seasons, etc.), as utilized by Jesus, linking the creatures' needs with the Heavenly Father's knowledge and care (Matthew 6:26-33; 10:29-30), also the situation where His followers are challenged to be innocent and pure as children (Matthew 18:1-10; Luke 18:15-17), "red" sins confessed and made white as snow (Isaiah 1:18) are very powerful. The goal of a practical illustration is to enable family members to establish the immediate connection between the topic and the illustration.

d) Make them age appropriate - The illustrations need to be appealing and made applicable to each age group. The practicality of the illustrations will be measured by their interest and level of involvement for all family members. Whenever the Bible is read, a story is told, a praise song is sung, and even a prayer is offered, the illustration associated with that part needs to be age appropriate. In a family worship where just the needs of the adults or children are cared for, it tends to become disinteresting for the group that is left out. The illustration needs to be naturally understood and applied in the lives of the hearers.

e) Prepare visual illustrations - It is adequate to draw parallels from illustrations presented in stories, nature, etc, but the effectiveness of the illustrations will increase as 
they are made concrete and visible. That is why it is important to endeavor to have visual illustrations during the different parts of family worship. This is where the "Family Worship Treasure" box (that can be designed by parents) with crafted animal faces, trees, flowers, fruits, angels, pictures of families, Jesus, toy musical instruments, illustrative stories, Biblical clothes, etc plays a major role in this spiritual activity for the family, especially for the little ones. These visual illustrations can be made at home, which will give them a special and personal touch, or bought from department stores. If the parents decide to make these visual illustrations at home, it would be a good idea to involve their children as they prepare these items for family worship. This will enhance the children's interest in the visual illustrations, as well as give them a sense of ownership in the program. The concept taught through this procedure is that the illustrations should be made real, visual, appealing, and inclusive.

2. The Bible is a visual Book.

a) Every time God made a covenant with His people, He introduced a visual illustration sealing it with an action that was usually in the form of a dramatization of the terms of the agreement (Marvin Wilson, Our Father Abraham, 306). Examples can be taken from the Old Testament covenants with Abram (Genesis 15:7-10), the circumcision (Genesis 17:5-13), the Passover (Exodus 12:1-13), the giving of the Ten Commandments (Exodus 19-20), the pillar of fire and cloud in the desert (Exodus 13:21), and also through the experience of Hosea and Gomer, as described in the book of Hosea, etc.

Visual aids are also found in the New Testament. Jesus instructed His disciples about humility by bringing a little child among them (Mark 9:36) and by washing His disciples feet (John 13). Also, Jesus used a coin to teach His followers about their duty to 
pay taxes (Luke 20:20-26). Paul made the visual connection between the believer's baptism and the burial and resurrection of Jesus. The Bible portrays God's love visually.

b) Parents should pray about their illustrations. Each worship leader should ask God to inspire him or her in preparing the different parts of the family worship so that it might be spiritually appealing and full of life. Illustrating the segments of this spiritual activity for the family is like making it comprehensible, touchable, and practical. The family worship leader should pray about the illustrations, search for the best applicable ones and ensure they are in harmony with the theme being studied. Ellen White says clearly that family worship requires "careful preparation" (EGW, Child Guidance, 521) in order to make it enjoyable and attractive.

c) Parents need to prepare their own visual illustrations - A well prepared family worship in which parents invest time in creatively designing a "Family Worship Treasure" box for their children, as well as getting their children involved in its preparation, will pay itself off. This will give parents the satisfaction of using their time for something positive and above all, of spiritual benefit for their families. They will also notice the level of interest, involvement, and sense of ownership of their children in regards to this family worship activity. Parents could also use multimedia resources to enhance the atmosphere of the program. They also need to especially design surprises for their children.

\section{Part IV - The Ten Commandments of Family Worship}

In concluding this seminar, it will be appropriate to highlight the importance and sacredness of family worship as the spiritual and fellowship activity for the family. The best way to impress this message is by paraphrasing God's most sacred words and 
instructions to His children with the privilege and duty of every parent to conduct family worship in their home and especially for their children.

1 - You shall have no other more important occasion at home than the family worship time.

2 - You shall make no excuses for bowing down every day before your TV, computer, internet, or video-games. Although most of these are good things if properly used, they shall not compete with your family worship time in your household.

3 - You shall not misuse the family worship time by replacing it with anything else, for the Lord will not hold guiltless those who misuse this sacred and relevant time for your family to worship God.

4 - Remember to make suitable preparations for your special family worship on the seventh day. The Lord your God has given you six days to worship him in the comfort of your own home and on the seventh day you should come together as a family to worship Him corporately with your fellow brothers and sisters in His Sanctuary. This special family worship ought not to be missed either by you, your wife, your son or daughter, your employees, or by those visitors in your place. For during six days you shall thank Him together with your family members for allowing you to contemplate and worship Him for all He has created and on the seventh-day you should do this with your fellow believers. Therefore, the Lord your God has blessed family worship and made it holy as He sanctified it for your whole family.

5 - Honor your daily family worship appointment with your heavenly Father with all your family, so that you may have a spiritual and happy family all the days of your life. 
6 - You shall not kill the family worship program because of your hurry, laziness, and/or earthly temporal commitments.

7 - You shall not adulterate your family worship with mundane ideas or music.

8 - You shall not steal the precious time of family worship from your children.

9 - You shall not bear false testimony before your children or fellow believers, including your pastor for not having family worship with your family.

10 - You shall not covet your fellow believers' family worship. You shall not copy their family worship program, ideas, illustration just for the sake of saving your time. You shall invest time praying and preparing your own program properly.

Have a blessed, creative, inspiring, "child - captivating" Family Worship! 
APPENDIX C:

Family Worship Seminar Work Sheet 


\section{Our Families for God}

A Family Worship Seminar

Pr. Wesley Torres

November 25, 2006

\section{Seminar Work Sheet - Section I}

\section{I - Definitions:}

a) Family: The biblical emphasis is on a family lineage that points to the and being One of much greater value (Matt. 23:9, John 8:41-42).

There are two purposes of the theology of the family: The first is that it is a necessary component of as it guarantees the continuity of the The second, as taught by ___ is that the family cannot be an end in itself, as it needs to enlarge its boundaries for others to come and join as the of God.

b) Worship: "Worship is joyful response to revelation."

Worship is "The wonder of the as he senses the presence of His

c) Family Worship: The most important purpose of Family Worship is to God. Family Worship is the surrendering of the to God!

\section{II - Why Worship God?}

a) $\mathrm{He}$ is our (Genesis 2:7).

b) $\mathrm{He}$ is the of our lives (Psalm 36:7, 9).

c) $\mathrm{He}$ is our in Jesus Christ (John 3:16-17.

d) It is our grateful and loving for God's goodness (I John 4:19).

e) Worship enhances our in God. It leads us to recognize our of God.

\section{III - What is Family Worship?}

a) Family Worship is a spiritual

b) Family Worship is a spiritual activity for the

c) Family Worship makes the religious that promotes for the families.

d) Family Worship is the field of applied of the family and

e) Family Worship is a "source of for the " that helps the family to stay as a

\section{IV - Biblical Examples of Family Worship:}

a) Before sin: Adam and Eve (couple) worshipped God (PP, 50)

b) After sin:

Who was he?

(Noah, Abraham, Jacob)

*"Wherever he pitched his tent, close beside it was set up his altar..."

Answer: . (PP, 128) 
*He built an altar for him and his family to worship God, even before building a house for himself.

Answer: . (Genesis 8:20)

*On his journey to Egypt, he gathered all his household around an altar to worship God and he offered sacrifices to God.

Answer: . (SDABC, $1: 466)$

c) The habit of the patriarchs in building concept of family worship. is an important element of the OT

d) Biblical figure mentioned by EGW as someone who was exposed to a careful religious instruction at home (Paul, Timothy, Barnabas, Apolo). (II Tim 1:5; 3:15)

Answer:

\title{
V - Jewish Tradition:
}

a) The ___ has always been the center of religious as their

b) Jewish families always referred to their was set aside for special purposes of the for the Jews.

c) The community needs. the , and as a place to

d) The acted like the , the learning of of his household and he ministered for his family.

\section{VI - Family Altar:}

a) Home - A for the family.

b) The "Family Altar" needs to be part of the family's

c) The father is the of the house.

d) The "Family Altar" should promote the of the

e) The "Family Altar" brings a taste of to the

See you in the afternoon for the remaining sections of the seminar.

Thank you for your participation.

\author{
Happy Sabbath!
}




\section{Our Families for God}

\section{A Family Worship Seminar}

Pr. Wesley Torres

November 25, 2006

Seminar Work Sheet - Section II

\section{I - Characteristics of Family Worship:}

1) It is a spiritual
a) It ought to promote the spiritual of the
b) It emphasizes the spiritual relationship b/t
c) It should take place in an atmosphere of
d) It is a fellowship time $b / t$ the and the family \& among the

and $\longrightarrow$. It $\longrightarrow$ and $\longrightarrow$ them with God.

2) FW is a
a) It should be conducted
b) It should be consistent and have a time.
c) It should take in the home.

3) FW needs to follow a
a) It needs to involve all
b) It is a time for
c) It shows a God of activity.

4) FW should be Christ -
a) Christ as the Savior and His
b) The presents Christ as the ministry in the heavenly
c) It highlights Christ's

5) Make it alive!
a) It should be brief and
b) It ought to be pleasant and
c) It is a , but a happy time.
d) It should be the , most helpful time of the
e) It God when it is dry and irksome.

\section{II - The Elements of Family Worship:}

a)

"Your Word is a lamp to my feet and a light to my path." Psalm 119:105.

b)

" is the life of the soul." "A family without is like a house without roof for protection."

c) to the Lord, praise His name; proclaim His salvation day after day." 
d) Storytelling.

“...simple stories may be made plain the great of God's law."

e) Personal testimonies.

"They should be They need to be from daily experiences in life.

III - Practical Suggestions for FW:

1) Make Bible study (reading) a . It should be personal, , , capitalize on spiritual

2) Prayer - Communicating with feelings of the be ; teach ; express the

3) A fulfilling lively time. It should be ; utilize visual ; short and ; allow the ; age to lead the

4) An amazing wisely; tell it, don't experience. Tell it as it it; be ; make practical use Storytelling involves a careful

5) Inspiring personal They should be ; drawn from experiences in life; how God has blessed the ; allow the to tell it. to pray. $\longrightarrow$

\section{IV - The JDI formula:}

$\mathrm{J}$

$\mathrm{D}$

I

See you in a few minutes for the third section of the seminar.

Thank you for your presence. 


\section{Our Families for God}

A Family Worship Seminar

Pr. Wesley Torres

November 25, 2006

\section{Seminar Work Sheet - Section III}

\section{I - Benefits of Family Worship:}

a) Family Worship promotes in the family.

b) Family Worship reminds the about their

c) Family Worship brings to the family about their spiritual

d) Family Worship invites the beings to join the family in to God.

\section{II - Suggestions for the Family Worship Program:}

1. Balance the elements of and of the program.

\section{Contents}

a) Failing to plan is to fail. Invest

b) Contents should be

c) Use adequate ; ; Instruments; ; age ; FW Length will determine the and

d) Contents deal with the

e) Use . Design the program.

\section{Length}

a) It should be to the family composition (adults, children, etc.)

b) Suitable for family members' (work, studies, etc).

c) . (plan 10, 15 minutes).

2. Time.

a) Before or after

b) At (Before going to bed, children, etc)

c) Find the most appropriate

d) Create the Morning and . (Whenever most family members are present).

3. Frequency.
a) Daily and
b) Home is our Follow the pattern of the Sanctuary.
c) Make it part of the family
d) It should be conducted besides our
e) "If you don't have personal devotions. , forget family \& evenings. the program. ; and of God. 
4. Place.
a) Breakfast
b) room; family room.
c) Parents or children's
b) ily Worship (room)

5. Order of the Program.
a) Praise. It should be
Lively to soft; Choruses or hymns.
b) Prayer. Reasons to thank God include: past
c) Story time. aids; good ; use ; day ahead; ; privilege to
d) Bible Study (reading) ; suitable
e) Testimonies. Concise; taken for granted. acknowledge their blessings the
f) Benediction. Short; ; arms around shoulders; hug. (Sense of touching \& feeling). God.
it, don't read it; connects with ; be creative!
g). Solemn part; should be held, studied ; appropriate ; personification; Let the Bible ; impacting! ; involving; the more people they are; Thank God for things usually ; -

6. Length. Morning: 10 - 15 minutes / Evening: 15-20 minutes (Suggestion).

7. Sabbath Family Worship. Make it a
a) Most interesting of the
b) It should create a sense of
c) prepared.
e) Prepares the family to meet fellow $\&$ at church.

\section{III - General Suggestions for FW leaders:}

a) Set the for FW. Consult w/ family members; it promotes the of FW.

b) $F$ members to _ \& in the the time. No external interference. $\mathrm{Ph} /$ answer machine.

c) Choose the best place in the

d) Create an atmosphere of joy \&

e) Organize the program. Leave room for the Quiet place!

f) Get all family members Let the Spirit inspire every heart to worship God.

g) Allow the children to

h) Be creative as you . It creates a sense of to make arrangements.

i) Be inclusive to all age or the FW. This helps them to feel valuable.

j) Do your best, your FW. New ideas, illustrations, music. God will bless! in your FW. It needs to be appealing to everyone. the rest with the

\section{IV - FW as a Witnessing Tool:}

a) Live your religious at home.

b) Exemplify your faith with your

c) Share your faith with your

See you in the last section of the seminar, shortly. 


\section{Our Families for God}

A Family Worship Seminar

Pr. Wesley Torres

November 25, 2006

Seminar Work Sheet - Section IV

\section{I - The When of Family Worship:}

1. "In and the mind is readi responsibility to teach their children about God.

a) It is the . Children learn what they see!

b) Teach by . Show them that the heavens are interested in their well being.

d) Spend home. time with your children. Enjoy their presence while they are still at

e) Make religion a . Fame \& money turns to dust; eternity with God - real gain!

2. Make religion attractive.

a) Help the children to be

b) Nothing "for . Count your blessings; talk about positive things. protection.

c) time preparing the $\mathrm{FW}$. Be creative; variety of activities; prepare materials. d) $\mathrm{Be} \_\&$ age appropriate Design a program to address your children's needs, age.

e) Involve them in the with them. \& participation. Sense of ownership. Become one

3. Introduce them to Christ.

a) Jesus is their

b) Jesus hears their

c) Jesus is their best Jesus.

d) Use simple \& direct . Children need to be taught that He died; loves \& cares for them. . Teach them to pray \& claim God's grace with confidence. . Promote a close, intimate, \& personal relationship with

e) $\mathrm{Be}$ Altar." ." Food; shelter; family; freedom; knowledge of God \& His 
2. Children enjoy changes \& surprises.
a) $\mathrm{Be}$ . Imagine yourself as a child. Choose a different place for $\mathrm{FW}$, once in a while.
b) Special . Sabbath dinner; nature walk; picnic; family member room (birthday).
c) your children. Decorate their room, special \& surprise family worship (b'day).

\section{III - Illustrations in Family Worship:}

\section{Illustration is worth 1,000 words!}

a) __ illustrations from life \& nature. Daily living; for story, praise, prayer, Bible reading.

b) Make them $\&$ . Objective; straight to point; easy to be grasped; spiritual.

c) topic. . Appealing; applicable for children's lives; immediate connection with the d) Age . Motivating; involving; understandable for their age; keep their interest.

2. The Bible is a visual Book.
a) God used illustrations. Passover; Ten Commandments; wilderness; Jesus, i.e., child.
b) ___ your own visual illustrations. FW Treasure box; use multimedia; design surprises.

\section{IV - The Ten Commandments of Family Worship:}

1. You shall have no other more important occasion at home than the time.

2. You shall make no excuses for bowing down every day before your , or . Although most of these are good things if properly used, they shall not compete with your family worship time in your

3. You shall not misuse family worship Lord will not hold guiltless those who misuse this family to worship God. by replacing it with anything else, for the and relevant time for your

4. to make suitable preparations for your special family worship on the seventh day. The Lord your God has given you six days to worship him in the comfort of your own and on the seventh day you should come together as a

corporately with your fellow brothers and sisters in His Sanctuary. This special ought not to be missed neither by you, your wife, your son or daughter, your employees, nor by those visitors in your place. For during six days you shall thank Him together with your family members for allowing you to contemplate and all He has created and on the seventh-day you should do this with your fellow believers. Therefore, the Lord your God has blessed family worship sanctified it for your whole family. and made it holy as $\mathrm{He}$ 
5. Honor your family worship appointment with your heavenly Father with all your , so that you may have a spiritual and happy family all the days of your life.

6. You shall not kill the family worship program because of your hurry, laziness, and/or earthly temporal

7. You shall not adulterate your family worship with mundane or music.

8. You shall not steal the time of family worship from your children.

9. You shall not bear false before your children or fellow believers, including your for not having family worship with your family.

10. You shall not your fellow believers' family worship. You shall not their family worship program, ideas, illustration just for the sake of your time. You shall invest time praying and preparing your own program properly.

Thank you for your presence and participation. I pray that it was a valuable and inspiring experience for you.

Please complete the evaluation form today.

Let us enjoy a light supper as we fellowship together. 
"Our Families for God"

Family Worship Seminar

Final Evaluation Survey

1. Gender

Male

Female

2. Age

Less than 20 years

Between $21-30$ years

$\square$

Between $31-45$ years

Between $46-60$ years

Over 61 years

3. The seminar was well organized \& structured

4. Clear language was used

5. The material presented was relevant

6. The contents were helpful

7. The seminar was an appropriate length

8. The seminar as a whole was practical

9. New ideas were introduced

Yes

Yes

Yes

Yes

Yes

Yes

Yes

Yes

Yes

Yes

No

No

No

No

No

No

10. Practical ideas were presented

No

11. It was of interest to children

12. Parents were challenged

No

No

No

13. Negative things about the Seminar.

14. Positive things about the Seminar.

15. General observations about the Seminar.

Thank you for your participation! 


\title{
Our Families for God
}

\author{
A Family Worship Seminar \\ Pr. Wesley Torres \\ November 25,2006
}

Seminar Work Sheet - Section I

\section{I - Definitions:}

a) Family: The biblical emphasis is on a family lineage that points to (God) as the head of the (family) and being One of much greater value (Matt. 23:9, John 8:41-42).

There are two purposes of the theology of the family: The first is that it is a necessary component of (creation) as it guarantees the continuity of the (human species). The second, as taught by (Christ), is that the family cannot be an end in itself, as it needs to enlarge its boundaries for others to come and join as the (family) of God.

b) Worship: "Worship is (man's) joyful response to (God's) revelation."

Worship is "The wonder of the (creature) as he senses the presence of His (reator)."

c) Family Worship: The most important purpose of Family Worship is to (worship) God.

Family Worship is the surrendering of the (family's heart) to God!

\section{II - Why Worship God?}

a) $\mathrm{He}$ is our (Creator) (Genesis 2:7).

b) $\mathrm{He}$ is the (sustainer) of our lives (Psalm 36:7,9).

c) $\mathrm{He}$ is our ( Savior) in Jesus Christ (John 3:16-17.

d) It is our grateful and loving (response) for God's goodness (I John 4:19).

e) Worship enhances our (faith) in God. It leads us to recognize our (dependence) of God.

\section{III - What is Family Worship?}

a) Family Worship is a spiritual (activity) that promotes (unit) for the families.

b) Family Worship is a spiritual activity for the (family).

c) Family Worship makes the religious (life) of the family (practical) and (alive).

d) Family Worship is the field of applied (religion) for the (family).

e) Family Worship is a "source of (spiritual strength)" that helps the family to stay as a unit.

\section{IV - Biblical Examples of Family Worship:}

a) Before sin: Adam and Eve (couple) worshipped God (face to face). (PP, 50)

b) After sin:

Who was he?

(Noah, Abraham, Jacob)

*"Wherever he pitched his tent, close beside it was set up his altar..."

Answer: (Abraham). (PP, 128) 
*He built an altar for him and his family to worship God, even before building a house for himself.

Answer: (Noah). (Genesis 8:20)

*On his journey to Egypt, he gathered all his household around an altar to worship God and he offered sacrifices to God.

Answer: (Jacob). (SDABC, 1:466)

c) The habit of the patriarchs in building (altars) is an important element of the OT concept of family worship.

d) Biblical figure mentioned by EGW as someone who was exposed to a careful religious instruction at home (Paul, Timothy, Barnabas, Apolo). (II Tim 1:5; 3:15) Answer: (Timothy).

V-Jewish Tradition:

a) The (home) has always been the center of religious (life) for the Jews.

b) Jewish families always referred to their (home) as their (sanctuaries).

c) The (home) was set aside for special purposes of the (worship of God), the learning of the (Torah), and as a place to (serve) community needs.

d) The (father) acted like the (priest) of his household and he ministered for his family.

\section{VI - Family Altar:}

a) Home - A ( Sanctuary) for the family.

b) The "Family Altar" needs to be part of the family's (daily plan).

c) The father is the (priest) of the house.

d) The "Family Altar" should promote the (study) of the (Bible).

e) The "Family Altar" brings a taste of (heaven) to the (family).

See you in the afternoon for the remaining sections of the seminar.

Thank you for your participation.

Happy Sabbath! 


\section{Our Families for God}

\section{A Family Worship Seminar}

Pr. Wesley Torres

November 25, 2006

\section{Seminar Work Sheet - Section II}

\section{I - Characteristics of Family Worship:}

1) It is a spiritual (activity).
a) It ought to promote the spiritual (growth) of the (family).
b) It emphasizes the spiritual relationship b/t ( $\underline{\mathrm{God}}$ ) and the family \& among the (members).
c) It should take place in an atmosphere of (peace), (harmony), (love), and (acceptance).
d) It is a fellowship time b/t the (family) and (God). It (connects) them with God.

2) FW is a (daily) activity.
a) It should be conducted (regularly).
b) It should be consistent and have a (fixed) time.
c) It should take (priority) in the home.

3) FW needs to follow a (structure).
a) It needs to involve all (participants).
b) It is a time for (teaching) and (communication).
c) It shows a God of (order) and a (Father) of love.

4) FW should be Christ - (centered).

a) Christ as the Savior and His (intercessory) ministry in the heavenly (Sanctuary).

b) The (Sabbath) presents Christ as the (reator).

c) It highlights Christ's (second coming).

5) Make it alive!

a) It should be brief and (full of life).

b) It ought to be pleasant and (interesting).

c) It is a (sacred), but a happy time.

d) It should be the (sweetest), most helpful time of the (day).

e) It (dishonors) God when it is dry and irksome.

\section{II - The Elements of Family Worship:}

a) (Bible study).

"Your Word is a lamp to my feet and a light to my path." Psalm 119:105.

b) (Prayer).

"(Prayer) is the life of the soul." "A family without (prayer) is like a house without roof for protection."

c) (Praise).

"(Sing) to the Lord, praise His name; proclaim His salvation day after day." 
d) Storytelling.

"...simple stories may be made plain the great (principles) of God's law."

e) Personal testimonies.

"They should be (practical), (short). They need to be (drawn) from daily experiences in life.

III - Practical Suggestions for FW:

1) Make Bible study (reading) a (pleasure). It should be (practical), personal, (relevant), (interesting), (attainable to children), capitalize on spiritual (lessons).

2) Prayer - Communicating with (God). It should have the feeling of (touch); express the feelings of the (heart); (spontaneous); be (creative); pray (reverently); teach (hildren) to pray.

3) A fulfilling (praise) time. It should be (uplifting); short and (attractive); age (appropriate); lively (experience); utilize visual (aids); allow the (children) to lead the (praise).

4) An amazing (storytelling) experience. Tell it as it (happened); make practical (applications); use (time) wisely; tell it, don't (read) it; be (creative); allow the (children) to tell it. Storytelling involves a careful (preparation).

5) Inspiring personal (testimonies). They should be (practical); (short); drawn from (daily) experiences in life; how God has blessed the (individual) or/and (family).

IV - The JDI formula:

$\mathrm{J}$ (ust)

$\mathrm{D}(\underline{\mathrm{o}})$

$I(t)$

See you in a few minutes for the third section of the seminar.

Thank you for your presence. 


\section{Our Families for God}

\section{A Family Worship Seminar \\ Pr. Wesley Torres}

November 25, 2006

\section{Seminar Work Sheet - Section III}

\section{I - Benefits of Family Worship:}

a) Family Worship promotes (unit) in the family.

b) Family Worship reminds the (family) about their (dependence) of God.

c) Family Worship brings (consciousness) to the family about their spiritual (life).

d) Family Worship invites the (heavenly) beings to join the family in (adoration) to God.

\section{II - Suggestions for the Family Worship Program:}

1. Balance the elements of (contents) and (length) of the program.

\section{Contents}

a) Failing to plan is (planning) to fail. Invest (time); (plan) the program.

b) Contents should be (relevant); (lively); (interesting); age (appropriate); and (spiritual).

c) Use adequate (resources). Instruments; (multimedia); FW (treasure box).

d) Contents deal with the (relevancy). Length will determine the (attention) and (interest).

e) Use (creativity). Design the program.

\section{Length}

a) It should be (realistic) to the family composition (adults, children, etc).

b) Suitable for family members' (schedules) (work, studies, etc).

c) (Consistency). (plan 10, 15 minutes).

2. Time.
a) Before or after (breakfast).
b) At (night). (Before going to bed, children, etc)
c) Find the most appropriate (time). (Whenever most family members are present).
d) Create the (habit). Morning and (evening).

3. Frequency.
a) Daily and (regularly).
b) Home is our (Sanctuary). Follow the pattern of the Sanctuary. (mornings \& evenings.
c) Make it part of the family (schedule).
d) It should be conducted besides our (personal) devotions.
e) "If you don't have personal (devotions), forget family (worship)." 
4. Place.
a) Breakfast (table).
b) (Living) room; family room.
c) Parents or children's (bedroom).
d) Family Worship (chamber). (room)

5. Order of the Program.
a) Praise. It should be (uplifting). Lively to soft; Choruses or hymns.
b) Prayer. Reasons to thank God include: past (night); day ahead; (family); (food); (shelter); (work); (studies); privilege to (worship) God.
c) Story time. (Moral) values books; devotional; (tell) it, don't read it; connects with (theme); use (visual) aids; good (illustration); be creative!
d) Bible Study (reading). Solemn part; should be held, studied (reverently); approp. (portion); suitable (translation); personification; Let the Bible (speak); impacting!
e) Testimonies. Concise; (personal); (practical); involving; the more people acknowledge their blessings the (happiest) they are; Thank God for things usually taken for granted.
f) Benediction. Short; (direct); random; (consecutively); join (hands); stand \& kneel in (circle); arms around shoulders; hug. (Sense of touching\& feeling).

6. Length. Morning: 10-15 minutes / Evening: 15-20 minutes (Suggestion).

7. Sabbath Family Worship. Make it a (celebration).
a) Most interesting of the (week).
b) It should create a sense of (expectation).
c) (Carefully) prepared.
d) It marks the beginning \& closing of the "(Lord's Day)."
e) Prepares the family to meet fellow (brothers) \& (sisters) at church.

\section{III - General Suggestions for FW leaders:}

a) Set the (time) for FW. Consult w/ family members; it promotes the (importance) of FW.

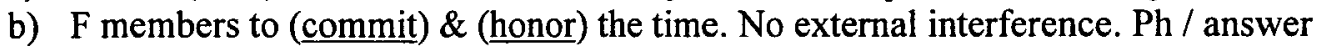
machine.

c) Choose the best place in the (house). Quiet place!

d) Create an atmosph. of joy \& (excitement). Let the Spirit inspire every heart to worship God.

e) Organize the program. Leave room for the (Holy Spirit) to make arrangements.

f) Get all family members (involved). It creates a sense of (belonging) \& (responsibility).

g) Allow the children to (plan) or (lead) the FW. This helps them to feel valuable.

h) Be creative as you (prepare) your FW. New ideas, illustrations, music. God will bless!

i) Be inclusive to all age (groups) in your FW. It needs to be appealing to everyone.

j) Do your best, (leave) the rest with the (Lord).

\section{IV - FW as a Witnessing Tool:}

a) Live your religious (principles) at home.

b) Exemplify your faith with your (relatives).

c) Share your faith with your (neighbors).

See you in the last section of the seminar, shortly. 


\section{Our Families for God}

\section{A Family Worship Seminar}

Pr. Wesley Torres

November 25, 2006

\section{Seminar Work Sheet - Section IV}

\section{I - The When of Family Worship:}

1. "In (childhood) the mind is readily impressed and molded, and it is then that (boys) and (girls) should be taught to (love) and honor God.'(AH, 486).

a) It is the (parents') responsibility to teach their children about God.

b) Teach by (example). Children learn what they see!

c) Pray for \& with your (children). Show them that the heavens are interested in their w. being.

d) Spend (quality) time with your children. Enjoy their presence while they are still at home.

e) Make religion a (priority). Fame \& money turns to dust; eternity with God - real gain!

2. Make religion attractive.

a) Help the children to be (grateful). Count your blessings; talk about positive things.

b) Nothing for (granted). Food; shelter; family; freedom; knowledge of God \& His protection.

c) (Invest) time preparing the FW. Be creative; variety of activities; prepare materials.

d) Be (accommodating) \& age approp. Design a progr. to address your children's needs, age.

e) Involve them in the (preparation) \& participation. Sense of ownership. Become one with them.

3. Introduce them to Christ.

a) Jesus is their ( $\underline{\text { Savior) }}$. Children need to be taught that He died; loves \& cares for them.

b) Jesus hears their (prayers). Teach them to pray \& claim God's grace with confidence.

c) Jesus is their best (friend). Promote a close, intimate, \& personal relationship with Jesus.

d) Use simple \& direct (language). Adapt the salvation message to their language level.

e) $\mathrm{Be}$ (consistent). Defined \& daily plan \& time for the children to meet Jesus - "Family Altar."

\section{II - The Where of Family Worship:}

1. Establish a regular place.

a) (Common) area (house). Breakf. table (M); liv. \& fam. room. Children need \& enjoy space.

b) Children's \& parents (bedroom). (E) Relaxed; friendly environment; less time pressure.

c) Encourage a FW (chamber). Reverence; consistency; proper environm.; materials' storage. 
2. Children enjoy changes \& surprises.

a) $\mathrm{Be}$ (creative). Imagine yourself as a child. Choose a different place for $\mathrm{FW}$, once in a while.

b) Special (occasions). Sabbath dinner; nature walk; picnic; family member room (birthday).

c) (Surprise) your children. Decorate their room, special \& surprise family worship (b'day).

\section{III - Illustrations in Family Worship:}

1. Illustration is worth 1,000 words!

a) (Simple) illustrations from life \& nature. Daily living; for story, praise, prayer, Bible reading.

b) Make them (real) \& (interesting). Objective; straight to point; easy to be grasped; spiritual.

c) (Practical). Appealing; applicable for children's lives; immediate connection with the topic.

d) Age (appropriate). Motivating; involving; understandable for their age; keep their interest.

2. The Bible is a visual Book.

a) God used (visual) illustrations. Passover; Ten Commandments; wilderness; Jesus, i.e., child.

b) (Prepare) your own visual illustrations. FW Treasure box; use multimedia; design surprises.

\section{IV - The Ten Commandments of Family Worship:}

1. You shall have no other more important occasion at home than the (family worship) time.

2. You shall make no excuses for bowing down every day before your (tw), (computer), (internet), or (video games). Although most of these are good things if properly used, they shall not compete with your family worship time in your (household).

3. You shall not misuse family worship (time) by replacing it with anything else, for the Lord will not hold guiltless those who misuse this (sacred) and relevant time for your family to worship God.

4. (Remember) to make suitable preparations for your special family worship on the seventh day. The Lord your God has given you six days to worship him in the comfort of your own (home) and on the seventh day you should come together as a (family) to worship Him corporately with your fellow brothers and sisters in His Sanctuary. This special ( worship) ought not to be missed neither by you, your wife, your son or daughter, your employees, nor by those visitors in your place. For during six days you shall thank Him together with your family members for allowing you to contemplate and (worship) Him for all He has created and on the seventh-day you should do this with your fellow believers. Therefore, the Lord your God has blessed family worship (time) and made it holy as $\mathrm{He}$ sanctified it for your whole family. 
5. Honor your (daily) family worship appointment with your heavenly Father with all your (family), so that you may have a spiritual and happy family all the days of your life.

6. You shall not kill the family worship program because of your hurry, laziness, and/or earthly temporal (

7. You shall not adulterate your family worship with mundane (ideas) or music.

8. You shall not steal the (precious) time of family worship from your children.

9. You shall not bear false (false testimonies) before your children or fellow believers, including your (pastor) for not having family worship with your family.

10. You shall not (covet) your fellow believers' family worship. You shall not (copy) their family worship program, ideas, illustration just for the sake of (saving) your time. You shall invest time praying and preparing your own program properly.

Thank you for your presence and participation.

I pray that it was a valuable and inspiring experience for you.

Please complete the evaluation form today.

Let us enjoy a light supper as we fellowship together. 
"Our Families for God"

Family Worship Seminar

Final Evaluation Survey

1. Gender

Male

Female

2. Age

Less than 20 years

$\square$

Between $21-30$ years

$\square$

Between $31-45$ years

$\square$

Between $46-60$ years

Over 61 years

3. The seminar was well organized \& structured

4. Clear language was used

Yes $\quad \square \quad$ No

Yes $\square \quad$ No

5. The material presented was relevant

Yes

Yes

Yes

7. The seminar was an appropriate length

Yes

8. The seminar as a whole was practical

Yes

10. Practical ideas were presented

Yes

Yes

11. It was of interest to children

12. Parents were challenged

Yes

No $\quad \square$

No $\square$

No $\square$

No $\square$

No $\square$

No $\square$

No $\square$

No $\square$

No $\square$

No $\square$.

13. Negative things about the Seminar.

14. Positive things about the Seminar.

15. General observations about the Seminar.

Thank you for your participation! 


\section{BIBLIOGRAPHY}

Adams, Jay E. Christian Living in the Home. Grand Rapids, MI: Baker, 1972.

Alexander, James W. Thoughts on Family Worship. Philadelphia, PA: Presbyterian Board of Education, 1847.

Anderson, Herbert. The Family and Pastoral Care. Philadelphia, PA: Fortress Press, 1984.

Ashgate Publishing. "Why a Picture Isn't Always Worth a Thousand Years." 2007. www.ashgate.com/subject_area/downloads/illustrations_guide.pdf(May 21, 2007).

Barnett, John C. A. Family Worship. London: Epworth Press, 1982.

Beach, W. M. "Family Worship." Review and Herald, 24 September 1970, 9.

Bradley, Mae C. "The Happiest Hour of the Day." Review and Herald, 13 December $1945,15$.

Burton, Laurel Arthur, ed. Religion and the Family: When God Helps. Bingham, NY: Haworth Pastoral Press, 1992.

"Came to Beer-sheba." Seventh-day Adventist Bible Commentary. Edited by Francis D. Nichol. Washington, DC: Review and Herald, 1953-57. 1:466.

Cameron, Richard Morgan. The Rise of Methodism. New York, NY: Philosophical Library, 1954.

Canada's Digital Collections. "Industrial Hamilton: A Trail to the Future." 2000. http://epe.lac-bac.gc.ca/100/205/301/ic/cdc/industrial/intro.htm (February 20, 2006).

Capps, Donald. Pastoral Counseling and Preaching. Philadelphia, PA: Westminster, 1980.

Clinebell, Howard J., ed. Pastor and Parish: A Systems Approach. Philadelphia, PA: Fortress, 1977.

Cobb, John B., Jr. Theology and Pastoral Care. Philadelphia, PA: Fortress, 1977.

Collins, Michael, and Matthew A. Price. The Story of Christianity. London: Dorling Kindersley, 1999. 
Comfort, Phillip. "Worship in the House Churches." In The Complete Library of Christian Worship. 2 Vols. Edited by Robert E. Webber, 1:157-158. Peabody, MA: Hendrickson Publishers, 1993.

Cox, Norman. "Why Have Family Worship?" Home Life, May 1947, 21.

Cramp, J. M. A Text Book of Popery: A Brief History of the Council of Trent. London: Houston and Stoneman, 1851.

Crider, Charles, and Robert C. Kristler. The Seventh-day Adventist Family: An Empirical Study. Berrien Springs, MI: Andrews University Press, 1979.

DeJong, Peter Y. "Calvin's Contribution to Christian Education." Calvin Theological Journal (November 1967): 200.

Delling, Gerhard. Worship in the New Testament. Philadelphia, PA: Westminster, 1962.

Dickerman, David Leslie. Family Worship in the Free-Church Tradition. D.Min. dissertation, Hartford Seminary, 1992.

Gangel, Kenneth O., and Warren S. Benson. Christian Education: Its History and Philosophy. Chicago, IL: Moody Press, 1983.

Gangel, Kenneth O., and James C. Wilhoit. The Christian Educator's Handbook on Spiritual Formation. Grand Rapids, MI: Baker, 1994.

Gebhard, Anna Laura, and Edward W. Gebhard. Guideposts to Creative Family Worship. Nashville, TN: Abingdon Press, 1959. . Our Family Worships at Home. Nashville, TN: Abingdon, 1958.

Gillespie, Joanna Bowen. "Episcopal: Family as the Nursery of Church and Society." In Faith Traditions \& the Family. Edited by Phyllis D. Airhart and Margareth Lamberts Bendroth. Louisville, KY: Westminster John Knox Press, 1996.

Gorsuch, Nancy J. Pastoral Visitation. Minneapolis, MN: Fortress, 1999.

Guernsey, Dennis. Sometimes It's Hard to Love God. Downers Grove, IL: InterVarsity, 1989.

Hambrick-Stowe, Charles E. The Practice of Piety: Puritan Devotional Disciplines in Seventeenth Century New England. Chapel Hill, NC: University of North Carolina Press, 1982.

Hamilton Spectator (Hamilton, Ontario), 4 October 1966.

Harnack, Adolf. Bible Reading in the Early Church. Translated by J. R. Wilkinson. London: Williams \& Norgate, 1912. 
Hatchett, Marion. Commentary on the American Prayer Book. New York, NY: Seabury Press, 1980.

Hayford Jack W. Worship His Majesty. Dallas, TX: Word Publishing, 1987.

Henderson, G. D. Religious Life in the Seventeenth-Century Scotland. London: Cambridge University Press, 1937.

Hertz, Joseph H., ed. A Book of Jewish Thoughts. New York: Oxford University Press, 1920.

Heynen, Ralph. The Secret of Christian Living. Grand Rapids, MI: Baker, 1966.

Hoon, Paul Waitman. The Integrity of Worship: Ecumenical and Pastoral Studies in Liturgical Theology. New York, NY: Abingdon Press, 1971.

“Incense Represents Blood of Atonement." Seventh-day Adventist Bible Commentary. Edited by Francis D. Nichol. Washington, DC: Review and Herald, 1953-57. 7:971.

Kemp, Charles F. The Caring Pastor. Nashville, TN: Abingdon, 1985.

Kuzma, Kay. Family Worship Binding Your Family Together for Now and Eternity. Redlands, CA: The Quiet Hour, 199-.

LaHaye, Tim. The Battle for the Family. Old Tappan, NJ: Revell, 1982.

Latourette, Kenneth Scott. Christianity Through the Ages. New York, NY: Harper, 1965. . A History of Christianity. 2 Vols. New York, NY: Harper, 1953.

Lee, Florence B. When Children Worship. Chicago, IL: Judson Press, 1963.

Lentz, Richard E. Christian Worship by Families. St. Louis, MO: Bethany Press, 1957.

Leonard, Bill J. "Southern Baptist: Family as Witness of Grace in the Community." In Faith Traditions \& the Family. Edited by Phyllis D. Airhart and Margareth Lamberts Bendroth. Louisville, KY: Westminster John Knox Press, 1996.

Leonard, Joe. Family Ministry. London: Scripture Union, 1988.

Lewis, A. J. Zinzendorf: The Ecumenical Pioneer. Philadelphia, PA: Westminster Press, 1962.

Lingle, Walter E. Presbyterians: Their History and Beliefs. Rev. ed. Richmond, VA: John Knox Press, 1960. 
Lyle, Bradford. Building Relationships Through Pastoral Visitation. Valley Forge, PA: Judson Press, 1984.

Mackay, John A. The Presbyterian Way of Life. Englewood Cliffs, NJ: Prentice-Hall, 1960.

Marsden, J. B. The History of the Early Puritans from the Reformation to the Civil War in 1642. London: Hamilton, Adams, and Sons, 1850.

Maxwell, William D. A History of Worship in the Church of Scotland. London: Oxford University Press, 1955.

McKee, Elsie Anne, trans. and ed. John Calvin Writings on Pastoral Piety. New York, NY: Paulist Press, 2001.

Motyer, J. A. "Idolatry." New Bible Dictionary. Edited by James D. Douglas. Wheaton, IL: Tyndale, 1992.

Moule, C. F. D. Worship in the New Testament. Richmond, VA: John Knox, 1961.

Myers, T. Cecil. Happiness Is Still Home Made. Waco, TX: Word Books, 1976.

Oates, Wayne E. The Presence of God in Pastoral Counseling. Waco, TX: Word, 1986.

Pelser, Frederick. Prayer Made Practical. Alma Park, Grantham, Lincolnshire, England: Autumn House, 1997.

Phillips, L. Edgel. An Explanatory Study of the Aims and Methods of Family Worship in the Seventh-day Adventist Church. Ph.D. dissertation, Andrews University, 1992.

Pierson, Robert H. So You Want to be a Leader. Hagerstown, MD: Review and Herald, 1996.

Pomerius, Julianus. The Contemplative Life. Translated by Mary Josephine Suelser. New York, NY: Newman Press, 1947.

Pourrat, P. Christian Spirituality. 4 Vols. Translated by W. H. Mitchell and S. P. Jacques. New York, NY: P. J. Kennedy and Sons, 1922.

Prewitt, J. David. "The Role of the Home in Christian Education." Church Training (December 1971): 22.

Prouty, Louise, Marion Case, and Nellie Ritchie, ed. Hamilton Mountain Seventh-day Adventist Church Memories, 100 th Anniversary 1889-1999. Photocopy.

Robinson, D. W. B. "Family Household." New Bible Dictionary. Edited by James D. Douglas. Wheaton, IL: Tyndale, 1992. 
"Sanctified them." Seventh-day Adventist Bible Commentary. Edited by Francis D. Nichol. Washington, DC: Review and Herald, 1953-57. 3:500.

Schaller, Lyle. The Pastor and the People. Nashville, TN: Abingdon, 1986.

Schalm, Bernard. The Church at Worship. Grand Rapids, MI: Baker, 1962.

Sheek, G. William. The Word on Families: A Biblical Guide to Family Well-Being. Nashville, TN: Abingdon, 1985.

Smith, C. Henry. The Story of the Mennonites. Newton, KS: Mennonite Publication Office, 1957.

Spalding, Arthur W. "The Family Altar." Our Homes, 3 April 1924, 11.

Stevens, Prescott. The Waldensian Story: A Study in Faith, Intolerance and Survival. Lewes, Sussex: The Book Guild, 1998.

Stone, Howard W. Crisis Counseling. Minneapolis, MN: Fortress, 1993.

Taylor, Robert. Christ in the Home. Grand Rapids, MI: Baker, 1973.

Thompson, G. B. "Family Worship." Review and Herald, 12 November 1914, 5.

Tourn, Giorgio. The Waldensians: The First 800 Years (1174-1974). Translated by Camilo P. Merlino. Torino, Italy: Claudian Beatrice, 1980.

Triola, Mario F. Elementary Statistics. $6^{\text {th }}$ ed. Reading, MA: Addison-Wesley Publishing Co., 1994.

Valenzuela, Alfonso. Como Fortalecer La Familia. Pasadena, CA: Living Ministry, 2005.

Warren, Rick. The Purpose Driven Life. Grand Rapids, MI: Zondervan, 2002.

Webber, Robert E., ed. The Complete Library of Christian Worship. Peabody, MA: Hendrickson Publishers, 1993. Worship Is a Verb. Waco, TX: Word Books, 1985.

Weeks, Louis B. To Be a Presbyterian. Atlanta, GA: John Knox Press, 1983.

White, Ellen Gould. Acts of the Apostles. Mountain View, CA: Pacific Press, 1997. . Adventist Home. Washington, DC: Review and Herald, 1952. . Child Guidance. Hagerstown, MD: Review and Herald, 1997. . Christian Service. Washington, DC: Review and Herald, 1983. 
. Christ's Object Lesson. Washington, DC: Review and Herald, 1952.

. Counsels to Parents, Teachers, and Students. Mountain View, CA: Pacific

Press, 1943.

. Desire of Ages. Mountain View, CA: Pacific Press, 1940.

. Education. Mountain View, CA: Pacific Press, 1952.

. Evangelism. Washington, DC: Review and Herald, 1974.

. Fundamentals of Christian Education. Nashville, TN: Southern Publishing Assn., 1923.

. Gospel Workers. Washington, DC: Review and Herald, 1915.

. Great Controversy. Mountain View, CA: Pacific Press, 1950.

. Letter to Brethren, 24 June 1900. Letter 91, 1900. Center for Adventist

Research. Andrews University, Berrien Springs, MI.

. Messages to Young People. Washington, DC: Review and Herald, 1930.

. Ministry of Healing. Mountain View, CA: Pacific Press, 1942.

. MS 19, 1900. Center for Adventist Research. Andrews University, Berrien Springs, MI.

. My Life Today. Hagerstown, MD: Review and Herald, 1980.

. Patriarchs and Prophets. Mountain View, CA: Pacific Press, 1958.

. Selected Messages. 3 Vols. Washington, DC: Review and Herald, 1958.

. Spiritual Gifts. 4 Vols. Washington, DC: Review and Herald, 1945.

. Steps to Christ. Mountain View, CA: Pacific Press, 1956.

. Testimonies for the Church. 9 Vols. Mountain View, CA: Pacific Press, 1948.

Wikipedia. "Hamilton, Ontario." 17 May 2007. http://en.wikipedia.org/wiki/ Hamilton,_Ontario (February 20, 2006).

Wilkinson, Charles. “Adventists Open Seniors' Centre." Hamilton Spectator (Hamilton, Ontario), 28 August 1982.

Williams, Norman V. How to Have a Family Altar. Chicago, IL: Moody Press, 1951.

Wilson, Marvin R. Our Father Abraham. Grand Rapids, MI: Eerdmans, 1994. 
Wood, C. A. "Family Worship." Advent Review and Sabbath Herald, 14 May 1931, 19.

The Works of John Wesley. Vol. 20. London: Wesley-Methodist Book Room, n.d.

Wornow, Beatrice. "Building Altars." Review and Herald, 24 May 1956, 12.

Youngberg, John, and Millie Youngberg. Heart Tuning: A Guide to a Better Family Worship. Hagerstown, MD: Review and Herald, 1985.

Zinner, Dirk, ed. 100 Years of Adventism in Ontario. Ottawa, ON: Tri-Co Printing Inc., 1999. 


\section{VITA}

Name: Wesley Rocha Torres

Date of Birth: April 14, 1961

Place of Birth: Belo Horizonte, MG, Brazil

\section{Education}

Instituto Adventista de Ensino (Brazil College), B.A. 1984

Andrews University, M.A.

Andrews University, D.Min.

\section{Work Experience}

Church Pastor
Church Pastor
$\begin{array}{r}\text { Conf. Youth Director } \\ \text { \& Church Pastor }\end{array}$
Church Pastor
Church Pastor
Church Pastor
Church Pastor
Youth Pastor
Church Pastor

Bandeirantes District

Belo Horizonte, MG, Brazil

1985-1987

Vitoria Central Church

Vitoria, ES, Brazil

1988

Planalto District

Belo Horizonte, MG, Brazil 1989

Framingham Church

Frammingham, Massachussets

The Hill Portuguese Church

Johannesburg, South Africa

Ashfield Portuguese Church

Sydney, NSW, Australia

Concord Church (English)

Sydney, NSW, Australia

Sydney Central Region

Sydney, NSW, Australia

1990

1991-1995

1995-2002

Hamilton Mountain Church

Hamilton, Ontario, Canada

2001-2002

2000-2002

2003- 